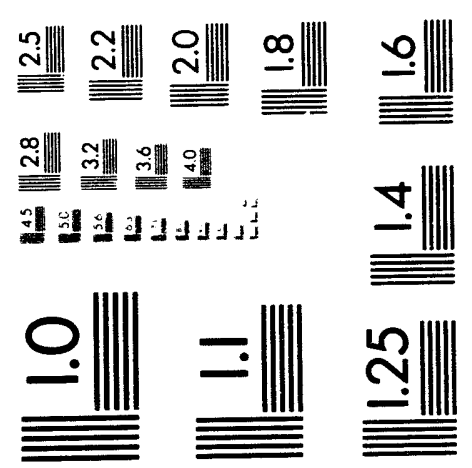



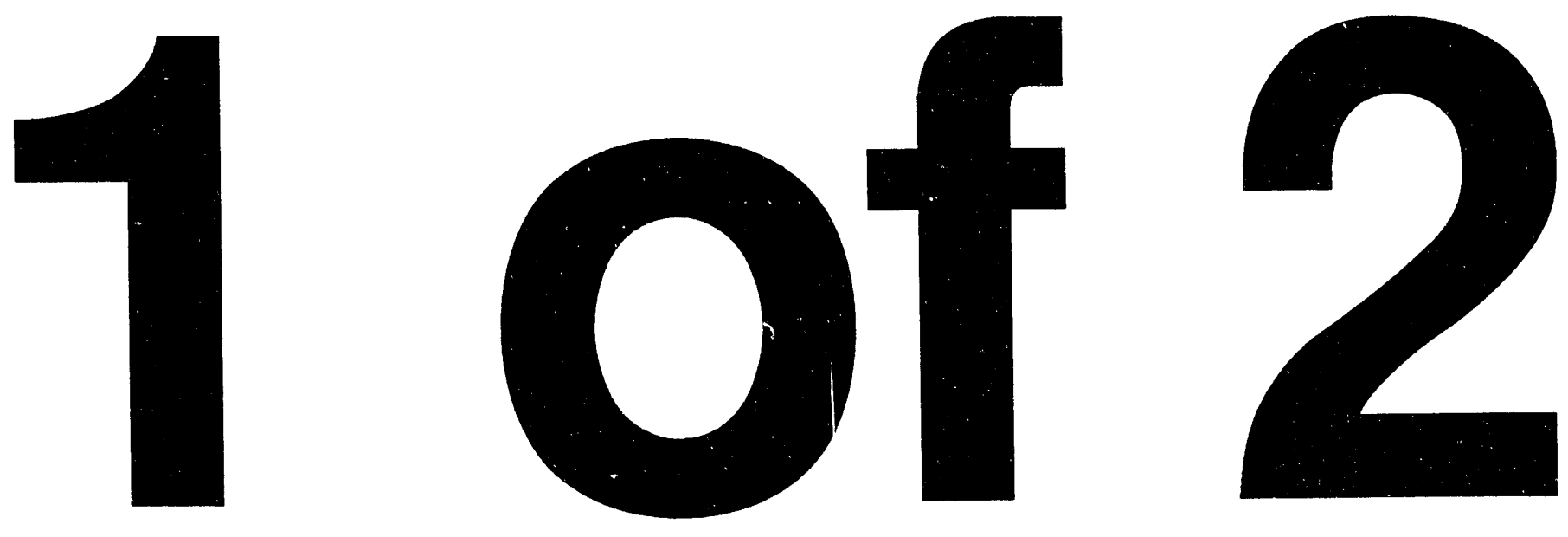


\section{Wetland Mitigation Banking for the Oil and Gas Industry: Assessment, Conclusions, and Recommendations}

by P.L. Wilkey, R.C. Sundell, K.A. Bailey, and D.C. Hayes

Reclamation Engineering and Geosciences Section, Energy Systems Division, Argonne National Laboratory, 9700 South Cass Avenue, Argonne, Illinois 60439

January 1994

Work sponsored by Gas Research Institute, American Petroleum Institute,

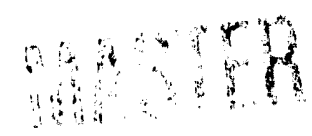
Interstate Natural Gas Association of Americic Foundation, and United States Department of Energy, Assistant Secretary for Fossil Energy 


\section{Contents}

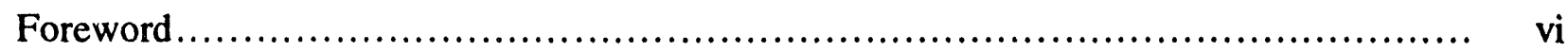

Acknowledgments............................................................ viii

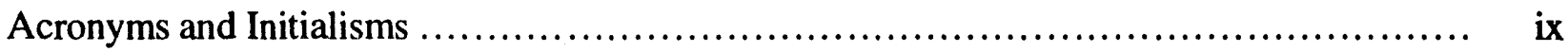

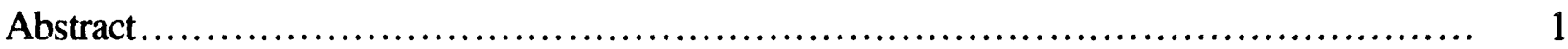

1 Introduction ................................................................ 1

1.1 Values and Functions of Wetlands......................................... 2

1.2 Losses of Wetlands......................................................... 2

1.3 Wetland Mitigation Policies and Future Trends................................. 3

1.4 Project Objectives and Approach.......................................... 4

2 Wetland Banking Concepts and Terminology ................................. 6

2.1 Bank-Specific Definitions and Terms ................................. 7

2.1.1 Wetlands - Regulatory Definition vs. Project Definition............... 7

2.1.2 Off-Site Wetland Mitigation Methods ................................ 8

2.1.3 $\begin{aligned} & \text { Wetland Mitigation Banking - Regulatory } \\ & \text { Definition vs. Project Definition ....................................... } 8\end{aligned}$

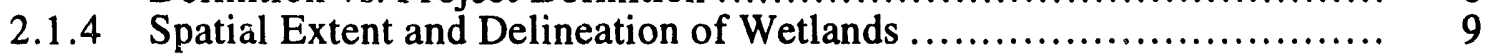

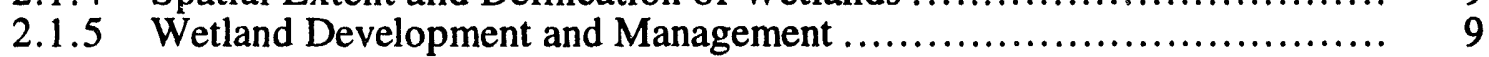

2.1.6 Wetland Processes — Function vs. Value ........................... 10

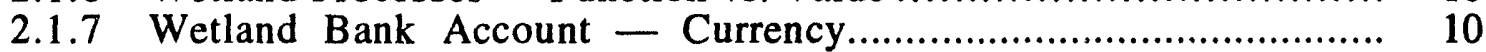

2.1.8 Wetland Bank Account - Debits and Credits ......................... 10

2.1.9 Off-Site Mitigation Type - A Priori, Concurrent Credit Use, and In Lieu Fee Arrangements......................................... 11

2.1.10 Wetland Banking Risk Categories ................................... 14

2.2 General Wetland Definitions and Terms................................... 16

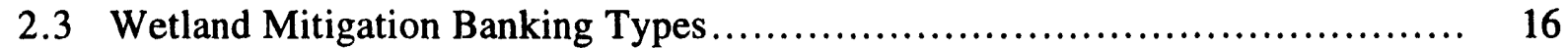

2.3.1 Public Agency Owner/Public User Bank ............................ 16

2.3.2 Single Private Owner/Single Private User Bank ..................... 18

2.3.3 Single Private Owner/Multiple Private and Public User Bank............ 18

3 Evaluation of Major Wetland Banking Factors ................................. 19

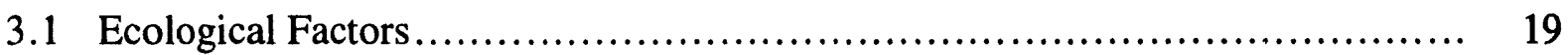

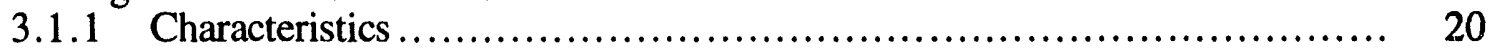

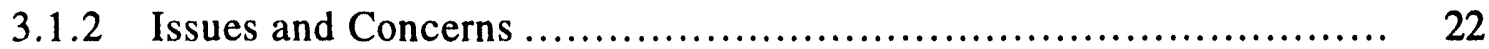

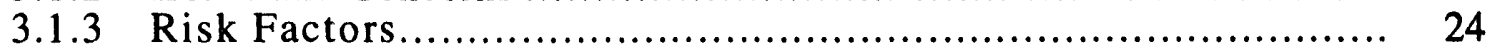

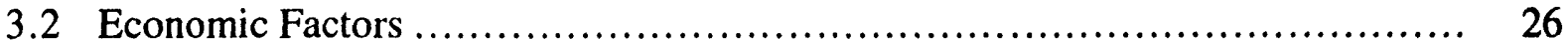

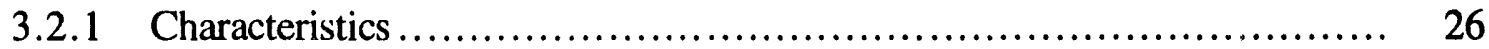

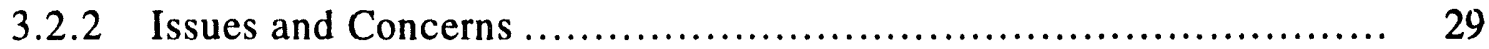

3.2.3 Risk Factors...................................................... 34

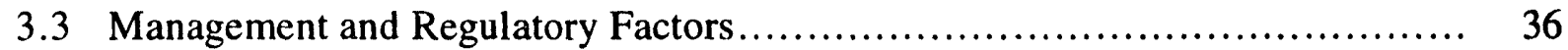

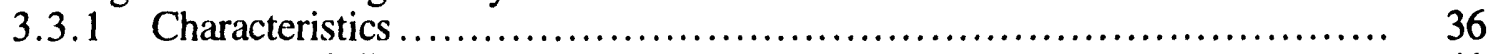

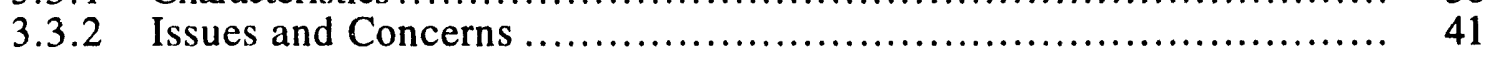

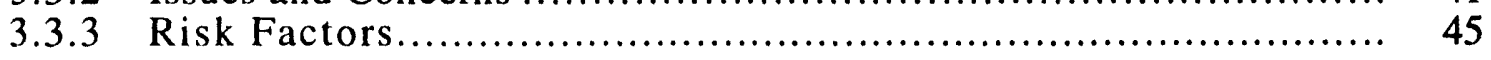




\section{Contents (Cont.)}

4 Cost Considerations of Current Mitigation Practices and Wetland Banking......... 47

4.1 Costs of Current Oil and Gas Mitigation Practices........................... 47

4.2 Documented and Anticipated Mitigation Banking Costs ........................ 48

4.3 Cost Comparisons and Related Issues..................................... 48

4.4 Wetland Mitigation Banking Project Evaluation ............................ 50

4.4.1 Evaluation of Public and Private Wetland Mitigation Banking ........... 51

4.4.2 Treatment of Risk in the Evaluation of a Development ................ 58

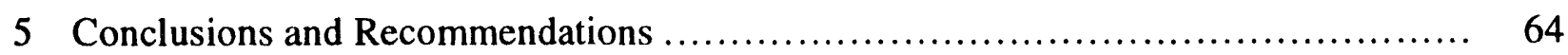

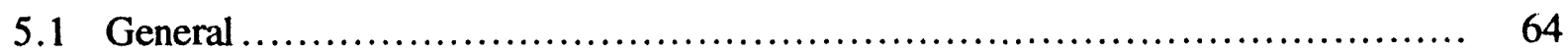

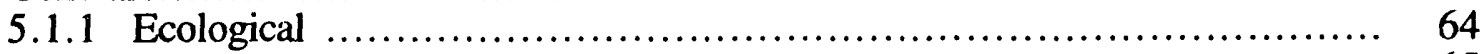

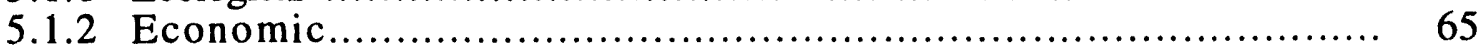

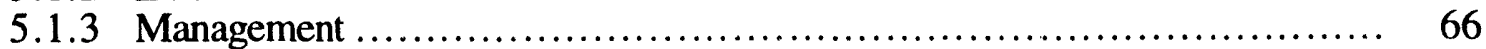

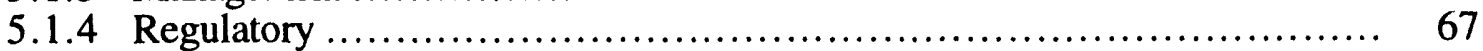

5.2 Evaluation Criteria for Decision Making ..................................... 68

5.2.1 Is Wetland Mitigation Banking Permissible? .......................... 68

5.2.2 Is Wetland Mitigation Banking Technically and

Ecologically Feasible? ............................................... 70

5.2.3 Is Wetland Mitigation Banking Economically Feasible?............... 70

5.2.4 Is the Banking Concept Being Promoted by Any Special

Circumstances?....................................................... 71

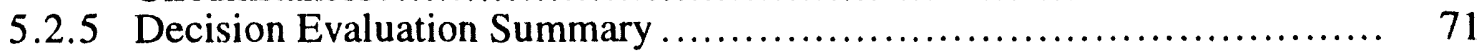

5.3 Recommendations for Future Work ..................................... 72

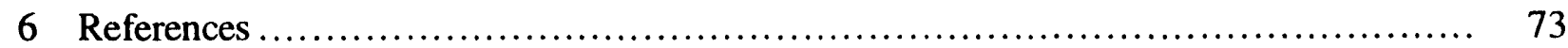

Appendix A: Wetland Mitigation Banking Definitions and Terms.................... 77

Appendix B: Summary of Wetland Mitigation Bank Characteristics................ 105

Appendix C: Summary of Current Wetland Mitigation Costs....................... 133

\section{Figures}

2.1 Temporal Loss of Wetland Values: A Priori Mitigation Banking................. 12

2.2 Temporal Loss of Wetland Values: Concurrent Mitigation Project .............. 13

2.3 Temporal Loss of Wetland Values: In Lieu Fee Project ...................... 15

3.1 Mitigation Banking Timeline ............................................. 35

4.1 Break-Even Analysis Assuming Variable Revenue................................ 60

4.2 Break-Even Analysis Assuming Variable Maintenance Cost ................. 61 


\section{Tables}

2.1 Manager/Owner and User Relationships of Existing Mitigation Bank Sites......... 17

3.1 Wetland Mitigation Banks Visited by ANL S aff................................ 19

4.1 Characterization of the Surveyed Banks ..................................... 49

4.2 Comparison of Cost, Risk, and Evaluation Considerations for Private vs. Public Banks ................................................... 52

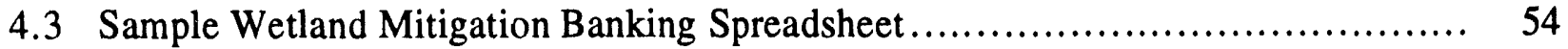

4.4 Sample Wetland Mitigation Banking Spreadsheet Including Representative Cash Flows and Costs........................................................ 62

4.5 Sample Evaluation Spreadsheet with Representative Cash Flows and Variations in Costs......................................................... 63

5.1 Decision Components for Mitigation Banking .............................. 69

C. 1 Summary of Current Wetland Mitigation Costs................................ 137 


\section{Foreword}

Wetland mitigation banks are already in existence in the United States, and the number is increasing. To date, most of these banks have been created and operated for mitigation of impacts arising from highway or commercial development and have not been associated with the oil and gas industry. Argonne National Laboratory evaluated the current status and effectiveness of wetland mitigation banking as a mitigation option for the oil and gas industry by examining banks already created for other uses by federal, state, and private entities. Specific issues addressed in this study include (1) the economic, ecological, and technical effectiveness of existing banks; (2) the changing nature of local, state, and federal jurisdiction; and (3) the unique regulatory and jurisdictional problems affecting bank developments associated with the oil and gas industry.

Fifty existing and planned mitigation banks were characterized from the perspectives of technical parameters, jurisdiction and regulations, management, monitoring, and banking procedures. Thirteen banks were chosen for site visits and in-depth interviews with site managers and regulators. A set of definitions for wetland mitigation banking was established early in the project through technical review of federal and state agency manuals. A literature survey of wetland mitigation banking included all published articles and studies in progress by other organizations. All current state wetland banking policies and regulations concerning wetland mitigation banking were reviewed through telephone interviews and follow-up written surveys. A common basis for economic cost comparison between mitigation banking and conventional mitigation techniques was developed by using information provided by the private mitigation banks.

The evaluation yielded the following results:

- Only a priori banks fit the definition of wetland mitigation banking established for this research. Concurrent credit use and in lieu fee programs are distinct from true banks. Banks and banking transactions must be treated independently from the Section 404(b)(1) permit sequencing in order to be viable.

- As a practical matter under the present regulatory climate, banking transactions may need to be limited to exchanges involving comparable wetland functions within drainage basins and ecoregions. Wetlands being used as banks should not be limited in their credit or acreage to only the area occupied by jurisdictional wetlands.

- Currency may be established on the basis of wetland functions, wetland values, regional wetland needs, acreage, and habitat value. Banking programs that have fully developed and agreed-upon systems of currency, transactions, and management are less dependent on mitigation ratios. 
- Banks should be planned on the basis of modest goals for wetland functions. Higher-order functions (e.g., preserving endangered species habitat) are difficult to justify for economic or currency purposes if the uncertainty in achieving those functions is high.

- Wetland values in a mitigation bank do not need to be fully developed to initiate credit use. Management of banks must be maintained in perpetuity, until natural processes are projected to diminish or deplete the value of the wetland, or until the wetland becomes self-sustaining.

- A standard memorandum of agreement (MOA) for the creation of a bank must be developed and implemented for as many jurisdictional levels as possible. Because some banks may take decades to achieve their full levels of functions and values, MOAs must include management strategies to achieve these levels over time. The effectiveness of individual banks can be determined on the basis of the achievement of the ecological, economic, and management goals identified in the MOA.

This report presents an important attempt to clarify key issues associated with implementing wetland mitigation banking as a policy option. In using this report, several critical points should be emphasized. First, wetland mitigation banking is not suggested as a replacement for conventional mitigation approaches, but only as an additional option. Second, the narrow definition of wetland mitigation banking presented by the investigators as including only a priori mitigation is not consistent with all definitions of wetland mitigation banking. Third, the efficacy of such other "banking" approaches as in lieu fee programs and concurrent mitigation credit systems is not disputed by this report. Fourth, the views presented in the report reflect those of the investigators and not the sponsoring organizations, as discussed in the report disclaimer.

Ted A. Williams

GRI Project Manager

Environment and Safety Research Department 


\section{Acknowledgments}

This report on wetland mitigation banking was funded by the Gas Research Institute, the American Petroleum Institute, the Interstate Natural Gas Association of America Foundation, and the U.S. Department of Energy. Thanks go to many members of those organizations for their reviews and comments. Special thanks go to $\mathrm{H}$. Ronald Isaacson, GRI; Robert DeCaprio, API; Ted Kinne, INGAAF; and Dr. Brent W. Smith, DOE, for conceiving this program and providing their guidance. The GRI project manager, Ted Williams, furnished guidance and support, and his interest and assistance are especially appreciated. We also appreciate Robin Lewis's assistance in arranging site visits and his insights into wetland restoration.

Special thanks go to the numerous other individuals within the state and federal government regulatory agencies and in private industry who cooperated by filling out surveys, supplying information, or agreeing to be interviewed. 


\section{Acronyms and Initialisms}

$\begin{array}{ll}\text { ANL } & \text { Argonne National Laboratory } \\ \text { API } & \text { American Petroleum Institute } \\ \text { CCC } & \text { California Coastal Conservancy } \\ \text { CFR } & \text { Code of Federal Regulations } \\ \text { CWA } & \text { Clean Water Act } \\ \text { DNR } & \text { Department of Natural Resources } \\ \text { DOE } & \text { Department of Energy } \\ \text { DOT } & \text { Department of Transportation } \\ \text { FICWD } & \text { Federal Interagency Committee for Wetland Delineation } \\ \text { GRI } & \text { Gas Research Institute } \\ \text { HEP } & \text { Habitat Evaluation Procedure } \\ \text { INGAAF } & \text { Interstate Natural Gas Association of America Foundation } \\ \text { MnDOT } & \text { Minnesota Department of Transportation } \\ \text { MOA } & \text { Memorandum of Agreement } \\ \text { MOU } & \text { Memorandum of Understanding } \\ \text { NMFS } & \text { National Marine Fisheries Service } \\ \text { NPV } & \text { Net present value } \\ \text { USACOE } & \text { U.S. Army Corps of Engineers } \\ \text { USEPA } & \text { U.S. Environmental Protection Agency } \\ \text { USFWS } & \text { U.S. Fish and Wildlife Service } \\ \text { USSCS } & \text { U.S. Soil and Conservation Service } \\ \text { WET } & \text { Wetland Evaluation Technique }\end{array}$




\title{
Wetland Mitigation Banking for the OII and Gas Industry: Assessment, Conclusions, and Recommendations
}

by

\author{
P.L. Wilkey, R.C. Sundell, K.A. Bailey, and D.C. Hayes
}

\begin{abstract}
Wetland mitigation banks are already in existence in the United States, and the number is increasing. To date, most of these banks have been created and operated for mitigation of impacts arising from highway or commercial development and have not been associated with the oil and gas industry. Argonne National Laboratory evaluated the positive and negative aspects of wetland mitigation banking for the oil and gas industry by examining banks already created for other uses by federal, state, and private entities. Specific issues addressed in this study include (1) the economic, ecological, and technical effectiveness of existing banks; (2) the changing nature of local, state, and federal jurisdiction; and (3) the unique regulatory and jurisdictional problems affecting bank developments associated with the oil and gas industry.
\end{abstract}

\section{Introduction}

Mitigating the environmental impacts on wetland ecosystems of oil and gas exploration, production, and transportation is a critical issue in the development of national oil and gas resources. One option for impact mitigation under well-defined circumstances is wetland banking. With this process, credits are provided or wetland acreage is created, enhanced, restored, or set aside to compensate for those areas affected by development operations. Numerous agencies at the state and federal level are investigating the banking option from the perspective of the sponsoring agency. Industrial and private entrepreneurs are also investigating banking as a cost-effective way of meeting their mitigation responsibilities. In this report, the concept of wetland mitigation banking and its implications for the oil and gas industry are evaluated by Argonne National Laboratory (ANL).

This wetland mitigation banking project was sponsored by the Gas Research Institute (GRI), the American Petroleum Institute (API), the Interstate Natural Gas Association of America Foundation (INGAAF), and the U.S. Department of Energy (DOE), All four organizations sponsor and administer research programs related to oil and gas resource development. 


\subsection{Values and Functions of Wetlands}

Wetlands have been historically thought of as low-value land that should be drained and made productive. In reality, these areas have many functions vital to the local, regional, and global biological cycles. The most visible function of wetlands is as wildlife habitat. Although the wetlands make up less than $6 \%$ of the land area of the earth, they shelter a much greater percentage of wildlife species. Many wetlands qualify as critical habitats under the Endangered Species Act, in which $26 \%$ of the plants and $45 \%$ of the animals listed as threatened or endangered are somewhat dependent on wetlands (Hammer 1992). The dynamic nature of wetlands, with daily, seasonal, and yearly inundation and drying cycles, includes differing plant compositions, water depths, and temperature gradients. These factors create a myriad of riches to benefit an incredibly diverse wildlife. A by-product of the rich habitat for bird and wildlife species is the potential recreational use. Wetlands can be enjoyed by the sport hunter and angler, as well as the photographer, hiker, botanist, and bird watcher. The economic value of recreational use of wetlands is directly linked to wetland health. Commercial hunters and fishermen also note that these same characteristics make wetlands valuable from an economic standpoint. The declining populations of economic species of fish, shellfish, birds, reptiles and fur-bearing animals, which depend on wetlands during most or part of their lives, is a direct function of wetland loss (Hammer 1992).

Wetlands play a valuable role in stabilizing shorelines and providing protection from erosive tides, storms, and winds. They provide natural flood control or buffering for downstream areas by slowing floodwater; they act as a groundwater recharge area and as reservoirs during dry periods. The effect of reducing riparian wetland areas in the process of channelizing rivers was seen in the devastating flooding along the Mississippi and Missouri Rivers in the stmmer of 1993. In addition, wetlands act as an efficient filter for many forms of point-source and nonpoint-source water pollution by means of biological and physical filtration, sedimentation, and other processes. Many organic pollutants (e.g., fertilizers) can be assimilated by wetland plants and recycled into biomass. Wetland plants can also remove many of the chemicals found in mine drainage, such as iron and manganese.

\subsection{Losses of Wetlands}

Wetlands are being lost and gained continually through such natural processes as the growth and decay of a river delta. However, because of human intervention, wetland losses have accelerated. Losses include both areal extent and ecological function lost by filling or excavation; changes in drainage patterns, temperature, and salt levels; reduction in the water source; and massive pollution. The largest percentage of loss is occurring through drainage of freshwater inland wetlands by agricultural conversion, which has increased dramatically since 1890) (Gosselink and Maltby 1990).

Historic causes of coastal-wetland loss include direct conversion by agricultural and urban expansion, canals and spoil banks, navigation projects (on the Mississippi), and intensive oil and 
gas exploration and extraction. In upstream flood-control projects, the sediment losses in the delta regions are not being replaced, resulting in subsidence and loss of deltaic marsh vegetation (Turner and Cahoon 1988). However, overall losses of U.S. coastal wetlands, in general, have decreased since the 1970s (Britsch and Kemp 1990).

\subsection{Wetland Mitigation Policies and Future Trends}

In 1988, the National Wetlands Policy Forum recommended that the nation establish a national wetlands protection policy to achieve no overall net loss of the remaining wetlands base, as defined by acreage and function, and to restore and create wetlands, where feasible, to increase the quality and quantity of the wetlands resource base. Former President Bush's affirmation and President Clinton's acceptance of this policy as a national goal focused considerable attention on improvement of wetlands protection through the Section 404 dredge and fill permit program of the Clean Water Act (CWA). Section 404 requires that adverse ecological impacts of development in wetlands be mitigated. President Clinton has specifically endorsed the use of mitigation banking to help attain the goal of no overall net loss, and regulatory agencies are suggesting wetland mitigation banking as a means of satisfying the Section 404 requirements (White House Office on Environmental Policy 1993). Many state and federal agencies consider banking to be an effective method of mitigating off-site wetland impacts. Several state banking programs exist, although their definitions of banking vary from those in the White House policy statements. The banking process offers a unique wetland mitigation approach because mitigation is completed before the construction process is initiated, rather than at the end of the project; this approach reduces costly project time delays and ensures that the mitigation is successful.

In wetland mitigation banking, unavoidable wetland losses are compensated by credits from a preestablished wetland. This approach differs from the other off-site mitigation strategies, such as concurrent credit use or in lieu fee programs where mitigation takes place at the same time as or after the impact. This process offers several benefits. First, the banking of credits before actual need can expedite the permitting process and reduce regulatory risks associated with mitigation. Second, cost savings can result due to the economies of scale associated with larger mitigation-system wetland developments. Third, placement and management of banking developments as part of a larger ecosystem can provide greater benefits for wildlife; smaller mitigation projects are often isolated, with little opportunity for enhancement of wildlife or fisheries. Finally, uncertainty concerning the long-term stability and effectiveness of mitigation actions is reduced, due to the use of established wetlands. Potential wetland banks would include drained or degraded wetlands having a high probability of being restored to their original hydrologic patterns. The creation of new wetlands is also an option, but there is less assurance of success, because of the difficulties in establishing and maintaining the appropriate hydrologic regime. Preservation of existing wetlands may also be an option under defined or exceptional circumstances (White House Office on Environmental Policy 1993; U.S. Environmental Protection Agency and DOE 1993).

Wetland mitigation banking can assist the oil and gas industry in efficient development of an energy source while protecting the environment. The usefulness of this strategy for energy 
transportation projects is less certain and will depend on how the policy develops. Where wetland mitigation banking is allowed, the energy industry will benefit from a more expeditious permitting process, lower wetland mitigation costs, and an increase in the probability of effectiveness in mitigation efforts. The environment will benefit by the establishment of large-scale wetland systems that provide diverse and stable habitats for animals and plants. In addition, the federal policy of no overall net loss of wetlands will be furthered by the long-term protection of wetland resources afforded by the banking process. The Clinton administration has endorsed wetland banking as an option, and it will be included as part of future federal policy for wetlands protection.

\subsection{Project Objectives and Approach}

There are four major objectives of the ANL Wetland Mitigation Banking Research Project. These objectives are to

1. Examine the administrative, technical, and economic feasibility of the concept of mitigation banking for the oil and gas industry;

2. Develop guidance procedures for implementing the banking process;

3. Conduct research into operating a mitigation bank and implement this research in a field-test mitigation bank; and

4. Evaluate the technical effectiveness of the field-test mitigation bank.

Phase 1 (funded) encompasses the first two objectives, while the latter two objectives will be dealt with in Phase 2 of the program (currently unfunded). The results described in this report address the first objective and establish the baseline decisions necessary in addressing the second objective.

The primary goal of Phase 1 was evaluation of the practicality and usefulness of wetland mitigation banking to the oil and gas industry. The research was divided into four evaluation tasks. The following paragraphs briefly describe the tasks, the approach taken to accomplish the tasks, and the sections of this report describing the results.

In the first task, a literature review of existing data on wetland mitigation practices was compiled, along with data ANL developed in the course of this research. Summary reports from numerous agencies and support contractors were identified, gathered into a single data file, and used in the development of this research. Some of the studies available at the time included reports from the Environmental Law Institute (1993), the World Wildlife Fund (1990), the U.S. Army Corps of Engineers (USACOE) (Reppert 1992, Eggers 1992), and the U.S. Fish and Wildlife Service (USFWS) (Short 1988). Section 2 and Appendix A of this report contain detailed 
descriptions of terminology associated with wetland mitigation banking. Published glossaries provided the definitions for key terms. Federal and state agencies provided regulations and associated terminology for review. Both general and banking-specific definitions and, where warranted, program-specific definitions were developed. The regulatory framework was evaluated on the federal and state levels. Regulations were evaluated, with respect to both wetland mitigation in general and wetland mitigation banking specifically, for the feasibility of applying the banking concept on a national basis.

In the second task, the existing wetland mitigation banks were characterized. On the basis of the information gathered in Task 1, a standardized format was designed that simplified the collection and recording of detailed information on the wetland mitigation banks. Information gathered included size, location, ecological description, management, regulatory issues, long-term management, currency, and geographic scope of the banks. Not all the information requested was available for every bank. The ecological, econo...ic, and management'iegulatory attributes of the existing banks are presented throughout the evaluation section (Section 3) of this report and in Appendix B.

In the third task, the regulatory and biological effectiveness of the existing banks was evaluated on the basis of the information gathered in Task 2 and from detailed site visits to representative banks across the country. The banks selected for visits have end-users or operators similar to those in the oil and gas industry and provide reasonably broad geographical and ecological perspectives. Ecological effectiveness of the representative banks was assessed during the site visits. In-depth discussions with banking participants identified both regulatory and management effectiveness and failures. The standardized format for gathering data was used in on-site interviews to achieve the highest level of detail. The information from these site visits is also found throughout Section 3 and Appendix B.

In the fourth task of Phase 1, costs for wetland mitigation banking were compared with those for on-site mitigation by using information collected in Tasks 1 through 3 . These costs were determined from both the actual bank costs and the costs associated with the currency of choice at the bank. A survey of 20 pipeline companies provided cost data associated with current on-site wetland mitigation for 24 recent projects in eight states. Costs were evaluated for both on-site mitigation and wetland mitigation banks on the common basis of acres. A detailed discussion and comparison of costs is presented in Section 4 and Appendix C. 


\section{Wetlancí Banking Concepts and Terminology}

In order to successfully discuss construction and operation of a wetland mitigation bank, with a clear understanding by all participants, important terms used in the banking process must be defined and standardized. Confusion exists concerning the terminology used in describing wetland restoration, creation, and enhancement projects (Lewis 1990). The recent increase in literature on wetland mitigation banking has added to the uncertainty of wetland definitions and terms. Often, specific wetland terms are used in different contexts in various parts of the country and are interpreted differently by government officials and the general public. For example, wetland mitigation banking has been defined as (1) an a priori, (2) a concurrent (sometimes defined as compensatory), or (3) an in lieu fee type of mitigative measure. Although all three terms are used in the context of banking, each has distinctive meaning in relation to the timing of the mitigation. Sometimes mitigation banking is referred to as advanced mitigation, and the term banking is not used at all. A wetland ecologist may describe a restored wetland as a reclaimed wetland, meaning returned to a wetland status. However, a lay person uses the same term of reclaimed wetland to describe a filled or drained wetland, meaning reclaimed for a nonwetland land use. Because of such differences, it is important to standardize terminology before wetland banking definitions become formalized within regulatory and statutory contexts at the state and federal level. Standardizing terminology enhances communication between scientists, regulators, managers, and the general public and minimizes the possibility of misinterpretation of wetland mitigation concepts. This report attempts to develop a coherent set of definitions for the key terms involved in characterizing wetland mitigation and wetland mitigation banking (see Appendix A).

Various data sources were used to synthesize banking terminology currently in use around the country into a single, coherent set of definitions. Wetlands restoration, creation, and enhancement terminology defined by Lewis (1990), in Wetland Creation and Restoration - The Status of the Science, aided in developing comprehensive definitions. Other important sources of information included the Corps of Engineers Wetlands Delineation Manual (USACOE 1987), Federal Manual for Identifying and Delineating Jurisdictional Wetlands (FICWD 1989), Classification of Wetlands and Deepwater Habitats of the United States (Cowardin et al. 1979), Guidelines for Implementation of Wetland Habitat Mitigation Banking (Minnesota Department of Transportation 1987), and Guidelines for the Establishment of Wetland Mitigation Banks (California Department of Fish and Game 1991). Technical reports, textbooks, journal articles, and state and federal regulations and legislation that are referenced in Appendix A provided additional information.

The terminology used in wetland mitigation banking can be approached from both technical and regulatory perspectives. The following sections discuss key definitions needed to understand the wetland mitigation banking process as well as the technical aspects concerning the design, construction, operation, and monitoring of the different types of wetland mitigation banks. 


\subsection{Bank-Specific Definitions and Terms}

Although more than 60 banking-specific definitions are presented in Appendix A, the significance of several key terms to the wetland mitigation banking process and how regulatory agencies currently view these terms is discussed below. In this discussion, wetlands are defined, and a discussion of methods of mitigating wetland impacts follows; finally, how banking fits into the overall wetland mitigation process is described. In addition, other key terms pertaining to the wetland mitigation process are defined.

\subsubsection{Wetlands - Regulatory Definition vs. Project Definition}

The federal regulatory definition of wetlands is as follows: "Those areas that are inundated or saturated by surface or groundwater at a frequency and duration sufficient to support, and that under normal circumstances do support, a prevalence of vegetation typically adapted for life in saturated soil conditions. Wetlands generally include swamps, marshes, bogs, prairie potholes, vernal pools and playa lakes and similar areas" (40 CFR 230.3, 1980 and 33 CFR 328.3, 1982). This definition, developed by the U.S. Environmental Protection Agency (USEPA) and the USACOE, was used in the 1987 Corps of Engineers Wetlands Delineation Manual.

Pending the recommendations of a National Academy of Scierces study, the Clinton administration is using the definition from the 1987 Corps of Engineers Wetlands Delineation Manual. The definition found in the subsequent manual published in 1989 Federal Manual for Identifying and Delineating Jurisdictional Wetlands (FICWD 1989) is still employed by some agencies. The definition of wetlands in the 1989 manual, prepared as a cooperative effort by the USEPA, the USACOE, the U.S. Soil Conservation Service (USSCS), and the USFWS, superseded the wetland definitions developed by various agencies for earlier manuals. The 1989 regulatory definition was based on previous definitions used by the USEPA, the USACOE (40 CFR 230.3, 1980 and 33 CFR 328.3, 1982), the USSCS (National Food Security Act Manual 1988), and the USFWS (Classification of Wetlands and Deepwater Habitats of the United States, Cowardin et al. 1979). The USEPA, USACOE, and USSCS definitions emphasized hydrology, vegetation, and saturated soils and included those areas that were vegetated under normal circumstances. However, the USFWS definition emphasized transitional areas located between terrestrial and aquatic systems, which could encompass both vegetated and nonvegetated areas (FICWD 1989). While all the definitions cited in the 1989 manual are used as guidance in the wetland identification and delineation criteria, the definition in the 1987 USACOE manual remains the official definition until final revisions from the National Academy of Sciences are made and subsequently approved by the current administration.

For the purpose of this project, a wetland is defined as follows: "An area inundated or saturated by surface water or groundwater (hydrology being the dominant factor) at a frequency and duration sufficient to support, and that under normal circumstances does support, a prevalence of vegetation (hydrophytic) typically adapted for life in saturated soil (hydric) conditions. Wetlands generally include swamps, marshes, bogs, prairie potholes, fens, wet meadows, tundra, 
and similar areas. Wetlands are often transitional zones between open water and dry land" (Lewis 1990). This definition, based on the federal agency definitions identified in the 1989 federal manual and similar in its scope, encompasses the three major factors used in identifying and delineating wetlands (hydrology, hydric soils, and hydrophytic vegetation), emphasizes that hydrology is the dominant factor, and provides a list (not all-inclusive) of representative types of wetlands. This definition is narrow enough to incorporate the major concepts for determining wetlands, but broad enough to allow for a diversity of wetland types.

\subsubsection{Off-Site Wetland Mitigation Methods}

Wetland mitigation (and subsequent banking) can be accomplished by various means. Wetland impacts can be mitigated by creating new wetlands from persistent upland or shallow water areas, by reestablishing or restoring wetlands on a site that historically supported wetland vegetation, or by enhancing the ecological functions and values of an existing wetland site. While each method is an acceptable mitigation approach, restoration currently predominates because of such factors as favorable topographical relief, potential existing seed-bank source, and conducive hydric soils. Because restoration sites historically supported a wetland environment (within the past several hundred years), design and engineering problems are often minimized.

Environmentalists favor mitigating by restoring wetlands, because these wetlands represent acreage beyond what currently exists. Creation of new wetlands is often less acceptable to environmentalists because of a lower probability of ecological success. Enhancing acreage is considered an acceptable practice, but it is difficult to accurately quantify the level of enhancement, especially how an enhanced wetland offsets the areal extent of wetlands destroyed by development. Many environmentalists feel enhancement does not satisfy the goal of no overall net loss. The greatest controversy surrounds the use of preserved wetlands as a method of mitigating development on other wetland areas. Preservation of a fully functioning wetland does not readily correspond to the concept of a national policy of no overall net loss. However, preservation of actively degrading wetlands at their present value represents a restoration of future lost value. The preservation method works best in saving an existing wetland from imminent destruction, combined with enhancing the wetland or restoring or creating adjacent or surrounding wetlands.

\subsubsection{Wetland Mitigation Banking - Regulatory Definition vs. Project Definition}

The current federal regulatory definition of wetland mitigation banking, as developed by the USFWS, is "habitat protection or improvement actions taken expressly for the purpose of compensating for unavoidable, necessary losses from specific future development actions" (Anderson and Rockel 1990, Short 1988). Various state and local regulatory agencies involved in wetland mitigation banking projects have also developed or are in the process of developing their own definitions for mitigation banking. For example, the Minnesota Department of Transportation (MnDOT) defines banking as "an account representing accrued debits and credits, arrived at through the Wetland Habitat Mitigation Bank process" (Minnesota Department of Transportation 
1987). DuPage County, in lllinois, defines the banking option as "intended to provide for the creation and restoration of wetlands to compensate for wetlands lost to development. The value of wetlands created must at least keep pace with the value of those being lost (thus, no overall net loss)" (DuPage County Stormwater Management Corımittee 1992).

In this report, wetland mitigation banking is defined as "a program or approach that permits unavoidable wetland losses which cannot be adequately mitigated at the site of impact to be offset with credits earned previously through mitigation actions undertaken off-site. Mitigation actions for banking may include restoration, creation, and enhancement of wetlands and, in special circumstances, may include the preservation of wetlands and adjacent upland areas." (See Appendix A for elaboration of this definition). This process consists of establishing a memorandum of agreement (MOA) or a memorandum of understanding (MOU), physically developing a wetland bank, establishing an accounting and management process, and operating a maintenance and monitoring program, prior to the associated wetland loss.

\subsubsection{Spatial Extent and Delineation of Wetlands}

Various terms, including buffer zones, nonwetland areas, transition zone, uplands, wetland boundaries, and wetland limits, are used interchangeably, but often with subtle differences of meaning, when describing and discussing wetlands, their boundaries, and surrounding upland areas. Buffer zones are areas of land or deep water adjacent to a wetland that may physically protect the wetland. These zones may limit human access, buffer the wetland from pollutants, and enhance the biological diversity of the wetland with species requiring adjacent upland or deepwater habitat. Nonwetland areas include those upland or lowland areas that are not deep-water aquatic habitats, wetlands, or other special aquatic sites. A transition zone is an area that changes from a wetland to a nonwetland environment or from a wetland to a deepwater habitat, often acting as the buffer zone. Uplands are those areas within the transition or buffer zone that do not have the appropriate hydrologic regime to develop hydric soils or hydrophytic vegetation. Uplands occurring within the floodplain are often referred to as nonwetlands. A wetland boundary is a ground point that shifts from a wetland to a nonwetland or an aquatic habitat. Although the wetland boundary will be shown on a map as a line, in reality the boundary is an ecological gradient where it is difficult to ascertain the precise delineation between wetland and nonwetland area. Wetland limits define the extent of the wetland by defining deepwater and upland limits using hydrologic, vegetation, and soil criteria. Wetland limit is a regulatory concept which is often legally defined within each state.

\subsubsection{Wetland Development and Management}

Bank developers/owners form the legal entity empowered to acquire property and create or restore and maintain wetland habitat upon that land. To date, these owners have mostly been state transportation departments, although some owners have been private corporations and individuals. The bank managers/operators are public agency officials (e.g., local, county, state, and federal) or 
private organizations (e.g., corporations, commercial developers, industries) representing the interests and goals of the wetland mitigation bank. The bank regulators are those federal or state agencies that control permitting, bank establishment, and bank usage.

\subsubsection{Wetland Processes - Function vs. Value}

The terms wetland function and wetland value are often used in conjunction with each other, and consequently there is a lack of clarity in definition of the two terms. From an ecological (e.g., physical, biological, or chemical process) point of view, floodwater conveyance, erosion control, water- $\varsigma_{\mathrm{S}}$ ality enhancement, or wildlife habitat are examples of wetland functions. Wetland values are an interpretation of the relative economic worth of wetland functions and can be either positive or negative.

\subsubsection{Wetland Bank Account - Currency}

Wetland currencies can be classified as acreage-based or value-based. The most widespread currency system is acreage-based, in which the number of debits (impacts) and credits (offsets) are based on acreage. Debit-to-credit ratios have been used in these programs to account for environmental risk. Typically, when impacts are planned to high-value areas or when using a mitigation method that has a greater risk of failure, higher credit-to-debit ratios are required. In some cases regulators have required higher credit-to-debit ratios for out-of-kind mitigation (such as creation). There are two rationales for the use of an acreage-based system. First, this system is administratively simple, requiring little accounting or measurement sophistication. Second, the ratio mechanism serves as a measurement of environmental risk and potential assurance against loss of net wetland values.

A value-based currency system combined with environmental performance bonds serves the goal of no overall net loss and reduces the risk of potential wetland-value loss. In a valuebased currency, the estimated value of impacted and bank wetlands is determined by a variety of procedures, including the USFWS Habitat Evaluation Procedure (HEP), the Wetland Evaluation Technique (WET), and other methods. The central difficulties with this type of currency are its measurement complexity and its greater monitoring requirements. With a value-based currency, the need for credit-to-debit ratios is eliminated. Further discussion of credit creation and currency is found in Section 3.2.2.

\subsubsection{Wetland Bank Account - Debits and Credits}

The exchange medium for debits and credits may be a habitat unit value, acreage measurement or any other agreed-upon measure of value with a defined and measurable unit. A wetland bank account debit is a unit of value used to measure an unavoidable wetland impact. 
Incurring bank debits is subject to approval by the wetland bank manager and the developer. A wetland bank credit is a positive unit measure of value gained by the creation, restoration, or enhancement of wetlands. A credit is created when a mitigation site is accepted into a wetland mitigation bank by the designated bank managers and regulators. The unused portion of unit value is the credit balance available to be offset by future wetland impacts.

\subsubsection{Off-Site Mitigation Type - A Priori, Concurrent Credit Use, and In Lleu Fee Arrangements}

A variety of developer/operator/user arrangements are possible in off-site mitigation. Three major impact/credit-use arrangements, in which the timing of impact to credit use for compensating wetland impacts varies, have often been used:

1. A priori banking,

2. Concurrent credit use, and

3. In lieu fee programs.

In a priori mitigation banking, an owner/developer creates a bank and achieves regulatorydetermined effectiveness criteria before the credits of the bank are used. Under this arrangement, an owner will have uncompensated expenditures for several years until credits are available for sale. Such uncompensated expenditures may make the use of this type of mitigation banking difficult for small entrepreneurs. Under a priori banking, the goal of no overall net loss of wetlands may be met. The temporal loss in a priori banking is depicted in Figure 2.1.

Two credit plans have been used with a priori banking. In the first type of plan, compensation in advance of the impacts establishes all credit allocations within the MOA or related agreements before the bank begins development. The credits are not expended until accrued in the bank. Once the bank begins operation, credits are withdrawn on a predetermined timetable. The second form of credit use is typical of other kinds of products. After the product has been made (i.e., credits created), credits are available for sale at any time and in any quantity (constrained by the number of available credits).

Concurrent credit use has been associated with department of transportation (DOT) developments. Under this arrangement, credits are expended as the bank is developed. This arrangement is analogous to a short-term loan at a financial bank, where the developer compensates impacts soon after the impacts occur by paying the debit to the bank (once the bank is in operation). Problems associated with this type of credit use are the temporal loss of wetland values and the possibility that debits may not be compensated if the bank fails to operate. The temporal loss associated with concurrent mitigation is depicted in Figure 2.2. The goal of no net loss may be met eventually with concurrent mitigation if mitigation ratios of greater than 1:1 are used. 


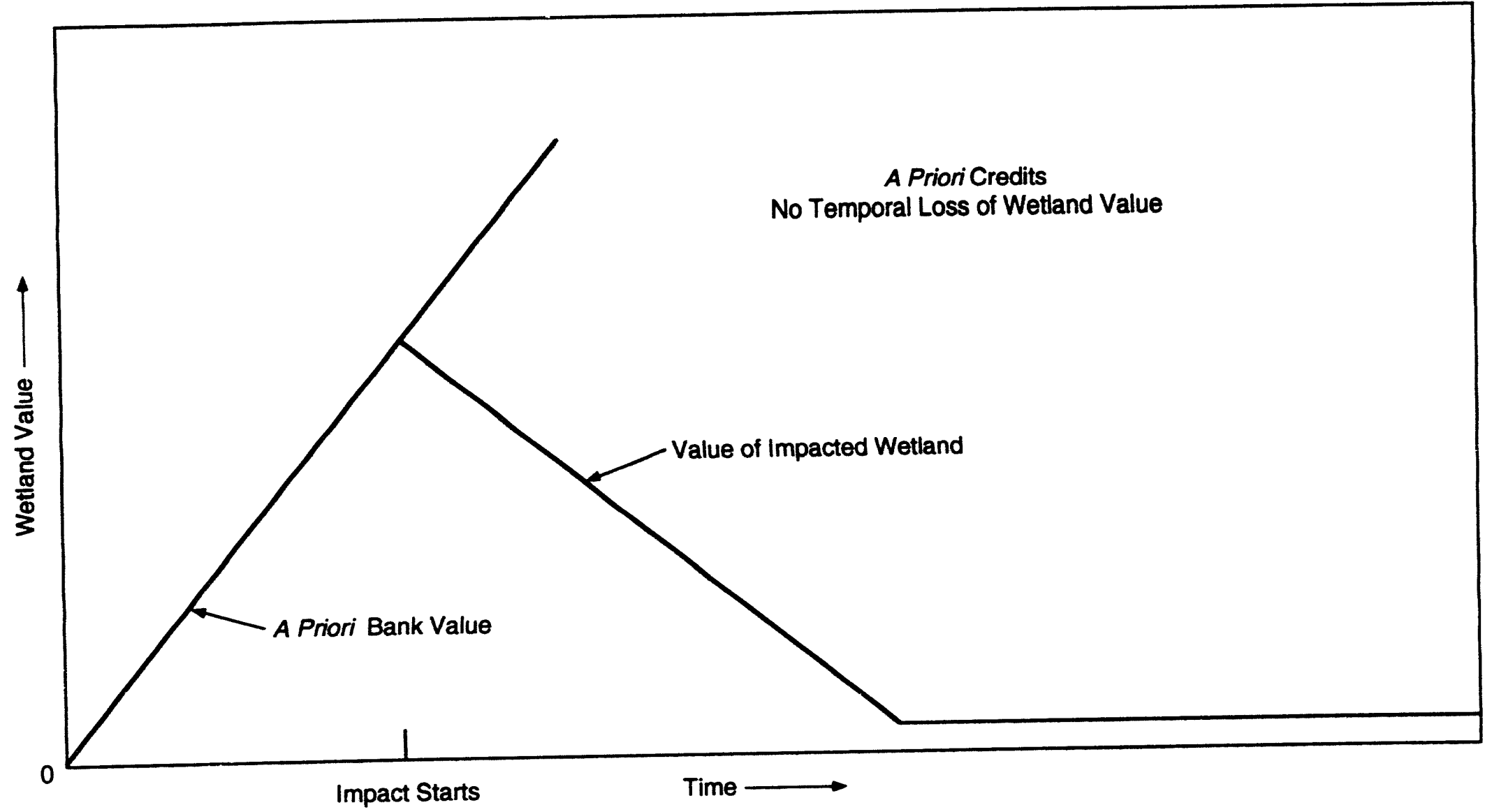

FIGURE 2.1 Temporal Loss of Wetland Values: A Priori Mitigation Banking (bank development occurs before impacts at time $=0$ ) 


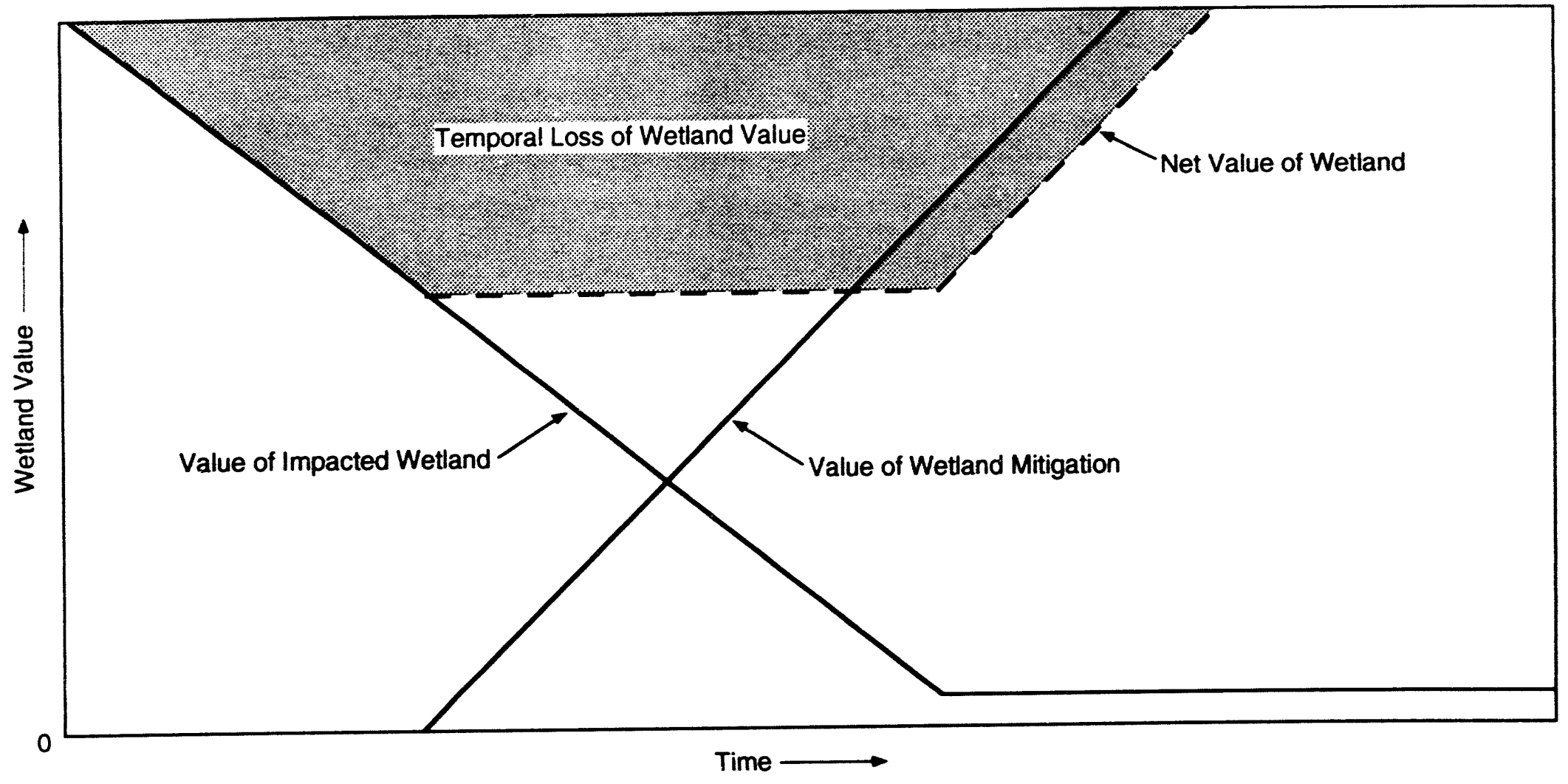

FIGURE 2.2 Temporal Loss of Wetland Values: Concurrent Mitigation Project (mitigation project begins as impacts occur; time $=0$ is the start of impact) 
In lieu fee credit programs typically entail debits being generated long before impacts are compensated. Under this program, firms impacting wetlands pay into a "sinking" or trust fund. Once the fund reaches a regulatory-determined level, a site is developed to produce credits to offset the uncompensated impacts. Environmental performance bonds may also be used as a tool to compensate for wetland impacts. After compensation occurs, the bond is released to the owning firm. Performance bonds are discussed in more detail in Section 3.2.2.

In lieu fee programs can present several issues. First, impacts will not be compensated until the fund is large enough to create a project to offset the impacts. Second, the connection between the impacting parties and those parties responsible for creating the offsetting bank is not firm. The accumulation of funds for an in lieu fee program does not guarantee that the revenues will be used for the creation of a wetland mitigation project (Shabman et al. 1993). The temporal loss associated with in lieu fee programs is depicted in Figure 2.3. The goal of no net loss may be achieved eventually if mitigation ratios greater than 1:1 are used for in lieu fee programs. Mitigation ratios for in lieu fee programs need to increase with the elapsed time from impact to compensation development to achieve no net loss.

A priori banking establishes the wetland value prior to wetland impact, thus ensuring no overall net loss. Only a priori mitigation banking projects are considered in this report.

\subsubsection{Wetland Banking Risk Categories}

Three major risk categories are identified with wetland mitigation banking: (1) economic, (2) ecological, and (3) regulatory. Economic risk is present in the variation of revenues and costs associated with any business project. Variance in costs or revenues will influence the profitability, and hence the cost-effectiveness, of private-sector mitigation banking. Environmental risk arises through variation of wetland mitigation bank values. As indicated previously, wetlands provide flood control, water purification, and many commercial products. The ecological effectiveness of mitigation banking is highly dependent on the natural characteristics of an area to be developed and the site design.

Net loss of value through mitigation banking is a primary concern for policymakers and bank owners/developers. Perceived environmental risk is often indicated by mitigation ratios. Regulatory risk occurs because of delays in bank approval, undue restrictions of credit use, and maintenance requirements above those set forth in the MOA. If loss of environmental/ecological value results, the bank owner will most likely be penalized through one of the regulatory requirements. Suspicion of the bank concept by regulators can result in delayed approval for the bank. 


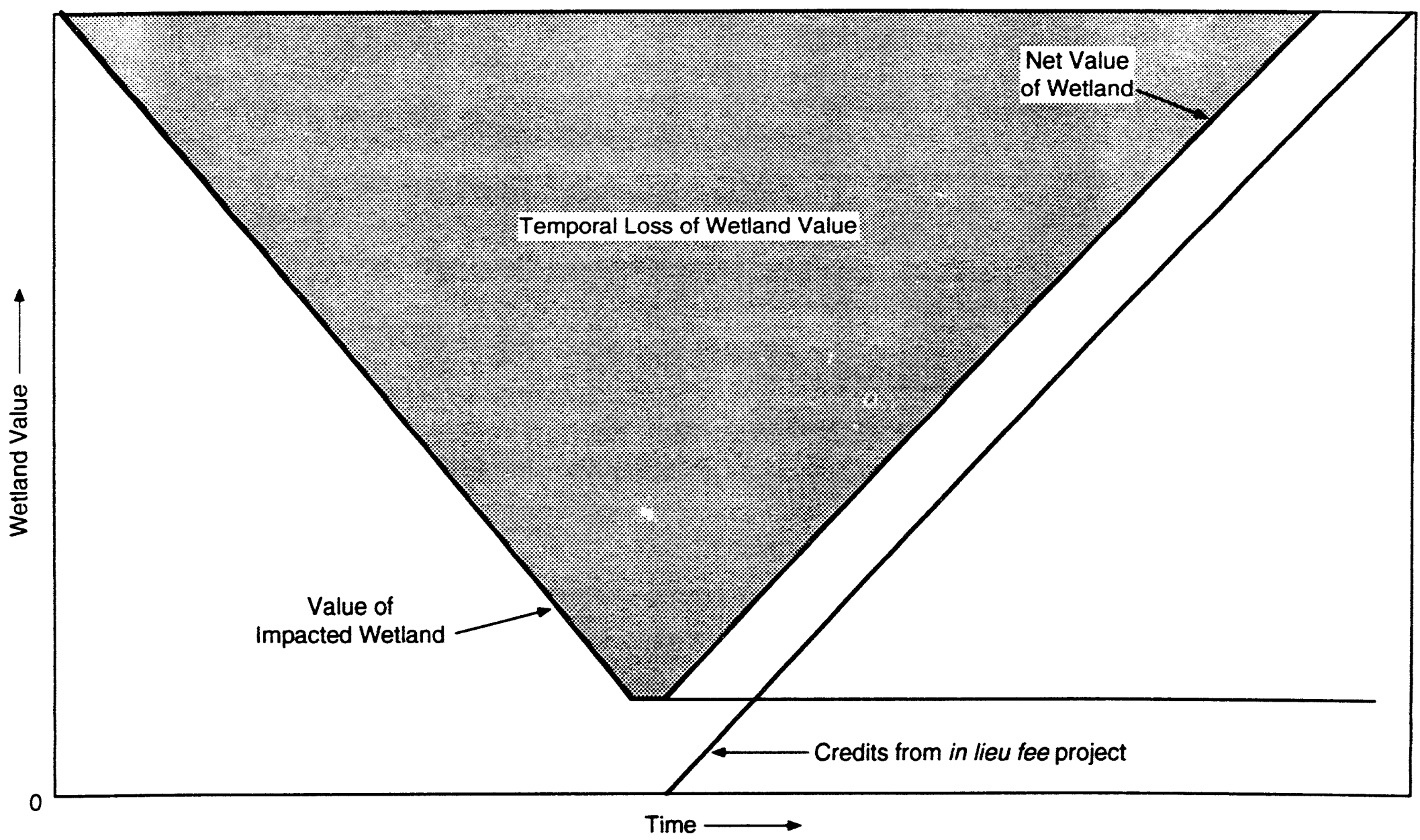

FIGURE 2.3 Temporal Loss of Wetland Values: In Lieu Fee Project (time $=0$ is the start of impact) 


\subsection{General Wetland Definitions and Terms}

A number of terms used in the preservation and development of wetlands must be defined to understand the concept of wetland mitigation banking. These definitions concern wetland systems, types of wetlands and associated habitat, ecological indicators, and design/engineering conccpts. There are five major aquatic/wetland systems: estuarine, marine, lacustrine, palustrine, and riverine. Wetland ecosystems are characterized as either coastal or inland and either fresh water or saltwater. The ecosystems consist of a variety of wetland types, including tidal areas, marshes, scrub-shrub areas, bogs (acidic and calcareous), wet prairie/wet meadows, prairie potholes, fens, bottomland hardwoods, swamps, tundra, pocosins, vernal pools, sloughs, and playas. Such ecological indicators as areal cover, vegetation density, dominance or frequency, and floral and faunal productivity are often useful for evaluating the functions and values of wetland sites. Knowledge of such design/engineering concepts as channelization, erosion, wind, wave barriers, flood conveyance, and storage capacity is also necessary to comprehend all aspects of the wetland mitigation banking process. Over 100 general wetland terms are defined in Appendix A. Although this appendix does not supply an exhaustive list of associated wetland terminology, it provides a good reference point for wetland terminology associated with the development of wetland mitigation banking.

\subsection{Wetland Mitigation Banking Types}

The scope of wetland mitigation banking includes several different institutional and agent relationships. Mitigation bank types are generally categorized on the basis of ownership, users, managers, and regulators. The same entity may fill all four positions, or there may be a different agency, institution, or individual in each capacity. There are a factorial number of bank-type categories possible, as listed in Table 2.1. This report will only deal with those combinations for which examples currently exist: (1) public agency owner/public user, (2) single private owner/single private user, and (3) single private owner/multiple private and public users. The central differences between bank types are purely project-related and should not affect the ecological or economic effectiveness (cost savings relative to project-specific mitigation activities) of the bank.

\subsubsection{Public Agency Owner/Public User Bank}

Public agency owner/public user mitigation banking is the most common type of banking, with transportation agencies as the primary developers and users. The public agency banks tend to be restricted to one specific agency acting as developer/owner. Currently, most of these banks are owned and operated by state departments of transportation (DOT). Funding comes from internal agency funds, except when the development project is able to charge user fees. In the future, the Federal Highway Administration may be allowed to aid in the funding of mitigation banks 
TABLE 2.1 Manager/Owner and User Relationships of Existing Mitigation Bank Sites

\begin{tabular}{|c|c|c|c|}
\hline & \multirow[b]{2}{*}{ User } & \multicolumn{2}{|c|}{ Manager/Owner } \\
\hline & & Public & Private \\
\hline Public & & 34 & Unlikely \\
\hline Private & & Unlikely & 4 \\
\hline Multiple & Private/Public & 2 & 3 \\
\hline
\end{tabular}

for highway development purposes. State resource agencies often take responsibility for establishment of ecological goals and long-term management and maintenance after credit drawdown.

Several state DOTs have come into conflict with state resource agencies regarding the status of the DOT banks. Some DOT wetland mitigation banks are essentially borrow pits hydrated to create credits to offset a DOT development project. The cost of creating additional credits is low in most cases, but this type of bank tends to have an extremely short life. Usually the number of credits are low and the debits follow shortly after the bank is created. Borrow pits are not considered high-value wetlands; their value is defined by their role within the watershed.

DOTs appear to avoid many of the regulatory hurdles faced by private developers, including permitting and agreement delays, monitoring requirements, and restrictions on the use of bank credits. Supporting this view is the large number of DOT banks relative to the number of private banks developed. State transportation departments and state resource agencies occasionally disagree as to what a mitigation bank entails, but these disagreements do not appear to cause extensive project delay or rejection, probably because DOT projects are always vested with the public interest.

Another type of public agency owner/public user bank has multiple users. These banks are primarily owned by such local public governments as cities, counties, and water management districts (e.g., City of Virginia Beach). This type of bank results, for the most part, from the local private sector facing increased property development and mitigation costs. Rapid development has caused pressure from the private sector on local government to enact ordinances or sponsor local interests at state and federal levels to develop mitigation banking. 


\subsubsection{Single Private Owner/Single Private User Bank}

The single private owner/single private user category of bank involves one permit used to mitigate long-term development projects. The banking development requires preapproval of all permitting agencies. This type of bank is used for large-scale developments, because it requires large financial resources to take advantage of the associated higher up-front costs. In most cases, the initial investment precludes the long-term single permit from being initiated by a small developer. A high future value can be achieved if the resources are available at the start of the project. Prior to beginning actual work, the project development and potential impacts are indicated in a resource plan, as are the number of credits used per project and the wetland area from which these credits will be drawn. Land purchase and wetland development occur before project development.

A priori mitigation banking establishes bank credits before development begins. A waiting period may be specified before credits can be drawn, and in some cases, additional credits may be available, depending on effectiveness criteria being met and/or time passing. This method has been used in most of the single owner/user mitigation banks examined and, in particular, for the Fina LaTerre bank in Louisiana and the San Joaquin bank in California.

\subsubsection{Single Private Owner/Multiple Private and Public User Bank}

Whereas some mitigation banks are established for the purpose of cost minimization for private and public projects, profit maximization can be considered a typical goal for entrepreneurial banks. This latter type of bank may also be established as a utility-maximizing venture, as in the case of the Chimento Bank in New Jersey. While we can assume that profits are utility-enhancing for the owners, potentially a primary reason for the establishment of such a bank could be to stop or restrict housing developments near other tracts of housing. However, this type of goal may be the exception to the general rule of profit maximization.

The Springtown Natural Communities Reserve, developed by $E^{M A X}$, is an example of a single private owner bank. Although this site was not visited by ANL, discussions were held with

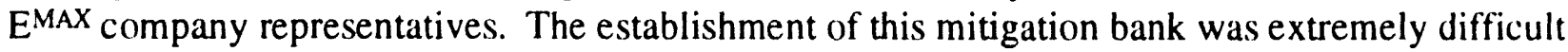
due to both financial constraints for land acquisition and development and regulatory barriers that required a significant level of financial resources. EMAX was supported in its efforts to establish a mitigation bank by the home builder, Kaufmann and Broad. The bank can be considered a hybrid of a priori banking and concurrent mitigation. Springtown holds the land for the mitigation bank but does not begin mitigation until credits are purchased. The local department of fish and game authorizes any purchases of the bank credits and specifies the exchange ratios and timing of the mitigation relative to impacts. The mitigation banking developer is free to set prices. With the funds received, Springtown constructs the type and amount of wetland required. The department of fish and game will specify the option for concurrent development or a priori compensation. Under this banking arrangement, the developer pays the bank owner after approval by the resource agency. 


\section{Evaluation of Major Wetland Banking Factors}

In this section, the major ecological, economic, and management/regulatory factors affecting wetland mitigation banking are evaluated. Each factor is discussed by examining the physical characteristics, issues and concerns, and risks associated with those banks visited by ANL staff. Ecological information to establish the physical and biological parameters surrounding wetland mitigation is provided in Section 3.1. Biscussion of the economics of mitigation in Section 3.2 provides a clear rationale for wetland banking. Finally, the management/regulatory information in Section 3.3 helps to determine the feasibility of the banking concept. Wetland mitigation banks visited during the course of this study are shown in Table 3.1. Detailed information for each of these banks is provided in Appendix B.

\subsection{Ecological Factors}

The major ecological characteristics of the wetland banks visited by ANL staff are described in the following sections. Issues of concern include the priority of location over biological parameters in siting banks, the preexistence of threatened and endangered species, and the use of the habitat evaluation method (e.g., HEP and WET) for establishing credits vs. acreage currency. The risk factors involved in the potential loss of wetland function and value on temporal and spatial scales are addressed. Finally, information is provided concerning the use of the banking option to avoid ecological risks.

TABLE 3.1 Wetland Mitigation Banks Visited by ANL Staff

\begin{tabular}{|c|c|}
\hline Bank & Location \\
\hline $\begin{array}{l}\text { Bowers Hill Wetland Mitigation Bank } \\
\text { Bracut Mitigation Bank } \\
\text { Chimento Wetland Mitigation Bank } \\
\text { Chula Vista Bayfront Marsh Habitat Credit Reserve } \\
\text { Creeds Wetland Mitigation Bank } \\
\text { Fina LaTerre, Inc., Wetland Mitigation Bank } \\
\text { Minnesota Wetland Mitigation Banking System } \\
\text { Prairie Pothole } \\
\text { Staples Mitigation Bank } \\
\text { Wawina Lake Restoration } \\
\text { North Lakes Park Wetland Mitigation Bank } \\
\text { Otterdam Swamp Wetland Mitigation Bank } \\
\text { San Joaquin Marsh } \\
\text { Winfield Creek Wetland Mitigation Bank }\end{array}$ & $\begin{array}{l}\text { Bowers Hill, Virginia } \\
\text { Arcada, California } \\
\text { Monmouth County, New Jersey } \\
\text { Chula Vista, California } \\
\text { Virginia Beach, Virginia } \\
\text { Theriot, Louisiana } \\
\text { Hoffman, Minnesota } \\
\text { Staples, Todd County, Minnesota } \\
\text { Itasca County, Minnesota } \\
\text { Tampa, Florida } \\
\text { Greensville County, Virginia } \\
\text { Irvine, California } \\
\text { Wheaton, Illinois }\end{array}$ \\
\hline
\end{tabular}




\subsubsection{Characteristics}

\subsubsection{Vegetation}

During the study, different ecological types of wetlands were visited, including freshwater marshes, coastal saltwater marshes, forested wetlands, scrub-shrub wetlands, and prairie potholes. Wetland plants (naturally occurring or planted) included floating forms (e.g., duckweed, waterfern); emergents (e.g., waterlilies, cattails); transitional grasses and sedges (e.g., cordgrass, three-way sedge); and shrubs and trees (e.g., buttonbush, bald cypress). Common freshwater and saltwater plant species found along the Eastern Coastal Plain banks (e.g., Chimento, Creeds, and Bowers Hill banking sites) and the Gulf Coastal area (e.g., Fina LaTerre banking site) include such plants as smooth cordgrass (Spartina alterniflora), salt-meadow cordgrass (Spartina patens), saltgrass (Distichlis spicata), glasswort (Salicornia sp.), and black or needle rush (Juncus roemerianus). In addition, southern forested wetland banks contain stands of bald or swamp cypress (Taxodium distichum), often intermixed with saw or cut grass (Cladium jamaicense) or black or needle rush (e.g., North Lakes Park banking site in Florida). Along the Southwestern Coastal area (e.g., Chula Vista Bayfront Marsh banking site), common species include California saltgrass (Spartina foliosa), glasswort (Salicornia pacifica), seepweed (Suaeda californica), and batis or saltwort (Batis maritima). There is a great diversity in the common plants found in freshwater marshes in the interior portions of the country (e.g., Winfield Creek and Minnesota DOT banking sites); many contain reed grass (Phragmites communis), cattail (Typha spp.), wild rice (Zizanis aquatica), maiden cane (Panicium hemitomon), saw or cut grass (Cladium jamaicense), sedges (Carex spp.), bullrush (Scirpus spp.), and spike rush (Eleocharis spp.), as well as pickerelweed (Pontederia cordata) and arrowhead (Sagittaria spp.) (Mitsch and Gosselink 1986). Additional wetland plants that were found in the specific banking sites visited are listed in Appendix B.

\subsubsection{Wildlife}

Wetlands support a wide variety of species of fish, shellfish, birds, amphibians, reptiles. and mammals. Small forage fishes (e.g., minnows) dominate freshwater wetlands, while larger fishes (e.g., gar, bullheads, bluegills) use wetlands diurnally or seasonally for breeding and spawning (Hammer 1992). Amphibians (e.g., frogs, toads, and salamanders) and reptiles (e.g., snakes, turtles, and alligators) use both aquatic and terrestrial habitats for sources of food and shelter and often require that a portion of their life cycle be in or adjacent to a wetland environment. The diversity of bird species in wetland areas is well-documented. Numerous species either frequent and/or nest in and adjacent to wetland areas: ducks, geese, swans, herons, egrets, ibis, loons, pelicans, cranes, and various species of songbirds, as well as birds of prey such as eagles, falcons, and owls. Various species of mammals inhabit wetlands, either perennially or at certain times of the year. Wetland-dependent mammals include such species as muskrat (Ondatra zibethica), nutria (Myocaster coypus), beaver (Castor canadensis), marsh rice rat (Oryzomys palustris), water shrew (Sorex palustris), and swamp rabbit (Sylvilagus aquaticus) (Hammer 1992). In addition, many terrestrial species (e.g., raccoons, coyotes, and deer) use wetlands for 
food and shelter at various times during the year. Wildlife species specific to the various wetland banking sites visited during the study are listed in Appendix B.

\subsubsection{Threatened and Endangered Species}

Often, federal- or state-listed threatened and endangered species either occur or potentially can occur in a wetland environment. Of the species on the threatened and endangered list, $15 \%$ of the mammals, $31 \%$ of the birds, $31 \%$ of the reptiles, and $54 \%$ of the fish are either entirely dependent on wetlands or are found within wetland habitat for a portion of their life cycle (Hammer 1992). Although there is potential for many of the visited banking sites to harbor a federal- or state-listed threatened or endangered plant or animal species, only one site, Bracut Marsh, knowingly has a state endangered species, the Point Reyes bird's beak (Cordylanthus maritimus ssp. palustris) located within the boundaries of the site. Although not currently found on-site, the Humboldt Bay owlclover (Orthocarpus castillejoides var. humboldtiensis) could also be supported. At the Chula Vista Bayfront Marsh banking site in San Diego, California, bank managers are attempting to entice the least tern (Sterna albifrons), a state endangered species, to live and nest at the site. There is currently a habitat protection program and also active nesting sites of least terns at the nearby Chula Vista Wildlife Preserve.

Although not considered a rare, threatened, or endangered species, the wood duck (Aix sponsa), which was almost extirpated around the turn of the century, is still a desired species in many parts of the country. In Minnesota, the state DOT in conjunction with the state Department of Natural Resources (DNR), established nesting boxes to attract wood ducks to the Rice Lake/Staples banking site. While wood ducks reside in the area, none have used the constructed nesting boxes to date. Similarly, another endangered species, the American alligator (Alligator mississipiensis), is prevalent at the Fina LaTerre banking site. Because they have increased by substantial numbers, several alligator nesting sites are located and tagged at the 5,(0)()-acre site, and some of their eggs are removed each year by alligator farmers.

\subsubsection{Solls}

Soil conditions at the banking sites that were visited varied from previously existing hydric soils, to soils becoming hydric in nature through man-made operations, to nonhydric soil conditions. For example, the soils at the Chimento banking site in New Jersey consisted of mixed fill of unknown origin. However, the soils at the lower elevations of the Chimento site, except for the mounded soils, are being inundated and probably will soon become hydric, even without additional human alteration of the local hydrology. At the Otterdam Swamp banking site in Virginia, organic soils were imported to the site to establish wetland vegetation in conjunction with altering of the local hydrology. This procedure appears effective in the lower elevation areas of the site, but at higher elevations, large areas consisting of only B-horizon material are devoid of vegetation. These areas need to be established and to retain organic soils for revegetation of wetland plants. At the Bracut banking site in California, buried wood debris from previous milling 
operations exists below the poorly drained, silty-clay loam soils. While this buried debris might not adversely impact the existing soil conditions at the surface, it does limit any future mitigative practices involving regrading or altering site hydrology. If portions of the site were recontoured or the hydrology substantially modified (i.e., removal of the surrounding dikes), significant erosion of the soil layer covering the wood debris could occur and result in wood debris getting into the bay area, with potential adverse results to the bay environment.

\subsubsection{Hydrology}

While soil improvement is important to the establishment of wetland plants, hydric soil conditions are dependent upon the existing or engineered hydrology. Therefore, the primary critical factor determining the ecological effectiveness of a wetland bank is proper design and control of the hydrology. At banking sites without properly engineered hydrology, the necessary hydric soils were not retained, a sufficient number or diversity of wetland plants were not attained, and a spatial succession of wetland to nonwetland species of plants and animals was not observed. For example, at the Northside Park banking site in Florida, even though a weir was installed to back water into the forested (cypress swamp) wetland area, there was no indication that any substantial amount of standing water occurred in the past 20 years. Unless other modifications are made to ensure periodic inundation, the site will cease functioning as a forested wetland area. At the Bracut banking site in California, there was not enough water from the bay area to adequately hydrate the marsh on a consistent basis. Additional steps are currently being taken to cut a second breech in the earthen dike surrounding the marsh to allow more water from the bay to enter, with the hope of enhancing the wetland site. At the San Joaquin Marsh banking site in Orange County, California, it was apparent (due to the climate and geohydrology) that without adequate water being pumped into the wetland system, the wetland would eventually fail. Whether a site is located in a dry, desert/Mediterranean climate, such as southern California, or a subtropical, wet region, such as Florida, unless water is controlled by correctly engineered hydrology, significant problems may occur, resulting in the eventual demise of the wetland.

\subsubsection{Issues and Concerns}

Because many sites visited were relatively new or still in the planning stage, it is difficult to assess the effectiveness of maintenance and monitoring programs for the banking sites. In discussions with persons involved in the development of the banking sites visited, it was determined that the prevailing objective was to establish the bank, monitor it for several years, and then perform only an occasional, qualitative review of the site on an ad hoc basis. Sites located in the wetter, eastern, and southern regions (temperate and subtropical climates) of the country will probably require less maintenance than arid western sites (Mediterranean and desert climates), where water is being mechanically pumped to and distributed on the banking site. Such sites require high maintenance to ensure that the pumps and water-distribution systems are operating properly. In addition, the coastal sites where saltwater intrusion is a problem will require intensive monitoring programs to ensure that adequate freshwater is available to limit saltwater levels. 
The siting of a wetland mitigation bank depends more on land availability, economic factors (cost of land), and agency interest or mission than on ecological merit or need. State DOTs were interested in locating banking sites in the highway district near proposed roadway projects that could be used as a good source of fill. Once this criterion was met, consideration was given to locating sites adjacent to existing natural areas. For example, state DOT freshwater-marsh banking sites in Virginia and prairie pothole banking sites in Minnesota were all located adjacent to existing roadways because of fill material and land availability. Other siting characteristics include using existing public lands rather than private land (e.g., the Winfield Creek site in Illinois) to eliminate land-acquisition costs and siting banks within regulatory districts (e.g., MnDOT highway districts) for ease of administration.

The ecological siting criteria used for the various banks was generally biased toward land availability and proximity to the proposed project, rather than toward ecological factors. Banks are often sited on the same type of wetland that will be impacted in the future. There appeared to be little thought to developing the bank in the context of the larger, regional ecosystem. The driving force, especially from the standpoint of state DOTs, was to mitigate a specific project with enough excess credits to allow for impacts on future projects within a given highway district.

A major ecological issue concerns the use of a credit system (currency) based on acreage versus a system based on the value established by a habitat evaluation method. Acreage systems are simple to monitor and regulators can easily understand what is being traded. However, systems based on acreage and acreage ratios lack the ecological sophistication to accurately realize the ecological value of those wetlands that are being destroyed or credited. The use of acreage implies the same quality for each wetland destroyed or traded. The HEP and the WET allow better understanding of the ecological functions and values of a wetland area, but in reality, the use of a habitat evaluation procedure is not perfect, because subjective values are incorporated. Although partly qualitative in nature, such procedures allow a like comparison of wetlands being credited or destroyed, where values and functions rather than acreage are traded.

Careful consideration must be given to the location of the created or restored wetland site. Wetland restoration and creation might result in the development of new critical habitat conducive to threatened and endangered species. However, proper planning must be implemented to ensure that the pre-bank habitat does not harbor any threatened or endangered plant species. For example, the Bracut, California, banking site currently harbors a state endangered plant species, Point Reyes bird's beak (Cordylanthus maritimus ssp. palustris). A second plant species, Humboldt Bay owlclover (Orthocarpus castillejoides var. humboldtiensis) might also exist at the site. Any future enhancement activities (e.g., raising the water level) must be considered in the context of how hydrologic change could impact the status of the existing threatened and endangered species and the potential viability of others.

Another ecological issue concerns the function and value of wetlands over time. Ecosystems are dynamic systems from both spatial and temporal points of view. Therefore, credits (value) given for various wetland functions at any point in time for any given location can change. For example, at the MnDOT Staples Marsh (Rice Lake Restoration) wetland banking site in Minnesota, the water level was raised to create wetland habitat. A number of trees were 
drowned, resulting in an excellent nesting habitat for various bird species, including the great blue heron (Ardea herodias), green heron (Butorides virescens), and black-crowned night heron (Nycticorax nycticorax). However, depending on the species inundated and its ability to withstand decay and rot, the tree may remain upright from a few years to several decades or longer. Therefore, the ecological value might be high from a standpoint of nesting sites, but it may decrease in areal extent over time.

Most mitigation banks are much less than 10 years old, and an assessment of ecological effectiveness would be premature. Successional changes in vegetation are evident at those banks operating for approximately 10 years or longer, but the ecological effectiveness of the older operating banks appears to be mixed. Many wetland plant species have been established at the Bowers Hill banking site in Virginia because the area was excavated (for a borrow pit). However, the Bracut site in California has substantial well-documented problems. Certain engineering practices, such as removing the dike along the marsh, could allow enough water into the site to enhance wetland vegetation, but at the same time, the decomposing wood debris buried under the site would become exposed and possibly get into the bay, resulting in water-quality problems in the bay area. The Otterdam Swamp banking site in Virginia still has areas without organic soils that are devoid of vegetation. These areas need to be restored for a totally functioning wetland bank. However, at the Fina LaTerre bank, the ecological effectiveness has been documented by the HEP evaluations performed by USFWS. Thus, each bank will have unique criteria for determining its ultimate ecological effectiveness.

Although ecological considerations are not always the driving force behind the location of banking sites, they are always taken into consideration. If possible, banking sites are often incorporated into existi.ng natural or semi-natural areas. For example, the three Winfield Creek banking sites are located within two park areas and a natural area that are part of a green-belt plan for DuPage County, Illinois.

\subsubsection{Risk Factors}

Ecological risk relates to the potential variability in bank value due to environmental considerations. Factors such as weather, site conditions, design, and local hydrology will influence ecological risk. A loss of wetland values caused by this variability will, in turn, impact the potential effectiveness of the mitigation bank. Failure to establish wetland values or the loss of wetland values over time will probably necessitate additional expenditures by the bank owner, endangering the effectiveness of the bank. The additional expenditures may come in the form of added biological establishment and improvement costs, increased monitoring, or increased retirement expenditures. Ecological risk is intimately tied to economic costs, which are discussed in Section 3.2.

From a federal-policy perspective of no overall net loss, the temporal loss of wetland values is undesirable. The temporal loss of wetland value in mitigation banking is defined as wetland values lost during the intervening time between wetland development impacts and the 
creation of compensatory credits within a mitigation bank (see Figures 2.1-2.3). Temporal loss in wetland value in an area resulting from the time sequence of development can be avoided with mitigation banking. For example, a project development that infringes into a wetland will reduce the ecological value of that wetland. Only after construction work has been completed on the project can mitigation activities occur. During the intervening time period, wetland values may be lost or reduced. An established wetland mitigation bank allows the ecological value to be in place prior to any construction activities at the proposed deveiopment site.

The spatial loss of wetland value must also be considered. For example, if a road development requires the filling of a wetland, the fill reduces the ability of the impacted wetland to hold stormwater. To offset the impact, a developer can acquire credits from a mitigation bank within the area. However, the credits do not represent additional value within the impacted area for stormwater holding. Some spatial value of local wetlands has been lost, but some value has been gained in the area represented by the bank credit.

While banking attempts to minimize both spatial and temporal loss of wetland value, the risks of value reduction (and potential improvement) still exist. The bank owner seeks to create, increase, and maintain wetland values, as value generates credits. In cases where wetland credits derived from an acreage measurement are the targeted commodity, the bank owner is required to establish certain ecological benchmark conditions for the bank and maintain them over time. Improved wetland values under an acreage system could result in lower ratios being required for debit to credit exchanges.

Ecological risks should not vary because of who the bank owner is or who is the buyer of the bank credits. However, regulators may favor those owners who can demonstrate the ability to develop successful mitigation and mitigation bank projects, have the funds available to correct difficulties as they occur, and can readily be compelled to correct possible losses in bank values.

As stated previously, fluctuations in wetland values will influence expenditures required for site maintenance, improvements, and terminal value. Fluctuation in value will also influence the number of credits available from the site, thus influencing the revenue potential of the bank. The downside of ecological risk for the wetland mitigation bank owner is increased expenditures on monitoring and maintenance, fewer credits for sale, possibly lower terminal value, and higher retirement funding; negative regulatory response for bank operation is also possible. The upside is increased credits, lower improvement costs, and, possibly, better regulatory relations.

Several possible strategies exist for mitigating the downside ecological risks associated with wetland mitigation banking. These include proper, advance planning and site examination; adequate monitoring to find potential problems; and choosing achievable effectiveness criteria for the site. To reduce or mitigate the economic impacts associated with ecological risk, environmental performance bonds and transfer of the bank to a third party at the time of bank retirement have been proposed. 


\subsection{Economic Factors}

In this section, various mitigation banks and the types of credit-usage schemes currently being used are described. Issues and concerns are discussed regarding construction, monitoring, credit creation and pricing, and economic barriers and incentives for mitigation banking. Finally, risks are defined in terms of construction, credit sale, and project-offset risks.

\subsubsection{Charactoriatics}

Several mitigation bank types and credit-usage schemes were encountered. For the most part, wetland mitigation banking has been an activity of such public agencies as DOTs. This mix is changing as there are a number of entrepreneurial banks now in the planning stages. Previously, mitigation has tended to occur concurrently or after the wetland has been impacted. Also, mitigation banks have tended to be located away from the impact site. Banks were established adjacent to an impacted site in only a few of the cases investigated.

Possibly the oldest mitigation bank is the Bracut Marsh developed and administered by the California Coastal Conservancy (CCC). The CCC approves development permits in coastal areas. while the California Department of Fish and Game manages the site and provides long-term maintenance. Bracut uses an acreage system for credit transfers. Most of the credit transfers were used for such public development projects as bridge expansion, highway maintenance, road expansion, and municipal construction. The ratio used for the public projects was 1:1. One commercial private developer was allowed purchase of credits at a ratio of 1.5:1.

From economic and policy perspectives, Bracut worked extremely well. The parties involved estimated that the credit purchases saved approximately half the time and effort required for typical permitting and mitigation activities. While the time and effort savings were for public development projects, Bracut may demonstrate that once a bank is established and credits are permitted to be withdrawn, delays and retrospective regulatory review may decrease. It was also estimated that mitigation banking saved approximately $10 \%$ of the construction and maintenance costs that would have been expended if individual mitigation projects were required.

The Bracut Mitigation Bank development costs are:

Land purchase

Planning cost

Construction cost

Phase I restoration cost

Phase Il proposed restoration

Estimated total cost
$\$ 130,000$

$\$ 33,000$

$\$ 98,000$

$\$ 26,000$

$\$ 67,000$

$\$ 354,000$ 
Bracut had several design failures that threatened, and continue to threaten, its viability as a mitigation site. The restoration costs indicated should be considered maintenance costs to ensure proper functioning of the mitigation bank. From a regulatory perspective, design failures are environmental risks: from a development perspective, design failures are serious economic risks.

An issue arising from the operation of the Bracut Mitigation Bank is in pricing credits. Whereas the market and development costs should set the price of a credit at a level that guarantees a return from the project, some public agencies have not developed methods to ensure a proper return on funds invested in the mitigation bank. Bracut recovered $\$ 196,(1)(1)$ through credit sales as compared with its development, maintenance, and operation costs of approximately $\$ 3.54,(1)(0)$.

While permitting time and the associated administration and delay costs were saved at the Bracut Mitigation Bank, many sources indicate that the establishment of a mitigation bank required significant resource expenditures. Multijurisdictional conflicts regarding permitting, development, goals, and credit usage inflated preproject costs. For example, the Minnesota mitigation banking experience illustrates that the initial administrative and regulatory costs may be two to three times the planning and construction costs. These costs should decrease once an MOA has been established and regulators gain more familiarity with banking.

The mitigation bank most applicable to the oil and natural gas industry is the Fina LaTerre Mitigation Bank, established by Tenneco and sold to Fina LaTerre, Inc. The Fina LaTerre bank uses hahitat units as a measure of credits for development. Several mitigation techniques are used. including enhancement, restoration, and preservation. The Fina LaTerre mitigation bank is privately owned and operated with oversight from a variety of state and federal agencies. Fina lallerre. Inc., markets the credits 10 outside buyers and also uses the credits for their own developments. Through the use of a value-based credit system, it is possible for Fina LaTerre to have an increase in the number of credits over time. The site is routinely monitored to assess value and prevent value losses. The system, which creates credits at Fina LaTerre, assumes that the site will disappear in 77 years without maintenance. Therefore, preservation prevents the natural loss in value. For this reason, the habitat value of the bank is periodically reviewed.

The estimated planning and construction costs of the Fina La'Terre bank were $\$ 50(0,0(0)$. Maintenance and monitoring are believed to require $\$ 1.0$ million-\$1.5 million over the bank's 25-year life span (with a possible extension of up to 75 years). Regulatory costs associated with the initial development were probably high, if the experience at other banks is an accurate sample of problems encountered in developing mitigation banks. Fina LaTerre, Inc., has stated that the bank has been successful in reducing both development time and regulatory delay, which has saved costs for the Fina Oil Co. projects involved.

One of the most organized and effective mitigation banking systems is that of the Minnesota DOT. The state is divided into DOT highway districts. The Minnesota DOT projects within a district are able to draw credits from any bank located in the same district. Credits are based on a modified habitat evaluation procedure developed by the Minnesota DOT. By using this systematic and value-oriented approach to mitigation and mitigation banking, significant cost savings can be 
realized, and regulatory burden; can be avoided. While avoidance and minimization of project impacts must still be tried, the high remitting cost can be avoided. In-kind, on-site mitigation has been avoided in favor of credit purchases that, in some cases, are off-site and out-of-kind, but which have the same ecological value and lower mitigation costs. Construction and development costs on a per-acre basis have ranged from approximately $\$ 10,000$ to $\$ 50,000$. The higher end represents costs associated with urban developments, land purchase costs, and excavation costs. The Minnesota DOT estimates associated monitoring, maintenance, and personnel costs, on average, are two to three times greater than bank development costs.

The Virginia DOT has also used mitigation banking for several years; it uses an acreage system and must follow all sequencing requirements as defined by the Council on Environmental Quality. The Virginia DOT had some difficulty with regulatory restrictions, but it has not found these restrictions to be overly burdensome. The use of mitigation banking for the Virginia DOT is projected to increase because of increasing wetland impacts and the high costs of on-site mitigation. For the Goose Creek Wetland Mitigation Bank, the design and conversion cost of a borrow pit site was approximately $\$ 7,000$ per acre. The Virginia DOT is able to maintain a relatively low-cost banking monitoring program because it uses the acreage accounting system and because of the centralized nature of the mitigation bank.

For the other mitigation banks visited (see Appendix B), the cost data from the planning stages were missing. However, these banks did illustrate several economic issues. For the most part, the regulatory approval process is easier for public developments and mitigation banks than for private banks. Even so, there may be serious regulatory problems present even for public development projects. As indicated by several of the public developers, considerable effort was needed to persuade state resource agencies to approve the mitigation bank concept. A survey was performed by ANL concerning state regulatory treatment of mitigation banking. Several DNR/DEP officials indicated that mitigation banking was not occurring within their states, while in fact, the DOTs and municipalities in those same states may have permitted mitigation banking for many years. The conflict between the two positions indicates that there is a serious lack of communication between regulatory agencies. The owners of such private mitigation banks as the Chimento Wetland Mitigation Bank, the Irvine Company Mitigation Bank, the Spring Valley Natural Reserve, and the Disney Development Corporation's Walker Ranch advanced mitigation project indicate that regulators have presented serious barriers of delays in the approval process and that costs are higher due to those delays. Periods of three years and more have been spent attempting to gain approval for some of these mitigation banks. High initial costs associated with regulatory barriers to mitigation banking may reduce the value of this land-management technique for private developers.

A subgroup of both private and public mitigation banks are the municipal mitigation bank developers, such as Virginia Beach, Hillsborough County, and DuPage County. While the development is essentially public, private developers are allowed to purchase credits. These banks have arisen in areas of high growth and greatly increased property values, making mitigation activities very expensive. Of the three mitigation banks listed, only Hillsborough is developed (and all its credits have been drawn down). Regulatory delays and the associated increased costs 
made mitigation banking difficult for Virginia Beach and Hillsborough County, but DuPage County has avoided these restrictions through a detailed wetland ordinance.

Credits of these public banks are largely established through an acreage-based system, except as previously indicated. Most public developers have requirements of 1:1 ratios, while private developers face requirements of $2: 1$ or greater.

\subsubsection{Issues and Concerns}

Wetland mitigation banking has been shown to be a cost-effective alternative to traditional project mitigation (Short 1988). In this section, several cost issues involved in mitigation banking will be examined. First, environmental performance bonds will be defined. Second, construction and monitoring cost savings will be presented. Third, credit pricing and measurement issues will be discussed. Finally, potential incentives and disincentives for the development of wetland mitigation banking will be explored.

\subsubsection{Environmental Porformance Bonds}

An environmental performance bond may be used by a regulator as a tool for securing a mitigation project or banking project. An entity seeking to develop an area that will result in a temporary loss of wetland value may be required to purchase credits from a local wetland mitigation bank or $t 0$ purchase a bond from a regulatory agency. After the development has taken place and any on-site mitigation requirements have been met, the value of the bond is returned or an agreed amount of the purchased credits sold. For a banking project, the bond could be used by the regulator as a tool for enforcing proper monitoring and maintenance of the bank. The payment could be required before the bank is constructed or it could be paid during operation through a premium on credit prices or at the bank's drawdown. Bank credits could be sold if the bank owner holds the bond and, thus, assumes responsibility for future monitoring and maintenance. The bond would be redeemable after certain ecological criteria are met. Performance bonds may be applied to a priori banking, concurrent mitigation, and in lieu fee programs.

\subsubsection{Construction and Monitoring}

One of the rationales for the establishment of wetland mitigation banking is the potential for cost savings compared with traditional mitigation activities. The cost savings come from economies of scale present in construction and operation and from reduced costs associated with permitting and delay. Although there is significant variance in mitigation banking and mitigation project costs, and the sample size is relatively small, examination of preliminary evidence indicates some cost savings. Short (1988) indicates that economies of scale are present, although the breakdown of costs for mitigation projects and mitigation banks is not provided. Riddle and 
Denninger (1985) show that in terms of construction, design, maintenance, and monitoring, mitigation banking results in a $10 \%$ per acre cost savings when compared to traditional mitigation activities.

Arguments can be made for and against economies of scale associated with mitigation banking. For the developer, the construction cost of the mitigation bank (or any mitigation project) depends on two major factors: (1) the type of mitigation required and (2) the size of the mitigation bank. Differences in the engineering required vary with the type of mitigation needed (i.e., creation, restoration, enhancement, or preservation) and with the activities required to achieve the mitigation. From an examination of mitigation banks and mitigation projects, creation tends to be the most expensive form of mitigation activity, primarily because of the excavation activities required along with the establishment of control structures and the planting of vegetation. Restoration and enhancement projects tend to involve construction of impoundments or breaching of existing control structures and similar barriers; such projects tend to have lower associated construction costs.

There should be no construction cost differences between a mitigation hank and a mitigation project with identical size and engineering characteristics. If, however, we assume the development of a 1,000-acre mitigation bank versus the development of ten 1006-acre mitigation sites requiring the same type of mitigation activities, the potential for economies of scale will be present. The ability to use one comprehensive plan (thus reducing design costs) and the saving of time and effort otherwise spent transferring materials between multiple mitigation project sites should result in declining marginal costs associated with the mitigation bank. However, the presence of economies of scale in construction may vary greatly, depending on the mitigation activities required and the potential difficulties that emerge with the construction of a large wetland ecosystem.

Mitigation banking can provide a cost-effective alternative to traditional mitigation. Greater use of wetland mitigation banking as a policy tool may lead to an increased number of firms specializing in wetland restoration and more entrepreneurial banks being created. As more firms enter the market place, restoration designs and methods will become increasingly more sophisticated and accurate. Increased specialization and experience tend to lower the cost of production processes. Therefore, bank construction cost as well as construction risks should decrease.

\subsubsection{Credit Creation and Pricing}

Mitigation banking operates on the principle that the bank is able to create, restore, enhance, and preserve wetland values; these values can be translated into a credit measure and then used to offset the loss of wetland values from multiple development projects. The wetland mitigation banking system (analogous to the offset and emission reduction system for criteria pollutants of the USEPA, although not identical) attempts to achieve the goal of no overall net loss and to minimize regulatory and economic burdens on developers. To achieve these goals, the 
credit system must have low monitoring and administration costs, provide clear information regarding mitigation costs and banking, and move towards a socially efficient level of mitigation activities.

Two types of credit measurement are currently being used for wetland mitigation banking. The most widely used measurement is based on the amount of wetland acreage (or similar spatial measurement) that is created, restored, enhanced, or preserved by the bank. Through this method, when mitigation impacts require offset, a developer will acquire credits based on a legally or regulator-determined ratio of credit unit to debit unit. No-overall-net-loss of wetland acreage would enable the developer to acquire one credit (assuming the credit covers an acre) from the mitigation bank for every acre of wetland developed (which has not been mitigated on-site). However, regulators have tended to require a ratio of credits to debits greater than $1: 1$.

Several reasons for using credit to debit ratios greater than 1:1 are to (1) reduce the risks of wetland loss, (2) create a higher cost of development through certain sensitive wetland areas, and (3) create a higher cost for the use of differing bank development measures (i.e., creation, enhancement, restoration and preservation). Several states have established ratios that differ on the basis of the type of mitigation activity used to create a mitigation bank or on the type of wetland developed. For those states without legally or regulator-mandated ratios, private developments typically have $2: 1$ ratios, and public development projects have $1: 1$ ratios. Ratios provide a relatively crude means of assessing the credits required to offset developments. In some cases, these ratios have been determined on an ad hoc basis rather than on a scientific basis. This relatively crude method of assessing wetland impacts makes the acreage-based credit systems unlikely to be efficient and may result in the loss of wetland values. However, regulators may prefer the acreage-based credit system because of its accounting and monitoring simplicity. Credit purchase requirements are relatively simple to determine because they are based on area measurements. Monitoring is minimized because the wetland values do not have to be continually assessed.

Valuation systems present at the state level are generally habitat evaluation procedures (e.g., HEP, WET) with greater emphasis on habitat/ecosystem values, as opposed to economic valuation of flood control, water quality, and certain extractive uses. Valuation systems attempt to measure the costs of disrupting a wetland ecosystem and the benefits created by a mitigation project or bank. Lost-value units are then equally compensated by credits based on bank-value units. Unfortunately, the valuation methods are subject to considerable debate. These methods have been challenged on the basis of their inclusiveness of all relevant values and the magnitude they assign to various criteria. Valuation methods are also more costly than simpler acreage-based systems; more short-term and long-term monitoring is required as wetland values change over time, and personnel are needed to supervise such a system.

Valuation systems allow the regulator to achieve the goals of no overall net loss of wetland value with relatively greater certainty. They may lead to a greater level of public confidence in and thus acceptance of mitigation banking. These systems can also facilitate the offset of out-of-kind wetland impacts. Valuation-based systems allow for the recognition of changing wetland values 
over time and can be more valuable to the bank owner if the value of the mitigation bank is expected to increase over time.

When evaluating credit systems, policy makers and bank developers must consider the following factors: (1) the administrative costs of alternative credit systems, (2) the achievement of the socially acceptable level of mitigation, and (3) the comparative value generated by alternative credit systems.

After the debit to credit ratios are determined by the proper regulatory agency, supply and demand determine the price of credits. At present, credits are idiosyncratic in nature; they are not a widely traded commodity. Very few trading institutions exist for exchanging credits and, at least in the near term, the actual drawing of credits has been sporadic (with the exception of DOT-type developments and a few large, private mitigation banks). Regulatory uncertainty over the treatment of credits and banking may also inhibit the development of markets for wetland credits.

\subsubsection{Economic Barriers and Incentives for Mitigation Banking}

From a practical perspective, wetland mitigation banking provides a cost savings to a developer by centralizing the mitigation project locations and reducing permitting and project delays. Given the potential for cost savings using mitigation banking, one would expect mitigation banking to be a more prevalent option for off-site mitigation requirements. Frequently, mitigation banking has not occurred because of regulatory and economic barriers. Regulatory barriers present a more serious restriction to the development of mitigation banking, but economic barriers and disincentives (not directly caused by regulatory interference) should be considered.

The economic barriers and disincentives to wetland mitigation banking include (1) large, uncompensated up-front design and construction costs; (2) uncertain cash flows; and (3) longterm monitoring and maintenance requirements. These barriers and disincentives are accentuated or reduced by the timing of bank development and credit drawdown. Theoretically, these barriers and disincentives (with the possible exception of point 3 ) should not be factors in bank development. However, there can be significant financial hurdles to bank development. Design and construction costs are the largest of all the nonregulatory-related costs of mitigation banking. Assuming preconstruction of the mitigation bank before projects are debited to the bank, the developer has relatively large, up-front costs. For entrepreneurial mitigation banks, the developer may not be sufficiently large to absorb sizable up-front costs that are not compensated for an extended period of time. For public developer/public user banks and single developer/single user mitigation banks, a bank has uncompensated costs in the early part of its lifetime, but the presence of cash flows from other sources can overcome this hurdle. Municipalities and smaller governmental agencies may face funding constraints similar to entrepreneurial banks. Special bond issues, related user fees (e.g., local development taxes in New Jersey, tourism taxes in Florida, or a variation of in lieu fee programs) may be used to overcome initial financing hurdles. For those mitigation banks with some project development (and credit purchases) before and during the 
development of the mitigation bank, the problem of the initial design and construction cost will not be as great a concern.

Another disincentive to the development of entrepreneurial wetland mitigation banks is the uncertainty regarding future cash flows. For public developer/public user and private single developer/single user mitigation banks, the selling of credits is not an important issue because the credits are used to offset their own project development. Because of the relative newness of the commodity (wetland mitigation bank credits) and the regulator-induced risk regarding the ability of potential buyers to access the bank credits in the sequencing process, the growth of entrepreneurial mitigation banks may be slowed. Another factor that may pose problems to mitigation bank development with regard to cash flows is the ability of regulators to limit access to the mitigation hank. Long-term monitoring and maintenance requirements after the bank credits have been exhausted are also a hindrance to the private development of mitigation banking.

Nonregulatory remedies are available to encourage the development of wetland mitigation banking. Planning-oriented, financial, and technical incentives can all serve as means to encourage the private development of banking. Planning-oriented incentives can be implemented through such federal and state programs as Special Area Management Plans and local land-use plans. Financial incentives have primarily involved property tax reductions or tax rebates through the donation or preservation of wetlands and open spaces. Technical incentives come from agency support of mitigation banking activities through scientific assistance.

Land-use planning could entail the establishment of greenways, open spaces, wildlife habitat, and floodplain areas, where land could be zoned for a particular use or given to a developer for the purpose of establishing a wetland mitigation bank. Restrictions on land use in a particular area can encourage the development of mitigation banks as an alternative to other uses. In the past, agencies such as the California Coastal Conservancy and state programs such as the Surface Water Improvement and Management Plan in Florida have encouraged the preservation and establishment of wetland areas to meet a variety of social and ecological goals.

For the private development of mitigation banks, financial incentives are probably the most important of the nonregulatory incentives offered by states and localities. Potentially, mitigation banks, with their typical requirement of existing in perpetuity, could have reductions in property taxes. Currently, wetland preservation by private entities is rewarded through property tax reductions in the states of lowa, Minnesota, and New Hampshire. New York State allows property tax reduction on wetland areas owned by private developers where development is denied. This type of tax will encourage the nondestructive use of wetlands (e.g., mitigation banking). More generally, several states reduce property tax burdens if the owner preserves the land as open space; these states include Connecticut, Delaware, Maine, New Hampshire, North Carolina, Rhode Island, Tennessee, Vermont, New Jersey, Illinois, and Virginia. Reducing the fee simple rights to wetland areas may also reduce the property tax hurden in the states of Delaware, Maryland, New Jersey, Rhode Island, and South Carolina. Local agencies may also allow use-value taxation for wetlands to reduce the tax burden on the basis of how that land is employed. While these taxes currently apply only to preservation, the creation, enhancement, and 
restoration of wetlands to be preserved in perpetuity may receive these tax reductions, especially if the mitigation bank prevents unavoidable wetland losses.

In addition, public agency support through scientific documentation, policy recommendations, and support of the banking concept may speed the more widespread use of mitigation banking. Currently, the USACOE, the USFWS, and regional USEPA offices have provided policy recommendations for the implementation of mitigation banks. The Association of State Wetland Managers has also been involved in the issue of mitigation banking and has issued recommendations for banking development. The activities of these parties may reduce the regulatory risks associated with banking in that regulators will become more familiar with the issues. In addition, scientific research sponsored through a variety of public and private agencies has greatly improved the body of knowledge on wetlands. With the availability of this information, development of functioning wetland mitigation banks is increasing and thus carries less risk (Lewis 1990).

\subsubsection{Risk Factors}

Economic risk relates to those factors that will affect the costs and revenues of the bank because of market forces and unpredicted costs associated with the operation and construction of the bank. Ecological risks and regulatory risks will influence certain costs and revenues, thereby tying these risks to economic risks. The components of economic risk are (1) construction, (2) credit sale, and (3) credit use for internal projects.

\subsubsection{Construction Risks}

Construction risk is the possible and unexpected variance associated with the development of a mitigation bank through creation, restoration, or enhancement. As shown in Figure 3.1, a variety of expenses occur before the mitigation bank is in operation. These expenses include regulatory, site selection and design, and construction expenditures. Regulatory expenditures are addressed under regulatory risks. The other two cost components may be variable. As is the case for other industries, high construction costs may render a project impractical given expected cash flows or they may greatly increase the level of revenues necessary to break even. For cash-poor firms under financial constraints, highly variable construction costs will discourage the development of banks. Construction risks are dependent on economic and site-specific factors. Economic factors include the availability of labor and capital to execute the required tasks. Sitespecific factors include site access and existing site conditions. Factors that may minimize the risks associated with construction include turn-key construction contracts, thorough site examination and evaluation, and assured site access. 


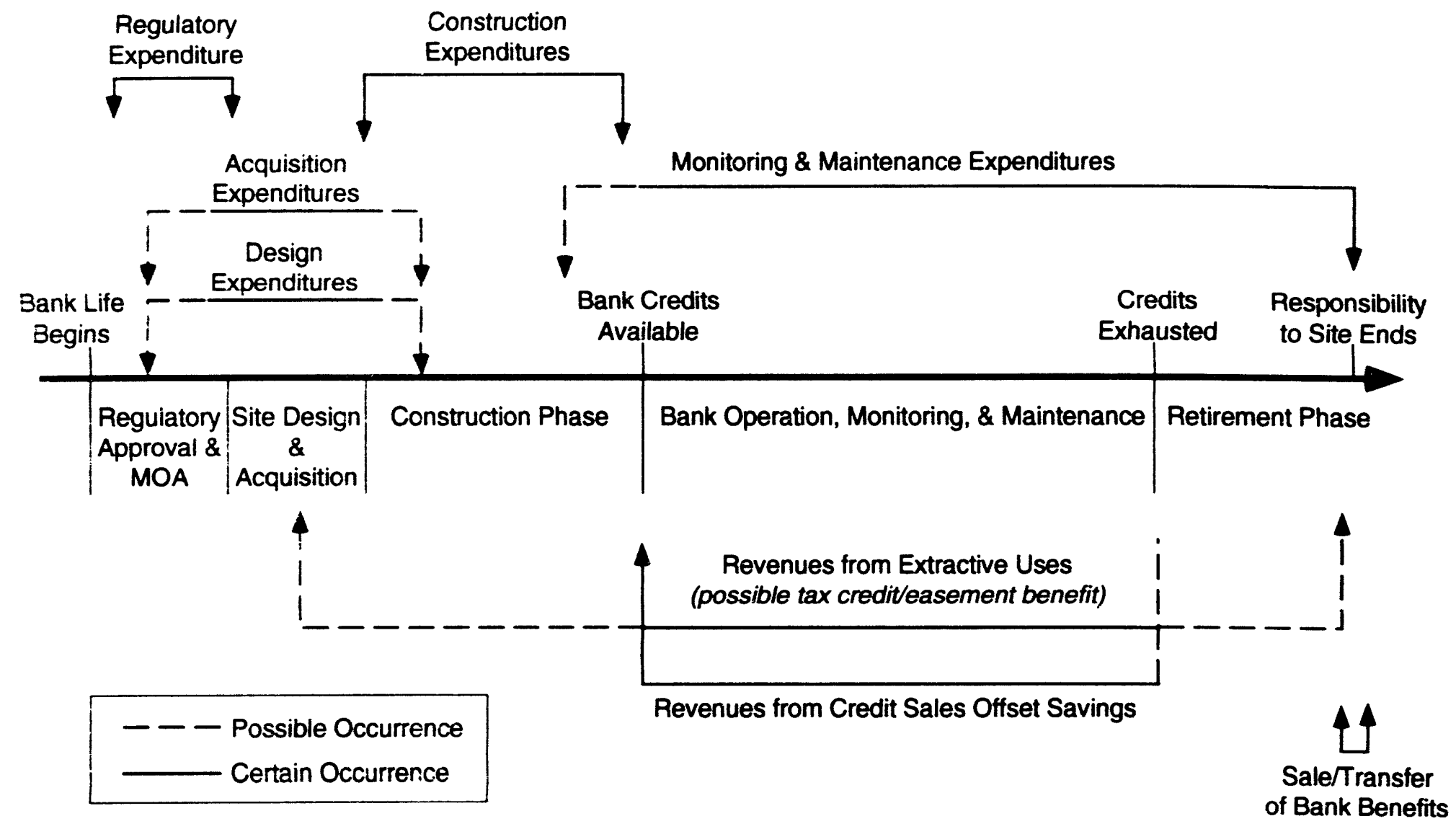

FIGURE 3.1 Mitigation Banking Timeline 


\subsubsection{Credit Sale Risks}

The credit sale risks are primarily associated with mitigation bank cash flows. Some publicly owned and many privately owned mitigation banks have the ability to sell credits internally, to use credits to offset owner developments in or through wetlands, and to sell credits to others. Another possible cash flow results from the developer or third parties using the wetland mitigation bank for commercial or recreation purposes. However, the principal business of the bank is to produce credits for sale; at least, that is how banking is currently perceived.

\subsubsection{Credit Use Risks for Internal Projects}

The inability to sell or use credits for internal projects for the mitigation bank may be caused by economic, biological, political, or regulatory factors. Economic fluctuations may pose the biggest cash flow risks to the bank owner. Slow economic growth or recession will tend to reduce the demand for new development projects. Reduced demand for new projects will reduce the demand for credits, both internally and externally. The consequences of the cash flow risk are obvious. Reduced cash flows may create significant difficulties in debt repayment or make the project unprofitable. The upside of economic risk is increased demand for credits and, hence, increased revenues.

These economic risks are applicable to both public and private mitigation banks. All other things equal, both face the same type of construction risks. The risks to cash flow (revenues) may differ between public and private banks and between different private owners. A mitigation bank used to offset development projects in an industry that is not highly affected by economic fluctuations, such as DOT road developments, electricity transmission lines, and similar activities, would have smaller economic risks. Conversely, a mitigation bank that is used to offset impacts (e.g., a residential housing development) or is set up purely as a entrepreneurial venture to sell credits, will be greatly affected by economic fluctuations.

\subsection{Management and Regulatory Factors}

Section 3.3.1 describes management strategies, memorandums of agreement, and the state and federal permitting process. Issues concerning sequencing, long-term liability, and the involvement of regulatory agencies are discussed in Section 3.3.2. Section 3.3.3 discusses financial risks and potential permitting delays.

\subsubsection{Characteristics}

A common thread among all of the banking management programs is the early recognition of the need for mitigation banking and an infrastructure to manage that need. The management 
structures of the wetland mitigation banks investigated under this program were diverse and closely tied to regulatory considerations. The fundamental document setting up the management structure and interfaces was either the MOA or the MOU. The signatories to the MOA included the developer, state regulatory agencies, federal regulatory agencies, and the bank users. The actual management structure was unique to each bank and was a reflection of the reason the bank was established.

\subsubsection{Regulatory Framework}

The general permitting process for wetland mitigation provides the framework for the concept of banking. The regulatory framework under which a wetland mitigation bank will be permitted and managed defines many of the technical and permitting issues associated with mitigation banking. At the time of this report, all wetland mitigation under the jurisdiction of Section 404 of the CWA was still subject to sequencing. Within sequencing, wetland mitigation banking falls under off-site mitigation; in many cases it is also out-of-kind mitigation and, as such, falls at the lowest rung of the sequencing ladder. Within the off-site mitigation hierarchy, a priori banking is favored over concurrent compensation or in lieu fee programs. However, in lieu fee programs have been used in California and are allowed in Maryland. Some state agencies have recognized that certain ecological benefits can be gained from wetland mitigation banks and have allowed small mitigation projects to use the banks.

In most cases, the wetland mitigation banks that were investigated were set up as compensation for in-watershed wetland losses. However, the definition of a watershed varies greatly. The exact nature of the boundary of a watershed is a function of the regulator's viewpoint and the level of difference in the types of wetlands in different watersheds. In Hillsborough County, Florida, a mitigation bank was planned for each of the three distinct watersheds within the county. The Fina LaTerre mitigation bank mitigates for wetland impacts over the entire Terrebonne Basin. Transco is evaluating the creation of three banks to cover the three major drainage areas in the state of New Jersey. The state banking system in Minnesota allows crossing of watershed boundaries, but only within the DOT district boundaries.

Regulation of wetland mitigation banks occurs at nearly every level of government. The primary federal agencies concerned with mitigation banking regulation are the USACOE, the USEPA, and the USFWS. In some cases, additional federal agencies become involved, including the National Marine Fisheries Service (NMFS), the USSCS, and the U.S. Bureau of Reclamation. At the federal level, the concept of wetland mitigation banking has been investigated at different times by all three of the major agencies. The USFWS investigated banking in its Biological Report 88(41) Mitigation Banking (Short 1988). The USACOE is currently conducting an extensive twoyear study that parallels this study in its content and goals. The USACOE study, which is contracted to the Institute for Water Resources in Fort Belvoir, Virginia, is looking at a broader range of application for mitigation banking, including the role of the USACOE as a regulator and as an impacter of wetlands from dredging and related operations. The USEPA has issued guidance from two of its regional offices addressing wetland mitigation banking. Region IX from 
San Francisco issued draft guidance in March 1992, while Region IV from Atlanta issued draft guidance in June 1992.

Early federal agency involvement potentially may lead to successful wetland mitigation banking. The Fina LaTerre, Inc., Wetland Mitigation Bank was developed with the cooperation of the USFWS. The presence of the agency established a strong currency basis and a long-term management perspective for maintaining the enhancements established by the developer. Another banking-related concept that had early federal involvement was the Walker Ranch Advanced Mitigation Project developed by Disney Development Corporation. Disney Development identified the wetland impacts requiring mitigation on a tract of land to be developed over the next 20 years. By working closely with both the federal and state agencies, a draft 20-year permit was negotiated, with the Walker Ranch property serving as a priori mitigation for the anticipated occurrence of 50 impacts affecting a total of 500 acres over the term of the permit. By involving the federal agencies, a long-term permit was issued, so concern regarding individual permitting actions delaying the development of the Disney property were alleviated.

Twenty-eight states have regulations that provide additional state control beyond the Section 404 requirements. These regulations fall into a variety of legislative categories relating to the areas of water quality and environmental protection. The list of state agencies that are involved with jurisdiction over wetlands yields an idea of the diversity of agencies involved in wetland mitigation. In coastal states, some form of coastal commission has had a role in mitigation. In most other states, the jurisdiction is in the hands of an environmental or natural resource agency.

State regulatory agencies involved in banking include departments of environmental quality or natural resources, wildlife resources commissions, environmental protection agencies, fish and game commissions, coastal councils, land commissions, and departments of conservation. Many of the banks investigated received permits from state jurisdictions under their regulations relating to the CWA. Limited federal involvement in the early stages appeared to allow the bank to gather some state regulatory agency support and momentum prior to entering the federal jurisdiction. Examples of this state-led regulatory approach are the Bracut Mitigation Bank and the Springtown Communities Reserve in California and the Chimento Wetland Mitigation Bank in New Jersey. The Bracut Marsh was regulated almost exclusively on the state level, with the California Coastal Conservancy developing the bank and the California Fish and Game Commission providing regulatory oversight. The Springtown Communities Reserve in Pleasanton, California, has been developed by close coordination with several state agencies that will recognize the reserve as a source of mitigation credits in the rapidly developing Livermore Valley. The Chimento bank has gone through the approval cycle at the New Jersey Mitigation Banking Council with interaction on a federal level from a single agency, the USEPA.

The perception of wetland mitigation banking is rapidly changing at the state level and is not perceived in the same way by all state agencies. Early in 1992, as a part of the task of datagathering, ANL surveyed state agencies to identify the position of the state on wetland mitigation banking. The results represent a single point in time and a limited number of state contacts. According to the survey, four states believed wetland mitigation banking was unacceptable; eighteen states expressed no interest in wetland mitigation banking or regarded the concept 
unfavorably; five states are investigating mitigation banking as an option within their regulations; seven states favor wetland mitigation banking and are preparing or have a pending program for banking; sixteen states either have banking programs in effect or are actually regulating and managing banks. These results will change over time as more federal and state agencies have an opportunity to assess the successes and failures of banks across the country. Changes in the regulations within the states, and potentially even within the federal government, are anticipated to have a major impact on where banking will occur and the likelihood for the effectiveness of a bank in any particular state and for any particular type or system of wetlands.

The involvement of both federal and state agencies in the mitigation permitting and regulating processes leads to multijurisdictional issues and, in some areas of the country, precludes or limits the ability to bank. Individual wetland mitigation banks are usually subject to the jurisdiction of a mix of state and federal agencies. The involvement of the regulatory agencies in wetland mitigation banks enhances bank management for the long term and may case the permitting process for individual actions.

The two banks in operation under the management of the Virginia DOT are subject to oversight by four federal regulators: the USACOE, the USEPA, the USFWS, and the NMFS. There are two state regulators: the Virginia State Water Control Board and the Virginia Marine Resources Commission. Each of these agencies has its own viewpoint when it assesses the withdrawals from the mitigation banks and its own opinion of the values and ratios used in the development of new banking areas.

In the case of the Fina LaTerre mitigation bank, federal and state regulatory agencies take part in managing the bank. The USFWS is involved in setting up the habitat evaluation, and the Louisiana Department of Wildlife and Fisheries is involved in the management and maintenance of the bank.

Another type of regulatory arrangement is a state agency cooperative hank. The state DOT banks are normally set up with the DOT and a natural resource regulatory agency managing the bank. In Wisconsin, the state department of natural resources (DNR) is involved in the DOT Patrick Lake Mitigation Bank. In Idaho, the Idaho Department of Fish and Game is involved in the management of the three DOT tanks. The Minnesota DOT shares the management responsibility of at least one bank with the state DNR.

The regulation of the mitigation banks in this study are as unique as the banks themselves. Regulation comes from all levels of government and through a variety of roles by the regulators. Early involvement of the regulators at either the state or federal level is common to all of the successful banks. Long-term involvement of the regulators during operation, monitoring, and maintenance has proven beneficial to most bank developers. Each bank has recognized the need for regulatory involvement early in the process and has identified those agencies that are amenable to pursuing banking as an alternative to conventional off-site mitigation. By working with the favorable agencies, the developers can gain momentum for the banking concept and can overcome preconceived ideas with regard to the merit of mitigation banking. 


\subsubsection{Agency/Organization Charactoristics}

Department of Transportation Banks. One recurring management system is the operation and use of the banks by various state DOTs. A total of 14 states have DOTs that are involved in both the management and use of wetland mitigation banks: Florida, Georgia, Idaho, Louisiana, Minnesota, Mississippi, Nevada, North Carolina, North Dakota, South Carolina, South Dakota, Tennessee, Virginia, and Wisconsin. A regulator who is well-informed with regard to the compensation being proposed for particular impacts allows streamlined permitting and credit use.

In many cases, the state DOT is a cooperator with a state resource or regulatory agency that provides internal quality control to the banking value and credit system. An exception is the Minnesota DOT, which, in general, manages the Minnesota banking system by itself. The strong internal environmental function within the Minnesota DOT provides quality management for the banks under their jurisdiction. Other DOTs, such as the one in Virginia, manage the banks; keep the records on ratios, credits and debits; monitor and maintain the banks; and propose and create new banks, but they report to an oversight group that approves the credits and debits for each transaction.

Natural Rosource Agency Banks. A second group of banks is managed by federal and state regulatory agencies as well as natural resource agencies. Bracut Marsh, the Port of Los Angeles, and the Port of Long Beach banks in California are managed by such agencies as the California State Coastal Conservancy, California Department of Fish and Game, and USFWS. Similarly, the Company Swamp bank in North Carolina and the Walker Ranch Project in Florida are managed by such resource-related organizations as the Nature Conservancy. These organizations directly establish the mitigation ratios and the currency and credit schemes and perform the long-term monitoring and maintenance of the banks. The natural resource goals of these organizations are a strong environmental component of the bank management and lead, as in the case of Bracut Marsh, to a long-term commitment to restoring degraded areas to higher quality even after banked credits have been drawn down.

County Banks. County agencies have also moved into the management of wetland mitigation banks. DuPage County, Illinois, recognized the development pressure on the remaining wetlands within the county and has taken steps to create a wetland mitigation banking system to serve county agencies and developers. The county government is working closely with the forest preserve districts to incorporate the banks into the existing park system and is providing long-term management for the wetlands after the credit has been drawn down. Hillsborough County, Florida, has also started a banking system to support county-funded development that impacts wetlands. In both cases, the banks are subject to state and federal regulation. MOAs were created to identify the roles of the involved parties and to recognize the lead management role of the county in the banks. 
Clty Banks. Another agency similar to the county in jurisdiction is the municipality. The City of Virginia Beach is in the process of establishing a three-bank system to serve city projects and developers. The city will be responsible for developing the plans, creating the credits, operating, and providing long-term maintenance and monitoring of the bank. Each step of the process is subject to review and approval by a mitigation review team consisting of representatives of the city, the USACOE, USEPA, USFWS, NMFS, the Virginia State Water Control Board, and the Virginia Marine Resources Commission. The City manages the bank, but the review team maintains close control.

Private Banks. Private developers make up another portion of wetland mitigation bank management. Private bank developers are usually closely tied to the users of the bank. The Fina LaTerre bank is managed by Fina LaTerre, Inc., the USFWS, and the Louisiana Department of Wildlife and Fisheries to offset impacts being incurred by Fina Oil Co. in the Terrebonne Basin. Fina LaTerre, Inc., manages the financial aspects of the property and maintains the records for the HEP evaluations. The USFWS has input into the HEP for both the bank and the impacted acreage. EMAX is the manager and operator for the Springtown Natural Communities Reserve in Pleasanton, California. The driving force behind the development of the reserve is the home builder, Kaufmann and Broad. The credits established in the reserve may be used to offset expected impacts in the rapidly developing Livermore Valley. A true entrepreneurial manager is the Chimento Wetland Mitigation Bank in New Jersey. The bank is managed by Associated Environmental Applications for a private landowner. The manager has submitted a development and management plan to the New Jersey Wetland Mitigation Council for approval. Activity in the bank will be subject to review by the council, but the day-to-day operation and maintenance will be provided by the private company. The primary goal will be to maintain quality wetlands to be used by other private sector companies for mitigation projects.

Private Organization Banks. The Walker Ranch Project in Florida is unique in that the Nature Conservancy is taking the lead in managing the property and enhancing the ecological value of the habitats on the site. The project proponent, Disney Development Corporation, is funding the management and improvement to the property, which includes numerous wetlands and several endangered species habitats. The Nature Conservancy will eventually be both the owner and manager of the project and will provide care for the existing and improved habitat.

\subsection{2 lssues and Concerns}

Regulatory agencies play a significant role in influencing the costs of a development project through a wetland. Regulatory requirements imposed on the on-site and off-site mitigation activities can cause delays and create higher costs for the developer. Mitigation banking offers an alternative to rigid sequencing, difficult mitigation requirements, and retroactive mitigation requirements. While sequencing is unlikely to be avoided given the present regulations, a demonstrated mitigation bank may facilitate permitting by providing a proven alternative if on-site mitigation is not available. 
Mitigation banking has high costs at the inception. As indicated by on-site and telephone interviews with bank owners, the establishment of the mitigation bank requires a significant commitment of personnel and time (in some cases up to three years can be spent attempting to establish the mitigation bank). There is a risk that the establishment of a mitigation bank may not be successful. However, as indicated by Disney Development Corporation, Fina LaTerre, Inc., Virginia DOT, and Minnesota DOT, the banks have already, or will in the future, demonstrate significant cost savings because of reduced permitting times, reduced mitigation costs, and reduced delays. The development of mitigation banks by land development organizations, for example, the Irvine Company, seems to indicate that mitigation banking provides a means of reducing regulatory costs.

Mitigation banking may not be a panacea for all wetland development. Traditional mitigation projects may be a lower cost option in terms of development, maintenance, and possibly regulatory costs. Mitigation banking may be best suited for those areas where a window of opportunity exists. The window of opportunity could, for example, include such conditions as the existence of a conservation group who will take long-term control of the mitigation bank; the ability to acquire land near an existing wetland; the use of the land to serve several important wetland functions; the presence of threatened and endangered species on the mitigation banking land; or the ability to ally with a state agency that desires increased wetland habitat. Banks such as Springtown Natural Reserve and Walker Ranch have indicated that alliance with a state agency or conservation group, along with the presence of threatened and endangered species on the proposed bank land, has allowed the mitigation bank to go forward. The ability to discover or develop areas where a window of opportunity exists can result in reduced regulatory costs and easier implementation of the mitigation bank.

The presence of an established mitigation bank can also create a window of opportunity. Additional mitigation was required on a Hillsborough County, Florida, project after development. Unfortunately, the land needed for the mitigation was not owned by the county. The county was required to spend $\$ 1.3$ million to mitigate a three-acre impact because private land in a highly developed area had to be acquired. Currently, the county has implemented a mitigation banking program establishing mitigation banks on public lands.

As demonstrated by DOT mitigation banking programs, the use of a borrow pit as a mitigation bank greatly reduces the cost of road development. After the borrow pit has been created, the incremental cost of gaining greater wetland acreage is frequently lower than the cost of a comparable mitigation project. For large mitigation projects, depending on the surrounding hydrology and property development, the development of a mitigation bank from the mitigation project may be completed at a relatively low cost. This situation presents another window of opportunity where wetland mitigation banking may be a cost-effective alternative to traditional mitigation. However, these wetlands are generally valued lower than some other types of created or restored wetlands.

Wetland mitigation banking has been championed as a solution to the myriad of regulatory issues facing developers who are impacting wetlands. While the concept meets many of the policy goals, mitigation banking does not solve all problems. Regulatory issues concerning ratios of 
mitigation, out-of-kind and off-site mitigation, and multijurisdictional actions will remain despite mitigation banking. However, wetland mitigation banks have demonstrated distinct advantages and disadvantages in dealing with regulatory issues, as described in the rest of this section.

The first disadvantage for mitigation banking is its position in the sequencing hierarchy. The developer must follow a regulatory sequence of actions to avoid or reduce on-site impacts in wetlands: (1) avoid the impacts on-site, (2) minimize the impacts on-site, and (3) mitigate the impacts on-site. These actions are outlined in an MOA between USEPA and Department of the Army concerning the determination of mitigation under the CWA Section 404.1B, Guidelines (Nov. 15, 1989), revised February 7, 1990. Only after these steps have been deemed unreasonable may a developer consider off-site mitigation. In the current regulatory environment, the concept of wetland mitigation banking is considered off-site and often out-of-kind mitigation. Performing mitigation at a bank requires exhausting the sequencing options prior to considering banked credits for use. The need to proceed completely through sequencing puts banking on an equal footing with other off-site mitigation options. The banked credits provide only a limited advantage in shortening regulatory permitting time.

In some areas of the country, wetland mitigation banking is not perceived favorably by state regulators. The basis for the unfavorable perception is that banks will change the ecosystem that presently exists by moving the wetlands out of the basin or subbasin or by changing the type or function of the wetlands within their jurisdiction. In those states, the regulatory position may preclude banking as a mitigation option, especially in the case of linear multiwatershed pipeline projects with state agencies requiring on-site mitigation instead. In addition, universal acceptance of banking has not been achieved across all federal jurisdictions. Banking is developing a positive regulatory framework with certain regions of USEPA and USACOE, but, as of yet, individual districts and jurisdictions may not perceive banking as an option.

Because of the relatively limited experience with banks, regulators are cautious in the approach to credits allowed in a mitigation bank. The ratios and habitat units often include conditions to permit adjustment of the credits. The credit value may be increased or decreased over time to reflect the dynamic nature of wetland ecosystems and the effectiveness or failure of the mitigation project. The regulators also tend to favor enhancement and restoration projects over creation of new wetland acreage. From a regulatory standpoint, this position may limit the type and number of sites that are viable for wetland mitigation banks.

One regulatory issue that requires future consideration is the long-term liability for the credits established within a mitigation bank. Mitigation banking has a reasonably brief history, and maintenance of the credits and the solvency of the operator may be future problems. The bank developer is clearly responsible for maintaining the value of the credits within the banking system at a level that is comparable to the level at which the credits were purchased and drawn down. If a bank operator becomes insolvent, a regulatory question arises as to which party, the operator or the developer who purchased the credits, holds responsibility for the maintenance of the credited areas. This issue of liability has not yet become a problem, but at Bracut Marsh in California, considerable funds have been extended by the owner, California Coastal Conservancy, to maintain and improve the quality of the credits within the bank. The funds have been expended without 
seeking additional funds from the users of the bank. While Bracut Marsh is a relatively small bank, major expenditures at a larger facility may lead to problems. The regulators will want to see the mitigation credits maintain their quality for the life of the impacting project and, quite often, beyond. This iisue touches on all areas of the bank as the ecological design must strive for a selfsustaining system, the banking management must establish a means for the long-term maintenance of the wetland, and the economics must account for long-term monitoring and maintenance of the system. All of these needs are driven by the imperative to have credits maintained to comply with the regulatory requirements.

The first major advantage associated with the concept of mitigation banking is the ability to involve the regulatory agencies at all levels during the early phases of development. The involvement of the regulators in the development stages of a mitigation bank streamlines the establishment and use of the credits. By involving state regulators at an early phase, bank developers have established a regulatory partner, rather than an adversary, to pursue use of the credits with federal regulators. The second major advantage from a regulatory perspective is the minimization of regulatory risk. By creating an MOA that includes the appropriate regulators, all the parties understand what the credit basis is, thereby avoiding the negotiation process for the mitigation acreage. A typical MOA will address the parties involved, the specific definition of mitigation banking, activities for mitigation, geographic size, sequencing, credits/currency, type of wetland evaluation, record keeping, and management/maintenance. The long-term nature of mitigation banking also leads, in time, to a confidence among the regulators that the credits will be maintained. The inclusion of long-term monitoring and maintenance plans also develops a regulatory confidence that the credits will be available and in good condition when drawn down. The third advantage in mitigation banking is that with established credits, the developer stands less risk of needing to pursue mitigation acreage on short notice. While not strictly a regulatory consideration, the ability to have mitigation credit available as a backup in the sequencing procedure may simplify negotiations with the regulators. The bank safeguards against a late change in project plans, which might preclude on-site mitigation and lead to a need for off-site mitigation.

The time frame for permitting depends on the review cycle times for the agencies and the time needed for public input. Special cases in some of the states have significant implications for mitigation banking. In some states, the jurisdiction is at the county, parish, or even forest preserve district level, which may slow the permitting process. The central concept of mitigation banking is to establish the end of the negotiation process first. The mitigation is clearly established, and the developer and agency are negotiating how the anticipated impact fits into the mitigation. Commonly in mitigation projects, the nature of the mitigation becomes the focus of the negotiation and goes through numerous revisions prior to acceptance by the regulators involved.

The most promising regulatory arrangement is the early involvement of both a state and a federal agency. The agencies should become involved as early as possible in the siting stage and should continue to be involved for the remainder of the bank life. Regulatory involvement includes being a signatory to the agreement, participating in the establishment of credits and review of drawdowns, and reviewing and participating in the long-term monitoring and maintenance plans. Involvement by agencies at both the state and federal levels assures adequate attention to 
requirements at both levels. For the oil and gas industries, seeking out state and federal agencies on a particular project or development will be straightforward. In all areas where oil and gas operations have been ongoing, the industry already has working relationships with the state and federal regulators that can be exploited to forward the concept of banking. Historically, Fina Oil Co. has a strong working relationship with state and federal regulatory agencies that closely follows this model.

\subsubsection{Risk Factors}

Regulatory risks are those risks that financially impact the effectiveness of a banking project through the bank approval process, MOA requirements, value measure, credit treatment, allowed trading, bank retirement requirements, and punitive fines. Given the relative novelty of the banking concept for natural resource applications, the greatest risks faced by wetland mitigation bank developers and owners are regulator unfamiliarity with mitigation banking, distrust of the use of a market-based mechanism for addressing natural resource loss, and the risks posed by regulatory purview. Some of the chief financial benefits of mitigation banking are the speeding of the permitting/regulatory process for project development and avoidance of retroactive regulatory mitigation burdens. Some other benefits of mitigation banking are avoiding the unnecessary delays and administrative costs associated with traditional project mitigation.

At present, the chief concern that regulators have about mitigation banking is its ability to fully compensate for development impacts on wetland values. This concern has translated into resistance among certain agencies to permit private mitigation banks. Because some wetland mitigation banking projects, such as Bracut Marsh and Hillsborough County, have failed to develop functioning wetlands and yet credits have already been drawn, certain DNRs feel that mitigation banking is a legal method of avoiding necessary mitigation and sequencing.

Regulators have the ability to influence preconstruction expenditures, construction expenses, operations expenditures, terminal or retirement expenditures, and revenues associated with the internal and external sale of credits. Because of the ability of the regulator to impact the effectiveness of the banking project, it is imperative that the bank owner be able to achieve the goals of the MOA, assure that net wetland values have not been lost, and provide for the long-term retirement maintenance of the bank.

Although institutional impediments are present (along with fears of loss of wetland values through the use of mitigation banking), a variety of mechanisms exist that can address the risk of (1) extensive resources being devoted to the task of permitting projects and mitigation requirements, and (2) excessive delay or restrictions on credit use causing possibly significant economic loss for the developer. Unfortunately, the establishment of mitigation banking may be a resource-intensive process in the near term. As indicated by several mitigation bank developers, the cost of administration and development of the mitigation bank is on the order of two to three times the actual construction costs of the mitigation bank. The regulatory costs associated with bank creation are expected to decrease as regulators become more knowledgeable about banking. 
Familiarity with the banking concept and achievable banking requirements, along with previous successful banking operations, should reduce the risk of excessive burdens in setting up a mitigation bank.

To reduce the risks of excessive delay and restrictions on credit use, various mechanisms have been used or proposed. One means proposed to reduce permitting delay and restrictions on credit drawdowns is the use of a multiyear, multiproject permit combined with mitigation banking. Regulatory risks can also be reduced through agreements for long-term monitoring and maintenance plans. 


\section{Cost Considerations of Current Mitigation Practices and Wetland Banking}

\subsection{Costs of Current OII and Gas Mitigation Practices}

A survey of the oil and gas industry was conducted to gather data on methods and costs for wetland mitigation projects conducted within the past five calendar years. Information collected for each wetland mitigation project included the location and size of the wetland impact, wetland type, mitigation type and area involved, extent of regulatory involvement, and mitigation costs. Appendix $C$ presents details of the mitigation projects.

Separate mitigation cost information was not available for all of the wetland mitigation projects because of the common practice of recording a flat fee per foot of pipeline for gas pipeline projects. Mitigation cost information varies, depending on several factors: (1) location of the wetland impact, (2) type of wetland, (3) presence of threatened or endangered species, (4) type of mitigation involved, and (5) ratio of the area of the wetland impact to the area of the mitigation.

For those projects having mitigation cost information available, wetland impacts were a result of pipeline construction, maintenance, or development, and they were located throughout the United States. These projects were classified under four mitigation types: (1) on-site restoration/revegetation, (2) on-site impact minimization, (3) off-site creation, and (4) off-site preservation. Results of the preliminary survey indicated that wetland mitigation projects in the off-site creation category were generally the most costly.

The 18 on-site restoration/revegetation projects in our survey varied in size from 0.47 to 25 acres, and the mitigation ratios for these projects ranged from 1:1 to approximately 1.5:1. Eighty percent (15) of the projects in this category were located in Pennsylvania or New Jersey. Wetland types mitigated on these projects included bog, marsh, fen, riverine, riparian, scrubshrub, forested, forested riparian, emergent, nontidal emergent marsh, intertidal emergent marsh, and tidal emergent marsh. Mitigation costs of impacted wetland ranged from approximately $\$ 200$ to $\$ 21,300 /$ acre, with an average cost of $\$ 5,300 /$ acre.

The two on-site impact minimization projects for the impacted areas were each approximately 2.9 acres in size and had mitigation ratios of $1: 1$. These projects involved freshwater wetlands located in Pennsylvania and New Jersey. The mitigation cost of impacted wetland ranged from approximately $\$ 350$ to $\$ 5,26() /$ acre, with an average cost of $\$ 2,800 /$ acre.

The size of the impacted area for the three off-site creation projects ranged from 0.92 to 7 acres. The mitigation ratios varied from 1.2:1 to 2:1. These projects were scattered throughout the United States. The wetland types mitigated were forested, low-grade forested, forested/shrub, and palustrine/forested. The mitigation cost of impacted wetland ranged from approximately $\$ 11,800$ to $\$ 50,000) /$ acre, with an average cost of approximately $\$ 24,600 /$ acre. 
The off-site preservation category consisted of one project, having an impacted area of 12.1 acres and a mitigation ratio of 13:1. The wetland was a freshwater, bottomland hardwood swamp located lin Florida, and the mitigation cost of impacted wetland was approximately $\$ 5,200 /$ acre.

\subsection{Docúmented and Anticipated Mitigation Banking Costs}

A survey of mitigation banking costs was conducted for current and proposed mitigation banking developments. Several problems were encountered in this process. One problem was that a large number of banks were in the proposal or early development stages, so no accurate costs were available. Another problem was the absence of monitoring and maintenance costs for many of the mitigation banking sites. Regulatory costs (i.e., cost of delay, cost of personnel devoted to bank establishment, etc.) have been suggested to be major, up-front costs, but no data were discovered on the costs incurred in the regulatory process. Several parties currently involved with mitigation banking indicated that these regulatory costs could be two to three times the construction cost of the mitigation bank.

The mitigation banks were characterized by (1) type of wetland bank (i.e., bottomland hardwood, freshwater marsh, brackish marsh, etc.), (2) type of mitigation activity required to develop the bank, (3) acreage, and (4) cost. This information is provided in Table 4.1 for the banks that were surveyed. The data include costs up to August 1993.

State DOTs have the most experience with mitigation banks and therefore possess the most

data. For many of these sites, a division of costs between construction, land acquisition, planning, maintenance, and monitoring was not available. Data for the Minnesota mitigation banks represent construction, planning, and land acquisition costs. The high costs for the Minnesota mitigation banking sites most likely result from the high cost of land acquisition in developed areas. Those banks referred to as banking systems encompass from 20 to 50 mitigation banking sites.

\subsection{Cost Comparisons and Related Issues}

Mitigation banks have been developed through a variety of engineering techniques and have been established in many different wetland types; thus, the cost of mitigation banking is difficult to assess. For those cases where the banks are archetypes or where several mitigation banks used approximately the same type of wetland development, the costs are known with greater accuracy. The Fina LaTerre mitigation bank combines several mitigation mechanisms through a wide range of wetland types; this development is the largest and, to this date, the most successful private mitigation bank. For the construction, planning, and acquisition of 7,200 acres, approximately $\$ 351,000$ was spent; of the 7,200 acres, 5,000 acres was bankable wetland (the remaining 2,200 acres consists of upland and buffer zones). Monitoring and maintenance over the next 25 years is estimated to cost approximately $\$ 1.5$ million. Another notable mitigation banking 
TABLE 4.1 Characterization of the Surveyed Banks

\begin{tabular}{|c|c|c|c|c|}
\hline Bank Name & Wetland Type & Mitigation Method & Acres & Cost per Acre \\
\hline Aciquia & Palustrine emergent & Creation (from borrow pit) & 21.1 & $\$ 559$ \\
\hline Astoria Airport & Estuarine, brackish & Enhancement & 33 & $\$ 7,200$ \\
\hline Bracut & Saltwater & Enhancement/restoration & 13 & $\$ 27,000$ \\
\hline Dahomey Wildlife Refuge & Forested, freshwater & Restoration/enhancement/preservation & 162 & $\$ 650$ \\
\hline Fina LaTerre & $\begin{array}{l}\text { Freshwater, brackish, } \\
\text { saltwater }\end{array}$ & Restoration/enhancement/preservation & $\begin{array}{l}5,000 \text { for } \\
\text { banking } \\
(7,200 \text { total })\end{array}$ & $\begin{array}{l}\$ 100 \text { for construction, } \\
\text { acquisition and planning } \\
\$ 200-\$ 250 \text { for main- } \\
\text { tenance and monitoring }\end{array}$ \\
\hline Goose Creek & Brackish & Creation & 10.64 & $\$ 6,500$ \\
\hline Mid-City Ranch & Saltwater, brackish & Creation/restoration & 8.2 & $\$ 5,000-\$ 7,000$ \\
\hline $\begin{array}{l}\text { Mn DOT Wetland Banking } \\
\text { Systemb }\end{array}$ & Freshwater & Predominantly creation (excavation) & $1.2-13$ & $\begin{array}{l}\text { Range of } \$ 350-\$ 87,528 \text {; } \\
\text { median is } \$ 9,000\end{array}$ \\
\hline $\begin{array}{l}\text { Mn DOT Wetland Banking } \\
\text { System }\end{array}$ & Freshwater & $\begin{array}{l}\text { Predominantly restoration } \\
\text { (impoundment) }\end{array}$ & $11.3-670$ & $\begin{array}{l}\text { Range of } \$ 18-\$ 113,761 \text {; } \\
\text { median is } \$ 940\end{array}$ \\
\hline Montana Wetland Bank & Riverine & Restoration & 25 & $\$ 1,000-\$ 3,000$ \\
\hline Mudlake Wildlife Refuge & Palustrine emergent & Enhancement & 150 & $\$ 233$ \\
\hline $\begin{array}{l}\text { North Dakota Wetlands } \\
\text { Bank System }\end{array}$ & Prairie pothole & Creation/restoration/preservation & $N^{a}{ }^{a}$ & $\$ 284-\$ 727$ \\
\hline Otterdam & Estuarine & Creation & 14 & $\$ 20,000$ \\
\hline San Joaquin & Freshwater & Creation/restoration/preservation & 24.7 & $\$ 15,000-\$ 20,000$ \\
\hline Stateline/Dead Dog Bog & Freshwater & Restoration/preservation & 320 & $\$ 850-\$ 1,000$ \\
\hline Wet Inc. Mitigation Bank & $\begin{array}{l}\text { Saltwater, scrub-shrub, } \\
\text { hardwood forest }\end{array}$ & Creation/restoration & 2,000 & $\$ 20,000$ \\
\hline $\begin{array}{l}\text { Wetland Accounting } \\
\text { System Bank }\end{array}$ & Freshwater & Creation/restoration & 20 & $\$ 1,000$ \\
\hline
\end{tabular}

a $N A=$ not available.

b This MnDOT system includes approximately 20 wetland mitigation banking sites that have been created.

c This MnDOT system includes approximately 30 wetland mitigation banking sites that have been restored. 
system is the Minnesota system. For this system, mitigation banking acquisition, planning, and construction costs have a wide range: on average, creation of freshwater wetland runs approximately $\$ 9,000 /$ acre, while restoration costs are approximately $\$ 940 /$ acre. These costs should not be taken as absolute values for all mitigation banking projects, but only as representative of costs associated with one state-agency mitigation banking system.

The range of per-acre cost for remediation by conventional means and through use of a wetland mitigation bank are similar. Documented costs for conventional mitigation range from $\$ 200$ to $\$ 50,000 /$ acre. Wetland mitigation banking costs range from $\$ 233$ to $\$ 113,761 /$ acre. The lower end of the cost profile for conventional mitigation is dominated by on-site remediation and restoration. For realistic comparison, wetland mitigation banking costs should be compared with off-site mitigation. Conventional off-site remediation costs exceeded an average value of $\$ 20,000 /$ acre. Only 3 of the 17 banks with documented costs exceeded $\$ 20,000 /$ acre on the average. Most of the banks (13 of 17) had an average per-acre cost of less than $\$ 10,000$. All four of the banks with per-acre costs exceeding $\$ 10,000$ involved creation of wetlands where no wetlands previously existed, at an average cost of about $\$ 19,000 /$ acre. This cost compares favorably with the average conventional off-site creation cost of $\$ 24,600 / a c r e$. The difference is associated with economy of scale. The off-site creation projects were small ( 7 acres or less), while the banks ranged from 1.2 to 2,000 acres.

A significant disadvantage to mitigation banking is the long-term monitoring and maintenance requirements associated with a bank. Typically, traditional mitigation projects have required three to five years of monitoring and maintenance to ensure the function of the site. Mitigation banks usually have the requirement of existence in perpetuity in the MOA. After examining several banks, we found that practically this requirement indicates that the bank must be managed, monitored, and maintained for 10-25 years. After this period, the bank is usually transferred to a state resource agency or conservation group. The long monitoring and maintenance time frame exposes the bank owner to potential large costs. In the event of failure after the bank credits have been drawn down, the owner may incur uncompensated costs. The presence of the long-term risk necessitates proper planning and engineering of the mitigation banking site, which may imply greater initial costs. The risk of long-term failure of the bank, with the owner paying the price of maintaining the bank, creates an incentive for good planning, which is in conflict with the charge that mitigation banking typically results in poor planning and low wetland values. A firm has an incentive to ensure that the mitigation bank operates well in both the short run and the long run because of the risk exposure. The failure of the mitigation bank may also expose both the bank manager and credit user to retroactive regulatory requirements of mitigation.

\subsection{Wetland Mitigation Banking Project Evaluation}

Wetland mitigation bank projects face a number of challenges and risks that are dependent on the bank owner and on the market in which the credits are sold. Although challenges and risks vary with the type of owner and market, evaluation of mitigation banks is similar. In essence, both public and private mitigation banks must consider four major types of expenditures: (1) construction, (2) operational, (3) retirement, and (4) regulatory. The differences and the 
similarities between public and private banks with regard to these four types of expenditures are summarized in Table 4.2 .

Figure 3.1 provides a timeline of a typical mitigation bank lifetime. The life of the bank begins when the owner initiates the bank-approval process with the relevant regulatory parties. Relevant regulators may include state departments of natural resources, environmental protection, and coastal commissions; local/municipal bodies; and federal agencies and departments (such as USEPA, USFWS, and USACOE). The goal of the owner in this phase is to obtain an MOA for the bank. Design and acquisition may be occurring prior to or concurrent with the regulatory approval and MOA phase of the bank. The timing of these phases depends on state requirements and the relationship between owners and regulators.

Next, construction of the site begins. Construction can entail multiple tasks, including excavation, impoundment, access creation, and vegetation establishment. At any time after construction is complete and the goals set forth in the MOA have been achieved, the bank begins operation. During the operational lifetime of a bank, credits may be accrued, sold, or used internally. After site acquisition, revenues can potentially be generated from extractive uses: fish and game esources can be taken from the site and sold in the market. These resources can potentially create revenues from the time of site acquisition until the site is sold. During the operational phase of the bank life, monitoring and maintenance of the site are required. Monitoring and maintenance serve as tools to evaluate goals set forth in the MOA, measure the value of the site for assessing credit levels, and ensure that the site is in good working order.

After the credits have been exhausted at a site, a bank enters its retirement phase. The owner is required to monitor and maintain the site for the number of years stated in the MOA. No revenues from credit sales are available unless reevaluation of the site indicates that additional credits have been created. At the end of the retirement phase, if the original owner is not required to maintain the site in perpetuity, the site may be sold or transferred to another party. The sale or transfer could generate revenue, goodwill, or tax reductions.

\subsubsection{Evaluation of Public and Private Wotland Mitigation Banking}

A major difference between public and private mitigation banks is found in the benefit and revenue streams. Public banks have been implemented to reduce the cost of mitigation, speed the development process, and improve wetland values. Because of the need to consider all benefits and costs associated with mitigation banking, a cost/benefit analysis may be used as a tool for evaluation. However, private mitigation banks must consider issues of credit sales, internal use of credits, and cash flow. Fluctuations in cash flow and credit sale may cause private banks to fail. Because public banks are tied to infrastructure projects (road, airport, port, sewer), they are not as dependent on market fluctuations. In cases where public banks are to be used to provide credits for private development (DuPage County and possibly future Virginia Beach banks), cash flow is 
TABLE 4.2 Comparison of Cost, Risk, and Evaluation Considerations for Private v8. Public Banks

\begin{tabular}{ll}
\hline \multicolumn{1}{c}{ Item } & \multicolumn{1}{c}{ Consideration } \\
\hline $\begin{array}{l}\text { Similar costs or risks for } \\
\text { public- and private-owned } \\
\text { banks }\end{array}$ & $\begin{array}{c}\text { Construction Expenses } \\
\text { Site selection } \\
\text { Design } \\
\text { Site acquisition } \\
\text { Excavation/impoundment } \\
\text { Biological establishment } \\
\text { Operational Expenses } \\
\text { Monitoring } \\
\text { Functioning/improvement } \\
\text { Retirement Expenses } \\
\text { Monitoring } \\
\text { Improvement/contingency fund } \\
\text { Regulatory Expenses } \\
\text { Bank establishmentMoA } \\
\text { Credit transfer overview } \\
\text { Ecological Risk }\end{array}$ \\
\hline Factors unique to bank type \\
Public
\end{tabular}


important, but not key, to the survival of these projects. Evaluation of public and private mitigation banking will differ due to the focus of public versus private interests and the differing impacts of various cost, revenue, and risk considerations.

\subsubsection{Evaluation of Public Wotland Mitigation Banks}

As indicated above, mitigation banking is being used by public agencies to speed mitigation, increase (or maintain) wetland values, and lower costs associated with development in wetlands. The public owner must consider (1) the costs associated with the creation of a wetland mitigation bank, (2) the cost savings (benefits) to development projects through use of the bank credits, (3) the possible savings to private agents using credits from the bank, and (4) the relative change in wetland values. Expenditure and savings criteria should be considered within the cost/benefit analysis for public banks. The value of wetlands depends on wetland functions being perceived as contributing to the public good and on the common-property nature of many of its products. For example, mitigation banking and development through wetland areas will alter flood control and water purification for a locale and will alter property values. Also, threatened and endangered species may be preserved and more habitat created by the mitigation bank. Clearly, preservation of such species has been considered a public good. Wetlands also produce commercially harvested aquatic and terrestrial commodities, which in many cases are commonproperty resources. For examples of applying cost/benefit analysis, see Anderson and Rockel (199()), Krutilla and Fisher (1985), and Freeman (1979).

\subsubsection{Evaluation of Privato Wotland Mitigation Banks}

Wetland mitigation banks resemble capital projects in several ways. There is a planning phase, with design and siting expenditures, followed by a development or construction phase, in which a site is acquired and developed. After construction, the bank has a useful lifetime during which credits are drawn. Associated with the operational life of the bank are monitoring and maintenance expenses to keep the bank in good order. In the retirement phase, the bank credits have typically been exhausted, and the wetland is maintained or transferred.

The evaluation of a bank requires the assessment of costs and revenues in all phases of its life. One policy aim of banking is to reduce development costs by consolidating mitigation requirements. For example, establishing a bank prior to development may reduce regulatory cost and avoid associated on-site mitigation costs. Instead of performing expensive on-site mitigation, the developer could draw credits from a bank to offset impacts of the development. A sample evaluation spreadsheet (Table 4.3) addresses the various costs and benefits associated with a banking project. A hypothetical banking project analysis is presented in Section 4.4.2. 


\section{TABLE 4.3 Sample Wetland Mitigation Banking Spreadsheet}

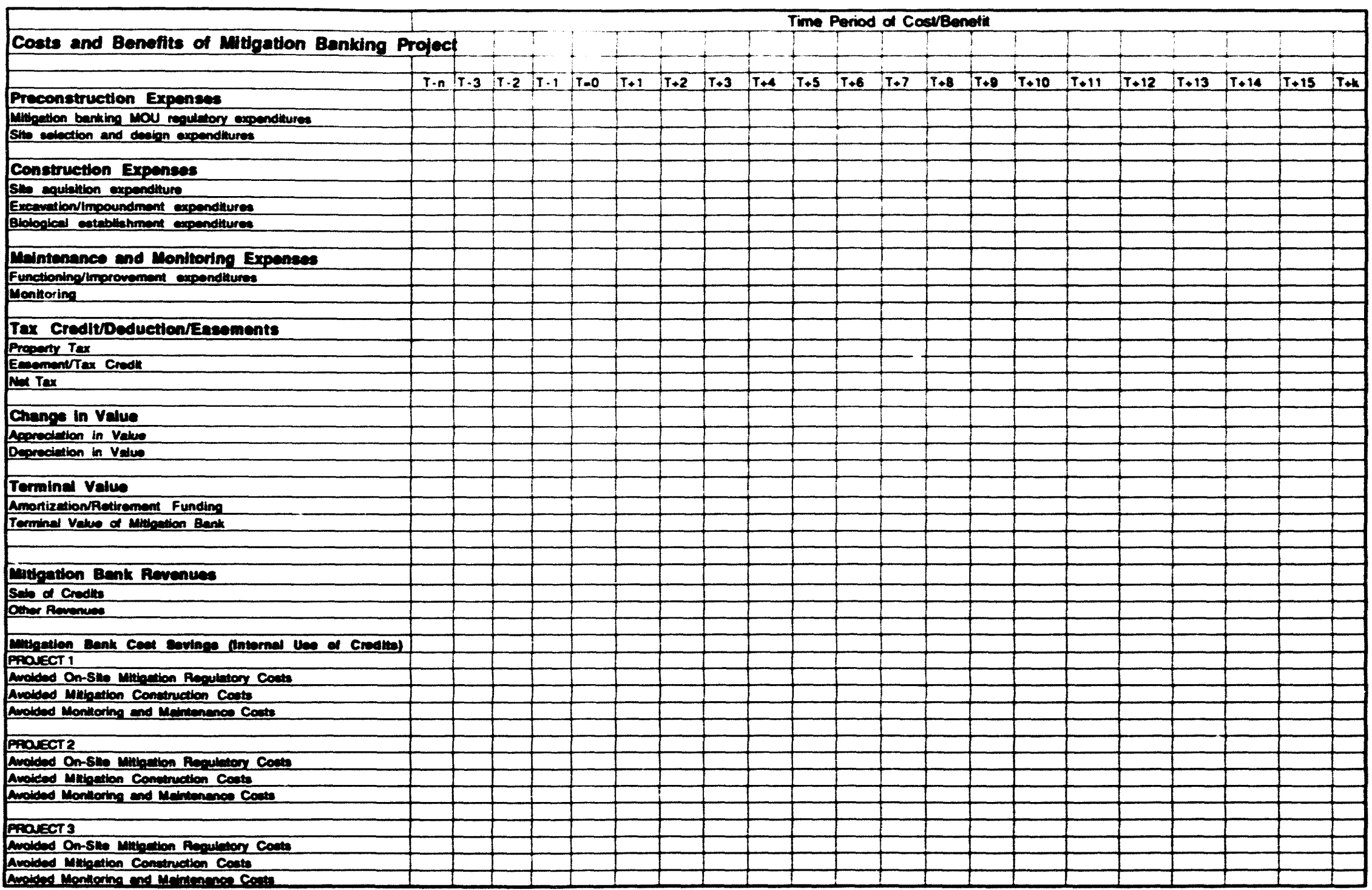




\subsubsection{Timing of Costs and Rovenues}

The life cycle of a bank varies with its location and type. The bank lifetime is a function of time spent in preconstruction activities, operational life, and retirement period. Time required for preconstruction activities depends on both market conditions and regulatory requirements. The operational lifetime of a bank will largely depend on market forces (for private banks) and on the number of wetland impacts (for public and private banks). The length of the retirement phase is dependent on the MOA. Therefore, project evaluation spreadsheets include a range of time periods reflecting the varying life spans of bank projects.

\subsubsection{Exponditures}

Preconstruction Expenditures. Major expenditures associated with the preconstruction phase are the mitigation bank MOA costs and the site selection and design costs.

The creation of a private bank is currently a long and difficult process, even in those states with tacit or demonstrated approval. State DOTs have shown greater effectiveness than private entities in achieving regulatory approval of mitigation banks, as have a growing number of municipal/local development projects. The successful negotiaiton of an MOA and approval of a banking project typically requires coalitions among local, state, and federal agencies with private groups. If a private developer(s) can gain a blanket MOA covering all banking projects in an area, the average cost of this process will decrease.

Site selection and design can be a time-consuming and expensive process. The site selected will directly influence ecological, political, and economic effectiveness and, hence, the eventual approval of the bank. Such factors as hydrology, adjacent buffer and wetland areas, presence of threatened and endangered species, access, and design parameters all play roles in site selection.

Construction Expenditures. Obtaining data on the individual components of wetland mitigation costs is difficult. Typically, mitigation costs have been combined with total project development costs. Cost breakdowns were not available for most of the banks examined.

There are three major construction expenditures: (1) site and access acquisition, (2) excavation and impoundment, and (3) biological establishment. The expense of site acquisition largely depends on prevailing local property costs and the availability of candidate bank sites. Bank construction entails placing controls on a water source to comply with the hydrologic design. In general, site excavation associated with wetland creation is more expensive than impoundment. Construction expenses will also include a cost for access to the site and the mitigation expenditures associated with access. 
Finally, vegetation establishment expenses must be considered. Depending on the site chosen and the requirements of the MOA, the cost varies widely. For example, the impoundment and restoration of low-lying agricultural fields to wetlands may require little new planting. For wetland creation, planting of numerous wetland species by hand could be required over a long period of time.

Malntenance and Monitoring Expenditures. Following the construction phase, maintenance and monitoring of the site is required. As can be seen from the survey of existing banks, all the sites required additional maiıtenance actions after construction. The site may require altering hydrology, replanting species, regrading, or removing invasive species.

Maintenance and improvement expenditures are subject to significant variability. Although wetland science has progressed significantly over the past decads, establishment of ecological systems is still uncertain. Failure to achieve benchmark ecological goals may result in delayed bank use, further improvement expenditures, and possible restrictions on bank use. At present, the greatest assurance against failure is proper site design and construction. Even if no major problems occur, additional improvements on a periodic basis may be required by the MOA.

In order to properly maintain the bank and to correct problems, regular monitoring must be performed. The monitoring function also evaluates the effectiveness of the mitigation bank. A variety of tasks may be required, including ecological assessment of water quality, groundwater and surface-water levels, biodiversity, and wildlife populations. Monitoring may also include valuing the productivity of the site for the purpose of establishing credits. Regular monitoring of the site can be beneficial to the owner. The Minnesota DOT monitors sites to ensure that the wetland is functioning as designed and to assess changes in value. During site visits to MnDOT systems in Minnesota by ANL personnel, several sites were found to be more productive than previously indicated, allowing more credits to be drawn.

\subsubsection{Tax Credit/Deduction/Conservation Easements}

In certain states and localities, property tax credits are given for preservation and reestablishment of natural areas (World Wildlife Fund 1990). Because bank owners and users are sometimes required to pay property taxes, tax credits and conservation easements can lower these taxes.

\subsubsection{Value}

Changes in Value. Credits available for use fluctuate over time because of the dynamic nature of wetlands. Regulators will require maintenance of some minimum level of value and 
require that bank debits do not exceed credits. Monitoring and maintenance ensure that the value of the bank does not depreciate.

Torminal Value. After the bank credits have been exhausted, the owner is required to maintain the bank for some predetermined period of time, probably for a number of years. Also, the bank may be salable. The monitoring and maintenance expense in the retirement phase could be viewed as an annuity if the bank is required to be maintained in perpetuity. For a shorter retirement phase, a sinking fund may be established to cover the monitoring and maintenance expenses, or these expenses may be paid out on a year-by-year basis. The owner may be exposed to considerable financial and regulatory risk if the bank is required to be supervised and maintained for extended periods of time. Failure to maintain the bank may result in punitive regulatory measures and additional cost expenditures for maintenance after the bank credits are depleted.

Banks may also have a terminal value. The property may be salable to other agents, generating revenues, or it may be donated to a private trust, generating a tax deduction and possibly creating such indirect benefits as public goodwill. Transfer to another party may also allow the original owner to reduce risks associated with long-term maintenance and monitoring.

\subsubsection{Revenues}

Mitigation Bank Revenues. The principal product of a bank is its credits. Depending on the goals of the owner and the MOA, credits may be used to compensate development by the owner or be sold to others. Revenues are subject to both market and regulatory risks. Market risk is a function of national and regional economic conditions and development within the crediting area of the bank. Reduced demand for credits will reduce revenues or potential savings attributable to the bank. For example, even if poor economic conditions delay pipeline development for several years, construction and operational expenditures still have been made, and cost savings attributable to the bank are delayed or reduced. Optimally, the bank is established so that its credits can be completely sold, thereby maximizing economic benefit for the owner/developer.

Revenues are also subject to regulatory risk. Strict sequencing requirements, restrictions on the type of projects mitigated, and conflict over available credits will reduce bank revenues and cost savings. Minimizing regulatory risk is perhaps the most difficult problem for owners and developers.

Revenue from Credit Sales. A few of the existing private bank owners sell credits to third parties. This ability increases the pool of potential buyers, which makes the bank more valuable to its owner. 
Revenue from Savings. The majority of existing and planned banks are used to reduce on-site mitigation costs and to speed the regulatory process. Credit sales can be dealt with in two ways. In the first method, a bank can be treated as a separate financial entity, and the owner is required to buy credits representing a transfer of resources from the development part of the firm to the bank. The price paid for the credit may reflect the market value, the avoided costs of on-site project mitigation, an average-cost pricing method, or other pricing method. Separate assessment of credits and debits allows the owner to evaluate the variety of opportunities available for credit transfer. In the second method, credits are simply be transferred between departments of the financial entity.

Other Revenues/Benefits. Wetlands are highly productive ecosystems providing numerous commercial goods and recreational values. They serve as aviaries, mammal habitat, and fisheries. Bank owners may be able to capitalize on these values through harvesting or leasing the rights to these resources.

\subsubsection{Treatment of Risk in the Evaluation of a Development}

Risk is present in a variety of forms in mitigation banking. A sensitivity analysis is required to assess the impact of various cost and revenue factors on the cash flow of a development. In the following example, break-even analysis and expected net-present-value (NPV) are used to assess a hypothetical mitigation bank. Break-even analysis is defined as an analysis of the level of sales at which a project will break even (Brealey and Myers 1990). When using expected NPV, probability levels are assigned to various expenditures and revenue flows. The assumptions made to demonstrate how the break-even analysis is applied to a hypothetical wetland mitigation bank are as follows:

1 credit $=1$ acre

Development of 500 acres occurs, which must be established before credits are drawn Maintenance and monitoring must occur from operation to retirement

Present value (price) per credit $=\$ 800$

Site acquisition and construction costs $=\$ 220,000$

Initial regulatory costs $=\$ 30,000$

Retirement funding $=\$ 50,000$

Maintenance costs $=\$ 50,000$

Monitoring costs $=\$ 15,000$

Continuing regulatory costs $=\$ 10,000$.

In this case, we assume that construction, maintenance, and monitoring expenditures accrued are not dependent on sales; they are not variable costs directly associated with the use or sale of credits. Assume the opportunity cost of capital is reflected in these costs. The assumption that these costs are fixed is reasonable if the bank is required to have a set level of ecological effectiveness before credit sales are allowed. The total-present-value of costs is $\$ 375,000$. As 
illustrated in Figure 4.1, the break-even point for the project occurs when 468.69 credits are sold. If the price of credits is variable, a price of $\$ 700$ or $\$ 1,200$ is assumed, and the break-even level of credit sales is 536 or 312.5 , respectively. If the credit price is $\$ 700$, the bank is clearly not profitable (its NPV $<0$ ).

A stepped-cost representation may be used if the bank is not required to make expenditures on acreage until sales are made or a use agreement is established. A continuous cost function can be portrayed if purchased credits require incremental improvements on the bank acreage. For example, assume that the bank owner expands the bank in 50-acre blocks. The cost of acquiring the 500 acres is $\$ 100,000$. The other present-value-costs are as follows:

$$
\begin{aligned}
& \text { Construction cost }=\$ 240 / \text { acre } \\
& \text { Initial regulatory cost }=\$ 30,000 \\
& \text { Retirement funding }=\$ 50,000 \\
& \text { Maintenance cost }=\$ 100 / \text { acre } \\
& \text { Monitoring cost }=\$ 30 / \text { acre } \\
& \text { Regulatory cost }=\$ 20 / \text { acre. }
\end{aligned}
$$

The resulting break-even graph is illustrated in Figure 4.2, where it can be seen that the break-even points are identical to those of the previous example (shown in Figure 4.1). Assuming each credit is predicted to sell for $\$ 800$ and that maintenance costs increase to $\$ 150 /$ acre, the breakeven level of sales is at 500 .

To address potentially variable cash flows within the net-present-value equation, probability weights can be assigned to inflows and outflows (for example, to certain monitoring expenses and sales), as presented in Table 4.4. Monitoring expenditures may be uncertain due to variance in the effectiveness of the ecological establishment. We assume that a .33 probability exists that costs are $25 \%$ more than estimated; a .33 probability that costs are $25 \%$ less than estimated; and a .33 probability that costs are identical to the projections. Therefore, the expected monitoring expenditure for each year is $\$ 990$. Revenue from credit sales is assumed to vary due to market uncertainty. Assume that there are four possible credit-sale outcomes and that each has an equal likelihood of occurrence. The possible outcomes are (1) sales 50\% lower than expected, (2) sales $10 \%$ lower than expected, (3) sales equal to expected value, and (4) sales $25 \%$ greater than expected. The expected level of cash flow from credit sales is as follows:

$\$ 10,950$ in year 1 of the project

$\$ 36,500$ in year 5

$\$ 22,812.50$ in year 7

$\$ 45,625$ in year 9

$\$ 45,625$ in year 10 . 


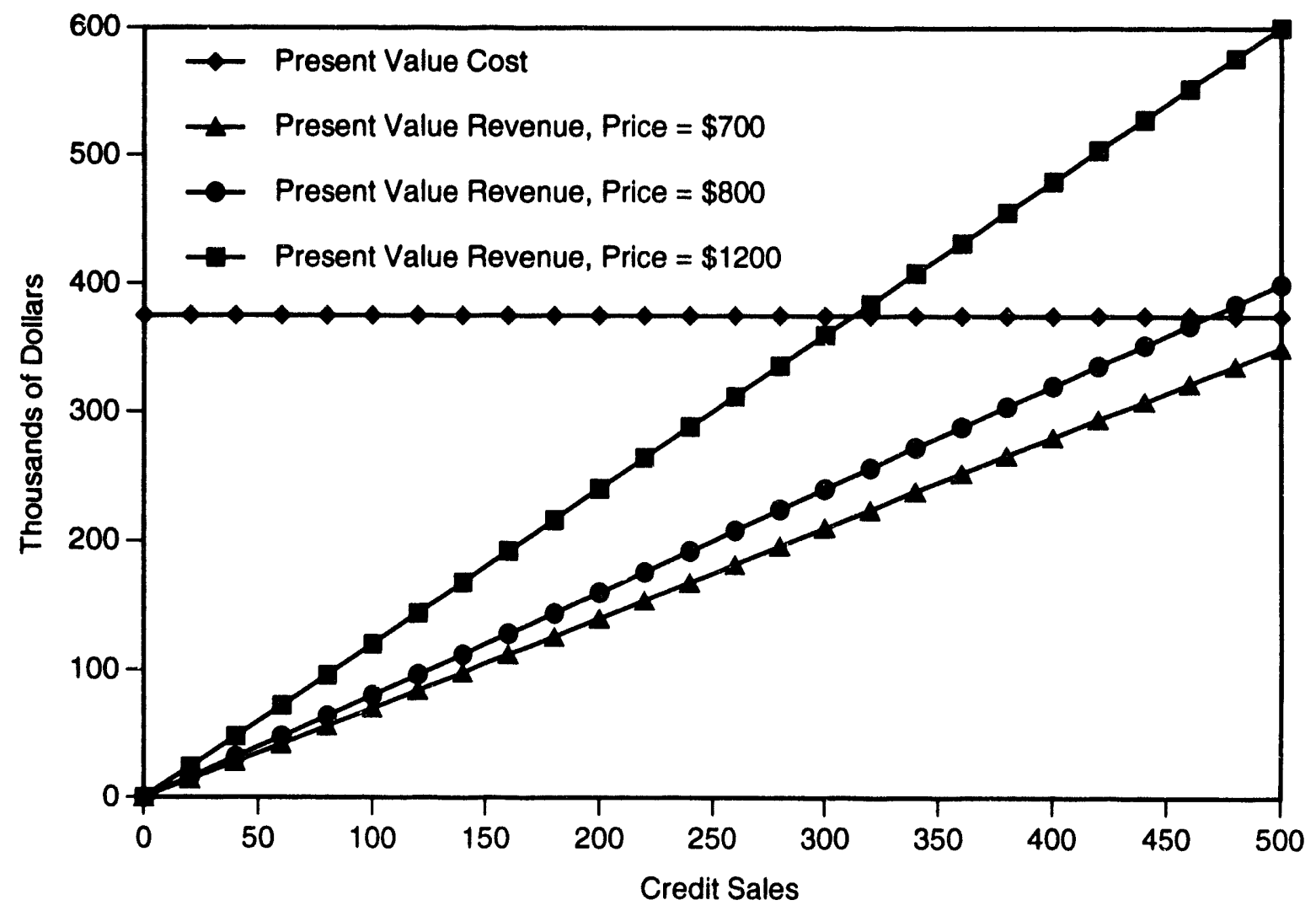

FIGURE 4.1 Break-Even Analysis Assuming Variable Revenue

Assuming that the rest of the variables do not vary significantly from the estimates of Table 4.4, the impact of these changes is indicated in Table 4.5. As can be seen, the NPV of the project decreases over time.

An even more detailed analysis could use a Monte Carlo simulation to consider all the possible combinations of cash inflows and outflows. A Monte Carlo study or simulation is used to estimate a desired population characteristic through drawing random samples of a population repeatedly. Through repeated random sampling, a pattern of population distribution emerges. In essence, the calculation of expected net-present-value, E[NPV], would be

$$
\begin{aligned}
\mathrm{E}[\mathrm{NPV}]= & \mathrm{E}[\text { (credit price }+ \text { value of offsets }) \times(\text { available credits })+\text { other income }] \\
& -\mathrm{E}[\text { construction costs }+ \text { operations costs }+ \text { retirement costs } \\
& + \text { preconstruction costs }] .
\end{aligned}
$$

The simulation model would ideally include a set of equations for each variable (e.g., construction costs, MOA costs) that would include correlation among variables and across time. 


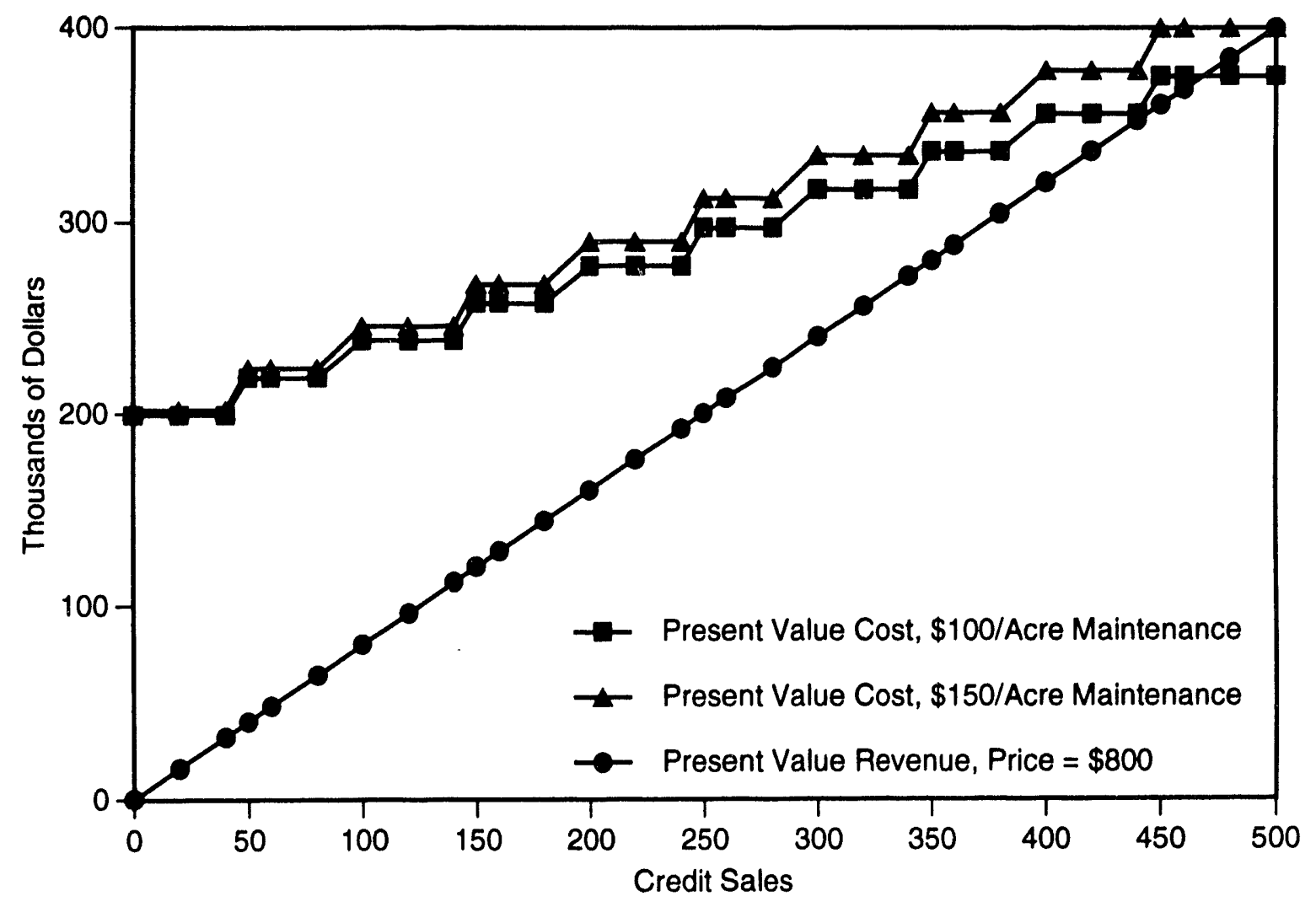

FIGURE 4.2 Break-Even Analysis Assuming Variable Maintenance Cost 
TABLE 4.4 Sample Wetland Mitigation Banking Spreadsheet Including Representative Cash Flows and Costs

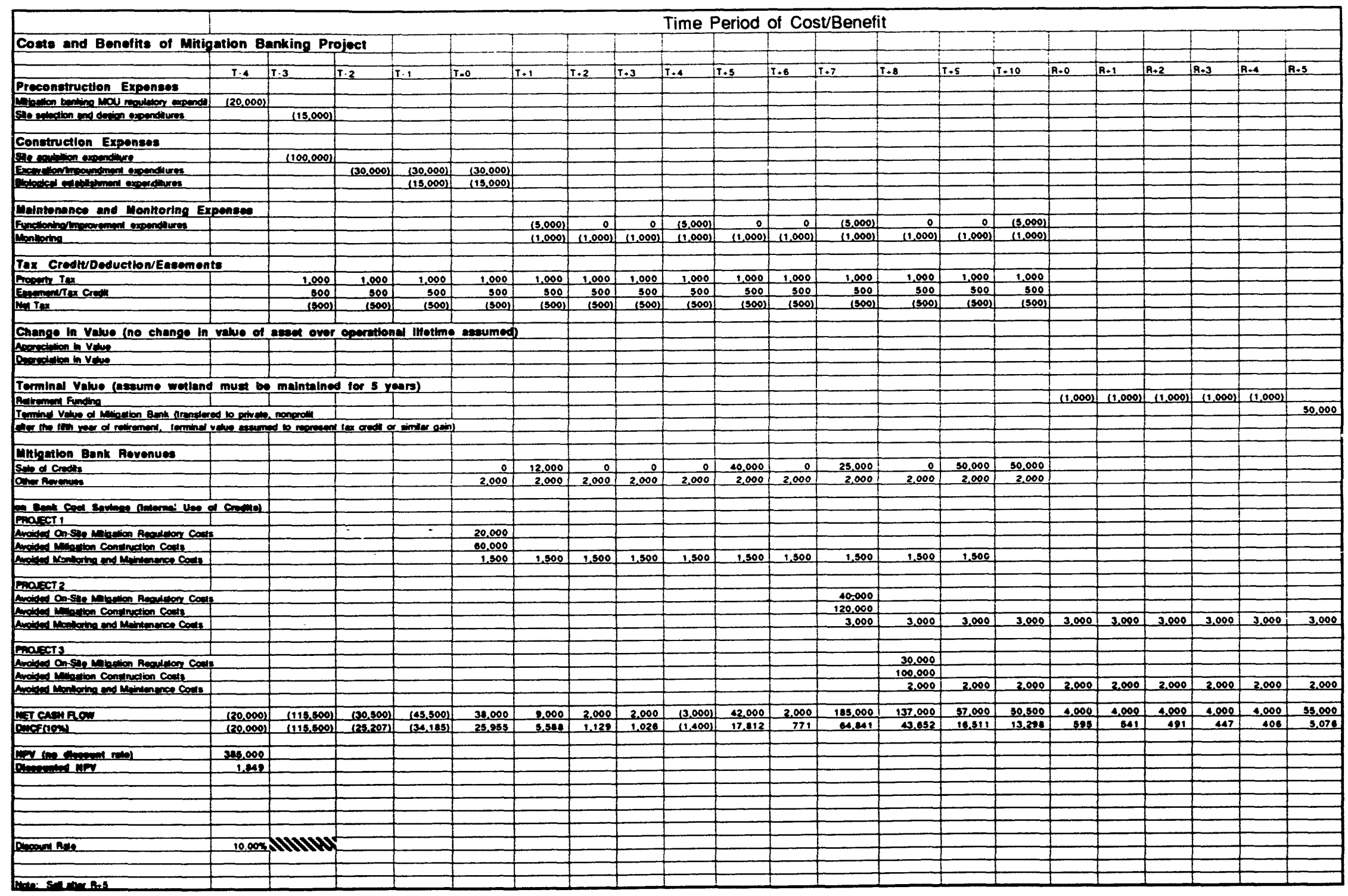


TABLE 4.5 Sample Evaluation Spreadsheet with Representative Cash Flows and Variations in Costs

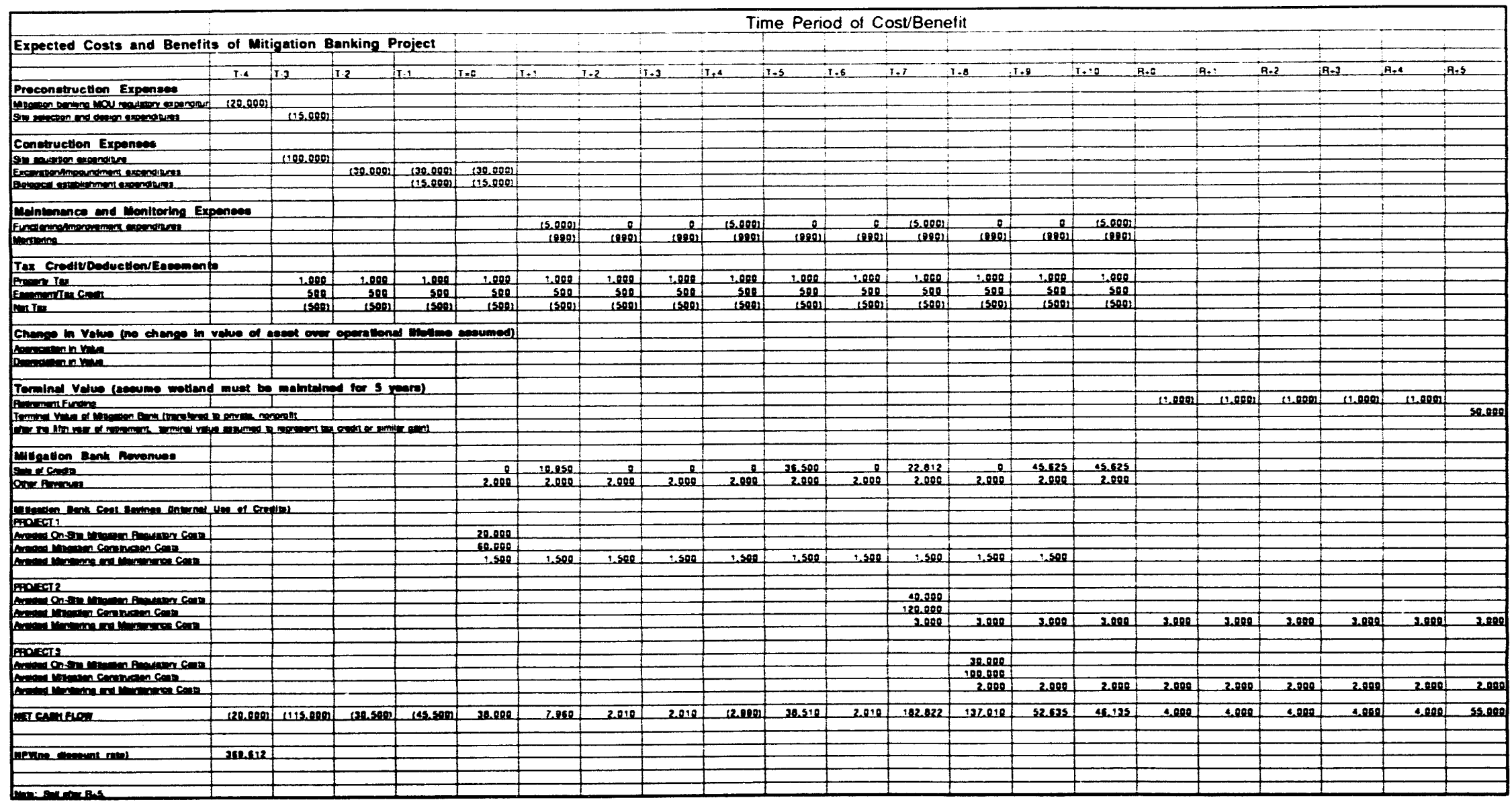




\section{Conclusions and Recommendations}

\subsection{General}

The conclusions and recommendations have been grouped for discussion into four categories - (1) ecological, (2) economic, (3) management, and (4) regulatory - according to the major thrust or major area of impact. These categories should not be considered mutually exclusive.

\subsubsection{Ecological}

The ecological and technical success of a bank must be considered primary to the overall success of the bank. The following conclusions and recommendations provide guidance for a developer's or user's approach to the ecology of wetland mitigation banking.

Only a priori banks fit the definition of wetland mitigation banking. Concurrent credit use and in lieu fee programs are distinct from true banks. However, a priori banking is not the only type of coordinated off-site mitigation project. In lieu fee programs and compensatory projects can result in the creation of an a priori bank. These types of programs have fundamentally different issues associated with their implementation. They offer an option to conventional mitigation and need to be evaluated separately from wetland mitigation banking in terms of how they are capitalized, managed, and implemented. One of the major issues associated with these alternative programs is how they accomplish compliance with no overall net loss and the warranty of effectiveness without having an established wetland value as a credit base. Some states broaden the definition of banking to include these other forms of coordinated off-site mitigation. Nevertheless, the potential role of concurrent and in lieu fee programs in getting banks initiated should be carefully considered by the industry.

Under the present regulatory climate, banking transactions are generally limited to exchanges involving comparable wetland functions within the same drainage basin and ecoregion. Transactions across functions and regions are possible if the total wetland values are conserved. However, up to this point, institutional barriers and scientific uncertainties bave hindered application of off-site mitigation, including banking.

Wetlands being used as banks should not be limited in their credit or acreage to only the area occupied by jurisdictional wetlands. Recognition of the buffer and transition areas as a part of a larger ecosystem that helps maintain the wetland function is necessary. Isolated wetlands having no continuity with the ecosystem are clearly of lesser value than a wetland that is integrated within the ecosystem. 
Banks should be planned on the basis of modest goals for wetland functions. Higher order functions (e.g., preserving endangered species habitat) are difficult to justify economically because the certainty of achieving those functions is low. As a result, bank creation and regulation should focus on functions with high likelihood of effectiveness, or strategies should be developed for systematically adjusting estimates for risk and values.

\subsubsection{Economic}

For a bank to be viable for long-term mitigation use, the economics of the bank must be sound and well-structured. The following recommendations and conclusions provide insight on how the economic structure of a bank can promote success.

Equitable transactions are only possible when they are based on fundamentally sound currency. The currency must also be understood and accepted by the subject parties of an MOA. Without established and accepted currencies, banks become a series of individual mitigation actions subject to negotiation of exchange rates, individual value assessments, and piecemeal development; the economies of the bank, including reduced approval times, would not be realized in this situation.

Currency may be established on the basis of wetland functions, wetland values, regional wetland needs, acreage, and habitat value. The currency must be consistent and acceptable to the bank manager, the regulator, and the bank user. Establishing quantitative values for wetland functions is a difficult task that requires a cooperative effort on the part of all parties to an MOA. Such simple currencies as acreage are not without dispute, because of a perception of the value of different types of acreage. Exchange ratios tend to be subjective and imply an assessment of functional value and of uncertainty in mitigation.

Whereas currency for banking transactions must be formally developed and implemented, exchange of currency among banking participants can be accomnıodated by a market for such exchanges. As a result, credits in banks may be purchased for fair market value by parties wishing to use those credits on development projects affecting wetlands elsewhere within the region served by the bank. Market prices for these credits serve to ration the distribution of wetlands development benefits. Only at this level of policy sophistication does wetland mitigation banking policy approach its analog of air emissions banking.

Positive values of wetland developments and temporary impacts must be fully accounted for within banking transactions. While these are not always recognized, positive changes in wetland values are created by some development projects through enhancing an existing function or adding a new function. In addition, some development projects will return to their natural states over time, implying no loss of functions or values. If the wetland loss associated with a project proves to be temporary, the loss need not be mitigated in perpetuity through wetland banking. Rather, the level of mitigation should be a finite amount based on the temporal losses associated 
with the project. If full compensation is debited at a bank, the difference will be a positive wetland credit that can be used to offset other, future impacts.

Wetland values in a mitigation bank do not need to be fully developed to initiate credit use. Wetland mitigation banks, if properly designed, will have value early in their development. Tte value of the bank will generally increase with time, permitting credits to be taken as the mitigation bank increases in value. Recognition of the value curve permits early use of credits and an increase in bank value over time.

\subsubsection{Management}

A sound management structure is key to maintaining the ecological, regulatory, and economic success of a bank. As a developer or user approaches banking, the following recommendations and conclusions need to be considered in evaluating how the bank management may affect the success of the bark.

Banking programs that have fully developed and agreed-upon systems of currency, transactions, and management are less dependent on mitigation ratios. No rational basis for mitigation ratios exists where total wetland values are conserved and where banks can be maintained in perpetuity. At most, mitigation ratios can be justified as a factor of safety to adjust for programmatic weakness in any of these areas. However, any inconsistency in the use of mitigation ratios in conjunction with a banking program could undermine the viability of banks and stifle their development.

A standard MOA for creation of banks needs to be developed and must be implemented for as many jurisdictional levels as possible. A standard MOA can reduce regulatory risk associated with bank development, achieve consensus on banking program goals and approaches, and establish the vasis for bank operation well beyond the exhaustion of credits exchanged through transactions.

Management of banks must be maintained in perpetuity, until natural processes are projected to diminish or deplete the value of the wetland, or until the wetland becomes selfsustaining. Banking proposals need the involvement of a committed perpetual management agent, who need not be the owner of the bank site or bank credits. In exchange for management in perpetuity, credits granted for banks should be based on projected mature ecosystem values and functions. A mechanism for determining the present worth or equivalent present value needs to be established to allow the bank developer to realize the credits associated with perpetual care.

Because some banks may take decades to achieve their full levels of functions and values, MOAs must include management strategies to achieve these levels over time. Appropriate management strategies include ecosystem monitoring and milestones for ecosystem progress or recovery. In general, no active measures for bank preservation should be required because 
execution of these measures would be less certain over time. However, in cases where financial backing is provided for such measures, and where guaranteed by the MOA, active measures may be applied. In the event of unanticipated ecosystem decline or failure to meet milestones, some use of performance bonding may be appropriate to enhance recovery rates.

The effectiveness of individual banks can be determined on the basis of the achievement of the ecological, economic, and management goals identified in the MOA. Each MOA will be slightly different; however, the restoration, enhancement, or creation of a self-sustaining wetland of equal or greater value than the wetlands impacted may be considered ecologically effective. Economic effectiveness is the recovery of the investment capital and operating costs with a fair rate of return to the investor and operator. Effective management is the creation and execution of an MOA and a management plan that accelerate the permitting process, while maintaining the national policy of no overall net loss. Effectiveness of the banking concept can be defined as wide-spread regulatory, public, and private acceptance and use of multiple banks within a wide range of ecosystems.

\subsubsection{Regulatory}

The wetland mitigation bank is being considered across the country as a means of forwarding policy goals. The regulatory community is beginning to focus their efforts on the role mitigation banking will play. To help form the policies associated with mitigation banking and to smooth regulatory interaction, the following recommendations and conclusions require consideration.

Banks and banking transactions must be treated independently from the Section 404 permit sequencing in order to be viable. Treatment of banking as a last resort for wetland loss mitigation will increase the uncertainty for decision makers, including bank developers, increasing the risk that investment will not be compensated by potential returns. As a result, development of banks may be restrained. In addition, any banks that are implemented under these conditions may have a higher risk of undercapitalization and, ultimately, economic failure.

The current mistrust of banking as a policy is based on questions of equity of transactions and uncertainty over the permanence of the banked wetlands. Equity questions stem from the concept that all types of mitigation, including banking, are most effective when the compensation is in-kind. A change in this perception to recognize the potential value added from out-of-kind mitigation is necessary to make banking a successful policy. The question of permanence arises with most types of mitigation projects, not only with banking, and will be resolved only through the longevity of well-designed mitigation projects.

The most promising management structure for the oil and gas industry appears to be a cooperative structure involving both state and federal agencies. The Fina LaTerre bank provides an example of how the industry can maintain a degree of control, while incorporating the needs and values of the regulatory agencies. The Fina LaTerre structure is flexible in achieving the 
conflicting goals of the parties involved. By recognizing these goals and working cooperatively to manage the bank, the oil and gas industry can benefit from the economic, ecological, and regulatory opportunities that banking provides.

\subsection{Evaluation Criteria for Decision Making}

The decision to pursue wetland mitigation banking involves four fundamental levels of evaluation. These levels can be expressed by the following four questions:

1. Is wetland mitigation banking permissible?

2. Is wetland mitigation banking technically and ecologically feasible?

3. Is wetland mitigation banking economically feasible?

4. Is the banking concept being promoted by any special circumstances?

For any project or development within a geographic area, the answer to all four of these questions needs to be affirmative to justify proceeding with a wetland mitigation bank. None of these questions can be answered without further evaluation of the detailed components by the decision maker.

The outline shown in Table 5.1 presents decision components for evaluating the feasibility of wetland mitigation banking for a given project or development within a particular watershed. The common links to all of these considerations are (1) a knowledge of what the conditions are at a specific site and (2) a thorough understanding of the impacts being planned. Without prior planning of the wetland impacts, the process for deciding the feasibility of a wetland mitigation bank becomes unworkable, because the goal or measure of effectiveness is undefined. Each of the decision components is discussed in more detail in the following sections.

\subsubsection{Is Wetland Mitigation Banking Permissible?}

In evaluating the decision to be a participant in the ownership, management, or use of a mitigation bank, a company must first assess whether banking as a concept is accepted by the federal agencies that have jurisdiction over the geographic area to be served by the bank. If the federal agencies are favorable or open to banking, a positive decision can be made. If not, pursuit of a wetland mitigation bank is likely to be frustrating and fruitless. Similarly, the position of a state regulatory agency or a local county or parish agency can halt or enhance the development and use of a wetland mitigation bank. Under the current regulatory climate, the viability of a wetland 


\section{TABLE 5.1 Decision Components for Mitigation Banking}

1. Is wetland mitigation banking permissible?

1.1 Is the project within the jurisdiction of tederal agencies that allow mitigation banking?

1.2 Is the project in a state where mitigation banking is permitted?

1.3 is the project in a county/parish where wetland mitigation is permitted?

1.4 is off-site mitigation of impacts likely to be allowed?

2. Is wetland mitigation banking technically and ecologically feasible?

2.1 Are the wetlands to be impacted of a type that it is technically feasible to establish within a mitigation bank?

2.2 Are there sites within the watershed that can be developed into wetlands which can offset the anticipated wetland impacts of the project?

2.3 Are the available sites of sufficient size to offset the anticipated impacts?

2.4 Can the bank be developed in sufficient time to establish credits for the project?

3. Is wetland mitigation banking economically feasible?

3.1 Do the off-site mitigation ratios make banking cost-effective?

3.2 Are the size, number, and temporal distribution of the impacts large enough to achieve an economy of scale by using a mitigation bank?

3.3 Have historic wetland mitigation costs in the area been high?

3.4 Have historic wetland mitigation actions taken long times to permit?

3.5 Will regulatory agencies reduce ratios for mitigation with established credits in a mitigation bank?

3.6 Is the budget able to cover costs early in the project development to develop a mitigation bank?

3.7 Are there opportunities to sell excess credits for other developments in the area to offset or reimburse project costs?

3.8 Will the costs of banking, from site selection through long-term maintenance, be less than the cost of mitigating the planned impacts by other off-site methods?

4. Is the banking concept being promoted by any special circumstances?

4. 1 Is there a third party (local agency, conservation or environmental organization) with a special interest in protecting or enhancing wetlands in the area?

4.2 Are there sites that are natural extensions of existing protected wetland or related reserves?

4.3 Are there areas with threatened or endangered species or unique habitats that represent opportunities to develop a coincident wetland mitigation bank? 
mitigation bank is closely tied to the ability to mitigate wetland impacts off-site. If the regulators are not allowing off-site mitigation, a wetland mitigation bank is not viable. If all the involved regulatory parties are open to mitigation banking and to off-site mitigation of wetland impacts, a wetland mitigation bank can be permitted, and a participant may move on to evaluate whether the bank is ecologically and technically feasible.

\subsubsection{Is Wotland Mitigation Banking Tochnically and Ecologically Foaslble?}

The feasibility of wetland mitigation banking may lie in the types of impacts to be mitigated. If a developer is impacting bottomland hardwoods that require replacement in-kind, a wetland mitigation bank will be hard-pressed to mitigate these impacts unless a preserved bottomland hardwood area is part of the bank. The creation of such an ecosystem requires long lead times, typically beyond the scope of mitigation banking. Other wetland types may be considered critical on the basis of their function within a basin or watershed and cannot be technically replaced in another location. Conversely, a wetland mitigation bank may be placed in a strategic location to enhance a needed function, such as stormwater storage within a watershed, and thereby be highly beneficial to the basin management. The sites need to have adequate initial characteristics in the major delineation criteria of soils, hydrology, and vegetation to allow successful restoration or creation of a sustainable wetland. To be technically and ecologically feasible, a bank or bank system should be of adequate size to offset the anticipated impacts, with credits equal to or greater than the known or anticipated impacts. If the mitigation area can only accommodate the known project impacts, the area is a compensatory mitigation project and also a bank. The timing of banking requires careful consideration. A bank should be established with sufficient lead time to develop value and credits in advance of the impacts. Participation in a banking project requires foresight to permit a developer to take advantage of bank credits. If a bank can be created that ecologically addresses the anticipated impacts, has sufficient size to be a bank, and has sufficient time to develop credits, the bank is feasible, and the economics of pursuing a bank can be evaluated.

\subsubsection{Is Wotland Mitigation Banking Economically Feasible?}

The question of banking economics is a complex one that is specific to each bank. The economic viability of a wetland mitigation banking project is tied to the historic costs of other mitigation projects in the same area and the associated hidden costs of lengthy permit proceedings. Jurisdictions where mitigation ratios have been high and permit processing lengthy hold great potential for economic benefit. Banking can reduce the uncertainty that causes the high ratios and permitting difficulties. The economy of gathering small distributed impacts and mitigation projects into a bank can reduce the overall cost by reducing multiple mobilizations and contacts for mitigation. The banking concept also can address the issue of a developer being forced to procure mitigation sites on short notice, which can lead to exorbitant prices for property. A bank participant needs to determine whether the anticipated impacts warrant creation of an excess of credits in a bank to offset future unanticipated and planned impacts. A bank participant also needs to assess whether the regulatory agencies will reduce the ratios associated with banking or the 
trade-off values, when established, banked credits are used instead of new mitigation projects. The cash flow of a banking project must also be evaluated. Banking requires an outlay of capital at the outset of the project that cannot be recouped until the impacts occur. The value of streamlining the subsequent permitting and construction delay costs $\mathrm{m} \iota$ be weighed against the initial capital outlay and the routine management and maintenance costs associated with a bank. Bank planning can also assess the ability to sell credits to parties beside the owner. These credits can be sold at a profit to more quickly offset the cost of bank establishment. The future value of these credits needs to be evaluated in the cost benefit of any banking venture. Finally, the issue of long-term maintenance of the bank needs to be assessed. The bank is established to provide the environment with a self-sustaining wetland. However, there will be maintenance and monitoring costs associated with creating such a wetland and proving that it is functioning properly. These costs need to be evaluated in comparison with such other alternatives as off-site compensatory mitigation. The economics of each banking project will be unique. Consequently, each bank participant needs to assess how the initial investment is made, what the source of funds is, how the accounting for cost of credits will be assessed, and how for-profit sales may aid in the economic evaluation of a bank.

\subsubsection{Is the Banking Concept Being Promoted by Any Special Circumstances?}

The possibility often exists to align a banking project with the special interest of a resource agency or an environmental group. On occasion, state fish and game agencies and proactive environmental groups (such as the Nature Conservancy) are seeking to preserve or upgrade particular wetland parcels within a watershed. A bank participant may receive additional support from these groups in forwarding the concept of banking with regard to these areas. In many instances, areas needing protection from development are adjacent to existing natural resources. If such areas can be identified along with an interested resource group, the ability to create a bank is greatly enhanced and may be aided by the participation of a resource agency. Another consideration in identifying a bank site with high potential is the presence of threatened and endangered species or a unique habitat. These habitats are usually already protected, but they are of ten in need of a buffer zone to prevent degradation resulting from edge effects. Such a bufferzone mitigation bank may be perceived in a highly favorable light by local resource agencies and regulators. If these types of conditions exist, they have the ability to override the question of permissibility, due to their desirability in the local community.

\subsubsection{Decision Evaluation Summary}

Overall, in assessing whether a wetland mitigation bank is feasible for a particular area or project plan, the questions of permissibility, feasibility, economics, and special considerations must be addressed. Each wetland mitigation banking situation will be unique, but the considerations and decision factors presented in this report must be addressed. The most critical aspect of any banking project will be how the bank economics work with the economic flow of the participant. The value of participation in a wetland bank will be a function of how the cost and benefits are accounted for within the systems of the participants. 


\subsection{Recommendations for Future Work}

The oil and gas industry has a wide variety of needs, ranging from oil- and gas-field development through cross-country pipelines to distribution systems. In order to make a preliminary assessment of those needs, a DOE study has identified oil and gas production areas, oil and gas reserves, import facilities, refineries, and gas wells. These resources are in a digital format that may be loaded as a data layer for future analysis of the potential impacts to wetlands. Other sources for identifying the needs of the oil and gas industry are the annual reports identifying future expansion of the facilities listed above or the transmission systems for oil and gas. These expansions will have highly specific areal or linear features that may have associated wetland mitigation needs.

Ecological data have been gathered, and the appropriate information may be incorporated into a Geographic Information System (GIS) database. Currently available information includes data concerning the percent of hydric soils within each major land resource area. Other data that could be added include other pertinent soils data (e.g., percent organic matter, $\mathrm{pH}$, permeability), USFWS wetland delineation, as well as various types of remotely sensed data (such as AVHRR, Landsat TM, and SPOT) to interpret vegetation type, land-use characteristics, etc. An attempt will be made to gather information on ecological regions (and possibly subregions) for various portions of the country.

The data available at this time regarding regulatory issues has been incorporated into a GIS database. The positions of various states on wetland mitigation banking have been put into digital form and will be modified as the positions change. States that have regulations governing wetland mitigation beyond Section 404 of the Clean Water Act have also been entered into the GIS database, as have the jurisdictions of the regions for the three major federal regulatory agencies. Using the regulatory database within the GIS, the appropriate regions of federal jurisdiction and any state regulations or state concerns on wetland mitigation can be identified for a region of interest. As the need arises, additional information can be tied to these data layers, such as the positions of different federal regions on banking, special state considerations, and even county or parish jurisdiction. 


\section{References}

Anderson, R., and M. Rockel, 1990, Economic Valuation of Wetlands, draft working paper, American Petroleum Institute, Policy Analysis Department, Washington, D.C.

Brealey, R., and S. Myers, 1984, Principles of Corporate Finance, 2nd ed., McGraw-Hill Co., New York, N.Y.

Britsch, L.D., and E.B. Kemp, 1990, Land Loss Rates: Mississippi River Deltaic Plain, GL-90-2, prepared by U.S. Army Corps of Engineers, New Orleans, La.

California Department of Fish and Game, 1991, Guidelines for the Establishment of Wetland Mitigation Banks, Environmental Services Division, Sacramento, Calif.

Cowardin, L.M., V. Carter, F.C. Golet, and E.T. LaRoe, 1979, Classification of Wetlands and Deepwater Habitats of the United States, performed for Office of Biological Services, FWS/OBS79/31, U.S. Government Printing Office, Waslington, D.C.

DuPage County Stormwater Management Committee, 1992, Appendix E, Technical Guidance for the DuPage Countywide Stormwater and Flood Plain Ordinance, April 1992, prepared with DuPage County Stormwater Management Division and CH2M Hill, Wheaton, Ill.

Eggers, S.D., 1992, Compensatory Wetland Mitigation: Some Problems and Suggestions for Corrective Measures, U.S. Army Corps of Engineers, St. Paul District, St. Paul, Minn.

Environmental Law Institute, 1993, Wetland Mitigation Banking, Washington, D.C.

Federal Interagency Committee for Wetland Delineation, 1989, Federal Manual for Identifying and Delineating Jurisdictional Wetlands, Cooperative Technical Publication, U.S. Army Corps of Engineers, U.S. Environmental Protection Agency, U.S. Fish and Wildlife Service, and U.S. Department of Agriculture Soil Conservation Service, Washington, D.C.

FICWD: see Federal Interagency Committee for Wetland Delineation

Freeman, A.M., 1979, The Benefits of Environmental Improvement: Theory and Practices. Resources for the Future, Johns Hopkins University Press, Baltimore, Md.

Gosselink, J.G., and E. Maltby, 1990, "Wetland Losses and Gains," in Wetlands: A Threatened Landscape, M. Williams (editor), The Institute of British Geographers Special Publication Series 25, The Alden Press Ltd., Osney Mead, Oxford, England 
Hammer, D.A., 1992, Creating Freshwater Wetlands, Lewis Publishers, Inc., Chelsea, Mich.

Krutilla, J.V., and A.C. Fisher, 1985, The Economics of Natural Environments: Studies in the Valuation of Commodity and Amenity Resources, Resources for the Future, Washington, D.C.

Lewis III, R., 1990, "Wetlands Restoration/Creation/Enhancement Terminology: Suggestions for Standardization," in Wetland Creation and Restoration - the Status of the Science, J. Kusler and M. Kentula (editors), Island Press, Washington, D.C.

Minnesota Department of Transportation, 1987, Guidelines for Implementation of Wetland Habitat Mitigation Banking, Technical Memorandum No. 87-28-ENV-2, Technical Services Division, St. Paul, Minn., June 18, 1987.

Mitsch, W.J., and J.G. Gosselink, 1986, Wetlands, Van Nostrand Reinhold Company, Inc., New York, N.Y.

Riddle, E.P., and M.F. Denniger, 1985, "Coastal Wetlands Mitigation Banks: The California State Coastal Conservancy Experience," Proceedings: National Wetlands Assessment Symposium. Association of State Wetland Managers, Inc., held in Portland, Maine, June 17-20, 1985. pp. 260-264.

Reppert, R., 1992, Wetlands Mitigation Banking Concepts, U.S. Army Corps of Engineers, Institute of Water Research Support Center, Fort Belvoir, Va.

Shabman, L., D. King, and P. Scodari, 1993, Making Wetlands Mitigation Work: The Credit Market Alternative, Executive Summary, Department of Agricultural and Applied Economics, Virginia Polytechnic Institute and State University, Blacksburg, Va.

Short, C., 1988, Mitigation Banking, Biological Report 88(41), National Ecology Research Center, prepared for U.S. Fish and Wildlife Service, Washington, D.C.

Turner, R.E., and D.R. Cahoon (editors), 1988, Causes of Wetland Loss in the Coastal Central Gulf of Mexico, OCS Study/MMS 87-120, Minerals Management Service, New Orleans, La.

U.S. Army Corps of Engineers, 1987, Corps of Engineers Wetlands Delineation Manual, Technical Report Y-87-1, Waterways Experiment Station, Vicksburg, Miss.

U.S. Environmental Protection Agency and Department of Energy, 1993, Memorandum of Understanding to the Field Offices, Aug. 23. 
World Wildlife Fund, 1990, Statewide Wetlands Strategies: A Guide to Protecting and Managing the Resource, Island Press, Washington, D.C.

White House Office on Environmental Policy, 1993, Protecting America's Wetlands: A Fair, Flexible, and Effective Approach, Washington, D.C. 
Appendix A:

Wetland Mitigation Banking Definitions and Terms 


\section{Appendlx A:}

\section{Wetland Mitigation Banking Definltions and Terms}

\section{A.1 Bank-Specific Definitions}

Adverse Wetland Impact: Any diminishment of wetland acreage or functional value.

A priori Mitigation: Restoration, creation, or enhancement of some combination of ecological functions and values to offset future losses of those values caused by adverse impacts to an existing wetland(s) and resulting in no net loss of wetland areas. Preservation of existing wetlands may be included under special circumstances.

Artificial Wetland: Created wetland requiring constant or continued application of water or maintenance (e.g., plantings, dredging, removal of exotic species) to provide continued wetland values. (adapted from Lewis 1990)

Bank Account: An account representing accrued wetland debits and credits, arrived at through the wetland mitigation banking process for a designated area (e.g., hydrologic basin, ecoregion, county). One bank account is established and maintained for each operational wetland mitigation bank. (adapted from Minnesota Department of Transportation 1987)

Bank Developer: Legal entity empowered to acquire land and create or restore and maintain wetland habitat upon that land. The bank developer may operate and maintain such land as a qualified wetland mitigation bank pursuant to the conditions of an operations agreement with appropriate regulatory agencies or may embloy an agent(s) to actually operate the mitigation bank provided the agent(s) has been approved by the regulatory agencies. (adapted from California Department of Fish and Game 1991)

Bank Managers/Operators: Group of public agency officials (e.g., local, county, state, federal) or private organization(s) (e.g., corporations, developers, industries) representing the interests, goals, and objectives of the wetland mitigation bank.

Best Management Practices: Conservation practices or systems of management actions that (1) control soil loss and reduce water quality degradation caused by nutrients, animal waste, toxins, and sediment, and (2) minimize adverse impacts to the surface water, groundwater flow, and circulation pattern, and to the chemical, physical, and biological characteristics of wetlands.

Buffer Zone: An area or zone of land (often an unregulated, upland area) located adjacent to a wetland mitigation bank for the purpose of protecting the wetland habitat, wildlife, and other resource values within the bank from potential adverse impacts of current or future activities 
occurring outside the buffer zone. The physical character of a buffer zone may vary. Buffer zones may be composed of open water (to limit pedestrian access) and include fences or walls (to reduce human and domestic animal intrusion), as well as unbroken screens of vegetation or berms (to reduce noise and visual intrusion). Buffer zones should be of sufficient width and of such design to preclude disturbance-associated impacts to the most sensitive species inhabiting the mitigation bank site. (adapted from California Department of Fish and Game 1991) See also Nonwetland, Transition Zone, Upland, Wetland Boundary, and Wetland Limits.

Compensation: Replacement of a lost wetland function with a function of equal or greater value.

Concurrent (Compensatory) Mitigation: A form of on-site or off-site mitigation occurring at the same time the impacts are incurred. It may include restoration, replacement, creation, substitution, enhancement, protection, or some combination of ecological functions and values to offset anticipated or actual losses of values caused by adverse impacts to an existing wetland(s) and resulting in no net loss of wetland areas.

Cooperating Agency: Any federal, state, county, or local regulatory agency participating in the development, operation, regulation, maintenance, or monitoring of a wetland mitigation bank.

Created Wetland: An area (persistent upland or shallow-water area) converted into a wetland through human activities. This definition presumes the site has not been a wetland within recent times (100-200 years) and, therefore, is not considered wetland restoration. (adapted from Lewis 1990)

Credit: Positive habitat unit value, acreage, or other value gained by wetland creation, restoration, enhancement, or preservation. Each habitat unit value is assigned by the designated bank managing agency in coordination with other appropriate resource and regulatory agencies. See also Currency.

Credit Area: Mitigation site that has been accepted into a wetland mitigation bank by bank managers. The site can consist of a wetland that is or will be created, restored, or enhanced through habitat management (or preserved from imminent destruction) and provides habitat unit credits to the wetland mitigation bank account. The area may be subdivided into numerous smaller distinct credit areas for exchange. The minimum credit area is a function of the nature of impacts, the type of mitigation, and the size of the impacts.

Credit Balance: Unused wetland habitat units or acreage. It is the remaining, unused balance left in a particular user's account or the total remaining amount of unused acreage or habitat units available at the wetland mitigation bank.

Currency: The commodity being credited and debited through the mitigation banking process. The commodity basis of the currency will typically be a habitat unit value, some measure of 
wetland area (i.e., acreage), or other agreed-upon value. See also Credit, Debit, and Exchange Rate.

Debit: A habitat unit value or acreage measurement owed by a wetland developer to society based on established state/federal regulatory criteria. The debit arises from the alteration of an existing wetland that reduces, alters, or eliminates its ecological values and functions. The debit is made against credits established by the developer in a mitigation bank.

Debit Area: An unavoidable wetland-impact area that has been accepted by the wetland bank managers as a candidate for mitigation banking. Debit areas are wetland habitat that would be unavoidably impacted through project construction, thereby requiring compensation for its lost habitat value by withdrawal of habitat units (wetland credits) from the wetland mitigation bank account. (adapted from Minnesota Department of Transportation 1987)

Debit Balance: Results when all of the mitigation required for a given project cannot be accomplished economically or biologically. A debit balance requires mitigation of the balance outside of the bank. (adapted from Minnesota Department of Transportation 1987)

Degraded Wetland: A wetland altered by man through impairment of some physical or chemical property that results in a reduction of habitat value or reduction of biological or physical functions (e.g., flood storage). (adapted from Lewis 1990)

Developer: See Project Proponent.

Disturbed Wetland: A wetland directly or indirectly altered from a natural condition, yet retaining some natural characteristics, which can include natural perturbations. (Lewis 1990)

Effectiveness: Attainment of established goals and objectives, preferably measurable as quantitative values that are determined prior to the establishment of a wetland mitigation bank. Inherent in the concept of effectiveness is the incorporation of a properly funded management plan (development, maintenance, and monitoring throughout the life of the bank) for the mitigation bank site.

Enhanced Wetland: Existing wetland whose value of one or more ecological functions has been increased by human activities. It should be recognized that the increased value of one ecological function could be accompanied by the decline of other functions and values. Enhanced wetlands may have added value in a mitigation bank beyond preservation. (adapted from Lewis 1990)

Environmental Performance Bond: A financial tool that a developer is required to provide to preserve the ability to perform a corrective action and to provide an incentive for proper mitigation activities. 
Exchange Rate: The price (rate) at which debits caused by wetland development are traded for credits generated by mitigation banking. The exchange rate for the currency in the mitigation banking process can be influenced by (1) the total number of jurisdictional acres impacted, (2) the geographic location of the impacted site and mitigation bank, (3) the condition of the particular jurisdictional wetland(s), and (4) the functions performed by the impacted wetland(s). Differing mitigation actions, unique characteristics of the impacted wetland, and the type of development also may influence the exchange rates for currency. Pecuniary and ecological considerations involving regulatory and maintenance costs and risk elements present in the development also will affect the exchange rate for mitigation banking currency.

Function(s): What a wetland does (e.g., physical, biological or chemical processes), regardless of the interpretation of its relative worth. Wetland functions include, but are not limited to, floodwater storage, floodwater conveyance, groundwater recharge and discharge, erosion control, wave attenuation, water-quality protection, scenic and aesthetic use, food-chain support, fisheries, wetland-plant habitat, aquatic habitat, and wildlife habitat areas. See also Value(s).

Functional Equivalency: The ability of a restored, created, or enhanced wetland to perform ecosystem functions (e.g., floodwater storage or pollutant detoxification) that are indistinguishable in effects from corresponding functions by other natural ecosystems. (adapted from Lewis 1990)

Habitat Evaluation Procedure (HEP): Procedure used to determine the wildlife habitat value of wetland debit and credit areas in terms of habitat units. It can be used as a generic term or in specific reference to the U.S. Fish and Wildlife Service approach. (U.S. Fish and Wildlife Service 1980)

Habitat Units: The currency used to quantify the value of wetland debit areas as well as credit areas. Habitat units equal habitat value (quality rated on a scale of 0 to 100) multiplied by habitat quantity (acreage). (U.S. Fish and Wildlife Service 1980)

Habitat Value: Suitability (or value) of an area to support a given species or group of species as determined through the habitat evaluation procedure (HEP). (adapted from Lewis 1990)

In-kind Replacement: Substitute resources to replace the functional values of the resources lost, where such substitute resources are physically and biologically similar to those that were displaced. (Lewis 1990)

In lieu fee Mitigation: A planning approach for compensating unavoidable loss of wetlands or wetland functions, resulting from development actions where mitigation cannot be achieved at the site of impact. Such a program permits unavoidable wetland losses to be credited by the developer through a cash allotment to a central fund earmarked for the development of an off-site wetland. The compensating wetland will be developed when the value of the fund is sufficient to construct such a wetland. By this mitigation process, wetland debits (losses) exist for a given period of time before development of the wetland occurs and wetland losses are compensated. In an in lieu fee 
mitigation, the wetland may or may not exist prior to the credits being used. See also Wetlands Trust Fund.

Joint Project: A restoration, creati ,.l, or enhancement project undertaken jointly by several developers (and sometimes government agencies and nonprofit organizations) to compensate for specific proposed project impacts. With a joint project, no bank of future credits is established. (Kusler 1992)

Maintenance: Activities required to assure the continuation of wetland functions or the accomplishment of project goals after a restoration, creation, or enhancement project has been technically completed. Such activities include, but are not limited to, water-level manipulations, erosion control, and control of nonnative plant species. (adapted from Maine Department of Environmental Protection 1990)

Marginal Wetlands: Wetland areas that have been altered by human activities or natural processes to such an extent that the site has extremely limited functions as a wetland.

Mitigation: All actions taken to offset potential adverse environmental impacts, including avoiding, minimizing, rectifying, reducing, or compensating an impact (ecological values lost dut to human activities). See also Sequencing and Wetland Mitigation.

Mitigation (1991 Regulatory Definition): The Council on Environmental Quality, under the auspices of the National Environmental Policy Act, defined mitigation as (a) avoiding the impact altogether by not taking a certain action or parts of an action; (b) minimizing impacts by limiting the degree or magnitude of the action and its implementation; (c) rectifying the impact by repairing, rehabilitating, or restoring the affected environment; (d) reducing or eliminating the impact over time by preservation and maintenance operations during the life of the action; and (e) compensating for the impact by replacing or providing substitute resources or environments (40 CFR Part 1508.20[a.e]). See also Sequencing and Wetland Mitigation.

Mitigation Banking (Current Regulatory Definition): The 1981 Mitigation Policy (46 CFR 7644) and Interim Guidance on Mitigation Banking (U.S. Fish and Wildlife Service 1983) defines mitigation banking as habitat protection or improvement actions taken expressly for the purpose of compensating for unavoidable, necessary losses from specific future development actions.

Mitigation Banking (Project Definition): A program or approach that permits unavoidable wetland losses that cannot be adequately mitigated at the site to be offset with credits earned previously through mitigation actions undertaken off-site. Mitigation actions for banking include restoration, creation, and enhancement of wetlands and, in special circumstances, may include the preservation of wetland and adjacent upland areas. Compensatory mitigation is accomplished for more than one project, in advance of applications for permits, at either a single, large wetland site or a series of hydrologically connected wetland sites. The development of a mitigation bank may 
include the restoration or enhancement of existing degraded wetlands or the creation of new wetlands from upland areas. Preservation of existing wetlands should be recognized only in special circumstances. Preservation may include protection of uplands that are associated with the wetland system. To be qualified, such banks must have received the review and approval of all appropriate regulatory agencies.

Mitigation Ratio: The ratio of acreage or some standardized form of habitat unit at which wetland losses shall be replaced by creating, restoring, or enhancing wetlands (e.g., 1:1 for emergent wetlands, $2: 1$ for forested wetlands, 3:1 for critical wetlands of special concern). See also Exchange Rate.

Monitoring: Periodic evaluations of a mitigation site to determine the level of effectiveness or failure in attaining goals and objectives. The duration of the monitoring period is dependent upon the goals and objectives set forth in the mitigation project. (adapted from Lewis 1990)

Nonwetlands: Those upland and lowland areas that are not deepwater aquatic habitats, wetlands, or other special aquatic sites. They are seldom or never inundated, or if frequently inundated, they have saturated soils for only brief periods during the growing season. If vegetated, they normally support a prevalence of vegetation typically adapted for life only in aerobic soil conditions. (U.S. Army Corps of Engineers 1987). See also Buffer Zone, Transition Zone, Upland, Wetland Boundary, and Wetland Limits.

Off-Site Mitigation: A method of mitigation whereby the debt balance is eliminated by the creation, restoration, or enhancement of a wetland not located within or adjacent to the development site. Through this mitigation method, the debits created by the development are directly and completely offset by credits created by the off-site mitigation, which typically occurs concurrently or after development has iaken place.

On-Site Mitigation: A method of mitigation whereby the debt balance is eliminated by the creation, restoration, or enhancement of a wetland located within or adjacent to the development site. Through this mitigation method, the debits created by the development are directly and completely offset by credits created by the on-site mitigation, which typically occurs concurrently or after development has taken place.

Out-of-Kind Replacement: Substitution of resources to replace the functional values of the wetland resources lost, where such substitute resources are physically or biologically different from those displaced. (adapted from Lewis 1990)

Preservation: Maintenance of an area so that it remains in a natural or undeveloped condition. Preservation measures include, but are not limited to, fee-simple purchase, conservation easements, and land trusts. 
Project Proponent: Public or private entity acting on its proprietary or managerial capacity in attempting to implement a project. (adapted from California Department of Fish and Game 1991)

Reclaimed Wetland: Same definition as restored wetland, but this term is often used in other parts of the world to refer to wetland destruction as a result of filling or draining activities. (Lewis 1990) See also Restored Wetlands.

Regulatory Risk: The risks of (1) extensive resources and time being devoted to the task of applying for a permit and receiving approval of mitigation activities and (2) the possibility of excessive delays in receiving the necessary approvals from state and federal permitting agencies. Regulatory risk is often associated with economic risk and ecological risk.

Restored Wetland: Reestablished wetland on a site that once supported a wetland or a marginal wetland rehabilitated to a previously existing condition (natural or altered) by some human action. It is not necessary to have complete knowledge of preexisting wetland conditions; rather, the goal is the reestablishment of the same wetland type.

Sequencing: The standard ranking approach to mitigation (as defined by the USEPA 1989) of (1) avoidance, (2) minimization, (3) edification or redirection on-site, and (4) conpensation offsite. An additional preference is for in-kind over out-of-kind mitigation. ite also In-Kind Replacement, Off-Site Mitigation, On-Site Mitigation, and Out-of-Kind Replacement, Mitigation (1992 Regulatory Definition).

Success: See Effectiveness.

Transition Zone: Area in which a change from a wetland to nonwetland environment occurs (determined on the basis of hydrology, vegetation, and soils). The transition zone may be either narrow or broad, with the upper extent of the transition zone becoming either uplands or deepwater habitat. (adapted from USACOE 1987). Such areas are often used as buffer zones for the designated wetland area. (adapted from Lewis 1990) See also Buffer Zone, Deepwater Habitats, Nonwetland, Upland, Wetland Boundary, and Wetland Limits.

Unavoidable Wetland Loss: Impact to a wetland occurring because of a lack of other feasible project alternatives.

Upland: An area that does not qualify as a wetland because the associated hydrologic regime is not sufficient to elicit development of wetland vegetation, soils, and/or hydrologic characteristics. Such areas occurring within floodplains are more appropriately termed nonwetlands. See also Buffer Zone, Nonwetland, Transition Zone, Wetland Boundary, and Wetland Limits.

Value(s): The importance of a wetland with respect to the function(s) it provides. Wetland values are an interpretation of the relative economic worth of wetland functions and can be either 
positive or negative. Values are determined by evaluating biotic and abiotic factors and their dynamic interactions, as opposed to static measurements only. See also Function(s).

Wetland Evaluation Technique (WET): A comprehensive habitat assessment method developed by three federal agencies that is commonly used by mitigation banks. The WET results in qualitative ratings for a broad array of wetland functions. (CH2M Hill 1993)

Wetland (Project Definition): An area inundated or saturated by surface water or groundwater (hydrology being the dominant factor) at a frequency and duration sufficient to support, and that under normal circumstances does support, a prevalence of vegetation (hydrophytic) typically adapted for life in saturated soil (hydric) conditions. Wetlands generally include swamps, marshes, bogs, prairie potholes, fens, wet meadows, and similar areas. Wetlands are often transitional zones between open water and dry land. (Lewis 1990)

Wetland Mitigation Bank: See Mitigation Banking.

Wetlands (Regulatory Definitions): Federal regulatory definitions vary by agency and are as follows:

- U.S. Environmental Protection Agency and U.S. Army Corps of Engineers - Those areas that are inundated or saturated by surface or groundwater at a frequency and duration sufficient to support, and that under normal circumstances do support, a prevalence of vegetation typicaliy adapted for life in saturated soil conditions. Wetlands generally include swamps, marshes, bogs, and similar areas. This definition used in the 1987 Corps of Engineers Wetlands Delineation Manual, remains the current, official federal regulatory definition. (40 CFR 230.3, 1980 and 33 CFR 328.3, 1982)

- U.S. Soil Conservation Service - Wetlands are defined as areas that have a predominance of hydric soils and that are inundated or saturated by surface water or groundwater at a frequency and duration sufficient to support, and under normal circumstances do support, a prevalence of hydrophytic vegetation typically adapted for life in saturated soil conditions, except lands in Alaska identified as having a high potential for agricultural development and a predominance of permafrost soils. (National Food Security Act Manual 1983 referenced in Wetland Training Institute 1989)

- U.S. Fish and Wildlife Service - Wetlands are transitional lands between terrestrial and aquatic systems where the water table is usually at or near the surface or the land is covered by shallow water. For purposes of this classification, wetlands must have one or more of the following three attributes: (1) at least periodically, the land supports predominantly hydrophytes; (2) the substrate is predominantly undrained hydritic soil; and (3) the substrate is nonsoil and is saturated with water or covered by shallow water at some time during the growing season of each year. (Cowardin et al. 1979) 


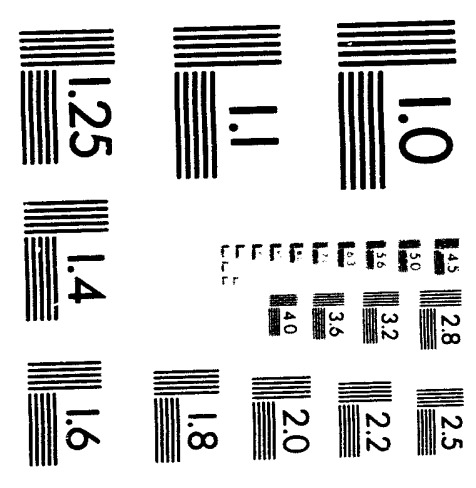



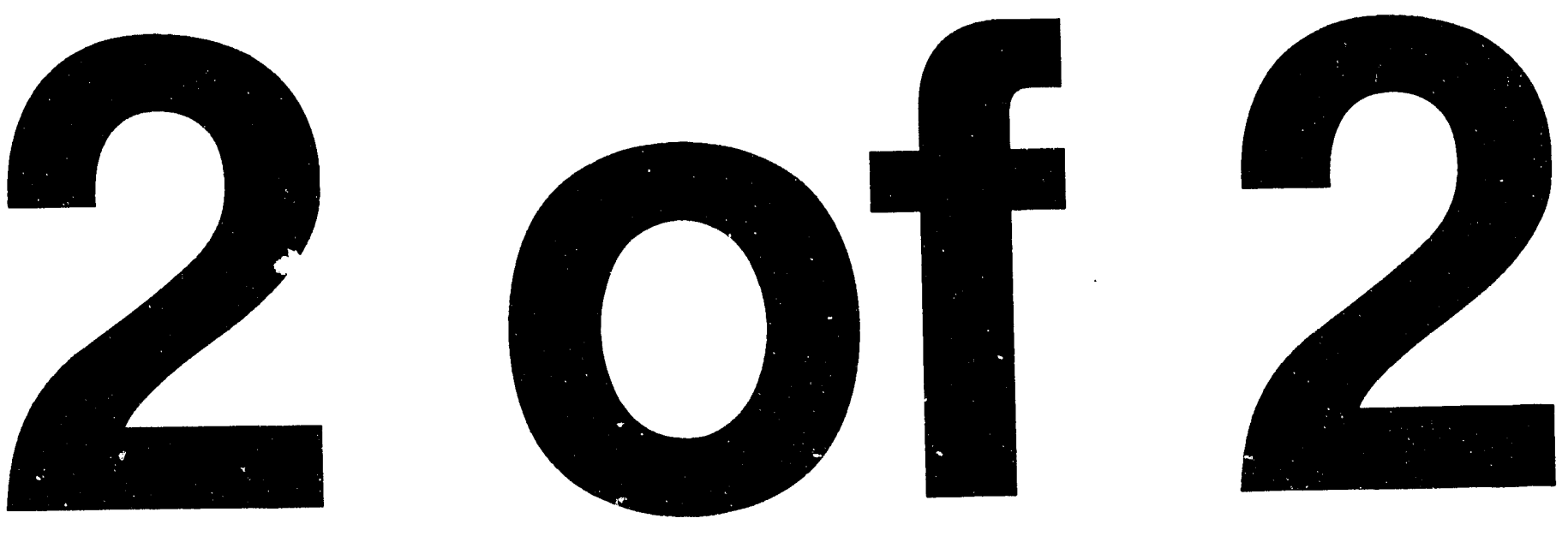
Wetland Boundary: A point on the ground at which a shift from wetland to nonwetland or aquatic habitat occurs. A boundary usually follows topographic contours and should be determined from (but not at) the high water mark, not the low water level. (adapted from Odum 1989 and USACOE 1987). See also Buffer Zone, Nonwetland, Transition Zone, Upland, and Wetland Limits.

Wetland Classification System: A method for grouping wetlands that refers to a complex set of wetlands and deepwater habitats which share the influence of similar hydrologic, geomorphologic, chemical, or biological factors. The basic classification system (with many subclassification schemes) consists of five major components: (1) marine, (2) estuarine, (3) riverine, (4) lacustrine, and (5) palustrine. (Cowardin et al. 1979)

Wetland Limits: The extent of a wetland can be defined by its deepwater and upland limits (Cowardin et al. 1979) and are described as follows:

- Deepwater - These are permanently flooded lands lying below the deepwater boundary of wetlands. Such areas are permanently inundated at a mean annual water depth of less than $6.6 \mathrm{ft}$ $(2 \mathrm{~m})$. Also, a permanently inundated area that is less than or equal to $6.6 \mathrm{ft}$ (or $2 \mathrm{~m}$ ) in depth that does not support rooted-emergent or woody plant species.

- Upland - The upland limits of wetlands are designated as (1) the boundary between land with predominantly hydrophytic cover and land with predominantly mesophytic or xerophytic cover; (2) the boundary between soil that is predominantly hydric and soil that is predominantly nonhydric; and (3) in the case of wetlands without vegetation or soil, the boundary between land that is flooded or saturated at some time during the growing season each year and land that is not. Wetland limits are often legally defined within each state. See also Buffer Zone, Nonwetlands, Transition Zone, Uplands, and Wetland Boundary.

Wetland Mitigation: Any activity taken to compensate man-made damage to wetlands. Mitigation activities can include, but are not limited to, the restoration, enhancement, or creation of wetlands. Mitigation practices allow development to occur in wetlands while ensuring that the destruction of wetlands will eventually be rectified through either $a$ priori or a posteriori efforts. Such practices are usually employed only after avoidance and minimization of wetland resource impacts have been achieved to the most practical extent. Wetlands that have functions and values diminished by human impacts can be restored through various mitigative management techniques. See also Mitigation.

Wetland Site: An identifiable property, tract, area, or region containing wetlands or a complex (aggregation) of physically or functionally related wetlands. A wetland site may contain a variety of wetland types, interspersed habitat of other types, and associated upland buffer areas. The boundary of the site should be specific and as geographically restricted as practical, as determined by application of sound acquisition principles. In other words, regardless of size, a wetland site should be treated in terms of a unit that would generally fit the acquisition goals, process, and needs of the user. (U.S. Fish and Wildlife Service 1989) 
Wetland Types: Classification on the basis of physical, botanical, and hydrological characteristics. A classification system described by Cowardin et al. (1979) can serve as the basis for determining types of wetlands within any given region. These wetland types include marshes, scrub-shrub, bogs, wet prairie/wet meadow, fens, prairie potholes, bottomland hardwoods, emergent wetlands, mangrove swamps, swamps, pocosins, vernal pools, peatland, reed swamp, slough, and playa.

Wetlands Trust Fund: A concept for wetland mitigation under which developers make cash contributions to a trust fund maintained by a local, state, or federal entity in order to cover the wetland impacts for which they are responsible. Accumulated monies are then used to provide replacement wetlands for mitigation purposes after the fact. See also In lieu fee Mitigation.

\section{A.2 Bibliography for Bank-Specific Definitions}

The bank-specific definitions were taken verbatim, derived, or adapted from some of the following sources:

Anderson, R., and M. Rockel, 1990, Economic Valuation of Wetlands, draft working paper, American Petroleum Institute, Policy Analysis Department, Washington D.C.

Broome, S., 1990, "Creation and Restoration of Tidal Wetlands of the Southeastern United States," in Wetland Creation and Restoration, the Status of the Science, J. Kusler and M. Kentula (editors), Island Press, Washington D.C.

Burke, D., et al., 1988, Protecting Nontidal Wetlands, Report No. 412/413, American Planning Association, Chicago, Ill.

California Department of Fish and Game, 1991, Gvidelines for the Establishment of Wetland Mitigation Banks, Environmental Services Division, Sacramento, Calif.

CH2M Hill, 1993, Draft Technical Memorandum No. 1, Literature Data Review: Ancillary Environmental Benefits of Reservoirs/Wetland Mitigation Banking, prepared for American Water Works Association, Portland, Ore.

Connecticut Department of Environmental Protection, no date, Wetlands Compensation, A Policy Proposal, Inland Water Resources Management Division in cooperation with the Commissioner's Task Force on Wetlands Compensation, Hartford, Conn.

Cowardin, L.M., et al., 1979, Classification of Wetlands and Deepwater Habitats of the United States, FWS/OBS-79/31, prepared for U.S. Fish and Wildlife Service, Office of Biological Services, U.S. Government Printing Office, Washington, D.C. 
Dunham, F., 1985, "Mitigation Banking: A State Perspective," in Proceedings: National Wetlands Assessment Symposium, sponsored by Association of Wetland Managers, Inc., held in Portland, Maine, June 17-20, 1985.

Federal Interagency Committee for Wetland Delineation, 1989, Federal Manual for Identifying and Delineating Jurisdictional Wetlands, Cooperative Technical Publication, U.S. Army Corps of Engineers, U.S. Environmental Protection Agency, U.S. Fish and Wildlife Service, and U.S. Department of Agriculture Soil Conservation Service, Washington D.C.

Jatnieks-Straumanis, S., and L. Foote, 1988, "Wetland Mitigation Banking -- How it Works in Minnesota," Rangelands 10(3):120-123.

Kusler, J., 1992, "Mitigation Banks and Joint Projects: A National Perspective on Issues," in Mitigation Banks and Joint Projects in the Context of Wetland Management Plans, National Wetlands Symposium, sponsored by Association of State Wetland Managers, held at Palm Beach Gardens, Florida, June 24-27, 1992.

Kusler, J., and M. Kentula (editors), 1990, Wetland Creation and Restoration, the Status of the Science, lsland Press, Washington D.C.

Krucyznski, W., 1990, "Options to be Considered in Preparation and Evaluation of Mitigation Plans," in Wetland Creation and Restoration, the Status of the Science, J. Kusler and M. Kentula (editors), Island Press, Washington D.C.

Lewis III, R., 1990, "Wetlands Restoration/Creation/Enhancement Terminology: Suggestions for Standardization," in Wetland Creation and Restoration, the Status of the Science, J. Kusler and M. Kentula (editors), Island Press, Washington D.C.

Maine Department of Environmental Protection, 1990, Natural Resources Protection Act, Wetland Protection Rules, Chapter 310, Bureau of Land Quality Control, Augusta, Me.

Maryland Department of Natural Resources, 1991, Nontidal Wetlands Protection Act and Regulations, Water Resources Administration, Annapolis, Md.

Minnesota Department of Transportation, 1987, Guidelines for Implementation of Wetland Habitat Mitigation Banking (WHMP), Technical Memorandum No. 87-28-ENV-2, Technical Services Division, St. Paul, Minn., June 18.

National Food Security Act Manual, 1988, as referenced in Field Guide for Wetland Delineation: Unified Federal Method, WTI 89-1, Wetland Training Institute, Inc., 1989. 
National Wildlife Federation, 1987, Status Report on Our Nation's Wetlands, Washington D.C., October.

Niedzialkowski, D., and J. Jaksch, 1989, "Wetlands Mitigation Banking As an Innovative Approach to Wetlands Regulation," in Freshwater Wetlands and Wildlife Symposium Proceedings, R. Sharitz and J. Gibbons (editors), Savannah River Ecology Laboratory, University of Georgia, conference held at Charleston, S.C., March 24-27, 1986.

Odum, E.P., 1989, "Wetland Values in Retrospect," in Freshwater Wetlands and Wildlife Symposium Proceedings, R. Sharitz and J. Gibbons (editors), Savannah River Ecology Laboratory, University of Georgia, conference held at Charleston, S.C., March 24-27 1986.

Riddle, E., 1986, "Mitigation Banks: Unmitigated Disaster or Sound Investment," in Proceedings: National Wetland Symposium, Mitigation of Impacts and Losses, Association of Wetland Managers, Inc., held at New Orleans, La., Oct. 8-10, 1986.

Riddle, E., and M. Denninger, 1985, "Coastal Wetlands Mitigation Banks: The California State Coastal Conservancy Experience," in Proceedings: National Wetlands Assessment Symposium, sponsored by Association of Wetland Managers, Inc., held in Portland, Maine., Junc 17-20, 1985.

Salvesen, D., 1990, Wetlands, Mitigating and Regulating Development Impacts, Urban Land Institute, Washington D.C.

Sharp, M.J., and P. Keddy, 1986, "A Quantitative Technique for Estimating the Boundaries of Wetlands from Vegetation Data," Environmental Management 10(1):107-112.

Short, C., 1988, Mitigation Banking, U.S. Fish and Wildlife Service Biological Report 88(41), prepared by National Ecology Research Center, Ft. Collins, Colo.

Solieu, D.M., J.D. Brown, and D.W. Fruge, 1985, "Mitigation Banking: a Mechanism for Compensating Unavoidable Fish and Wildlife Habitat Losses," Transactions of the North American Wildlife Natural Resources Conference 50:465-474, as referenced in Short, C., 1988, Mitigation Banking, U.S. Fish and Wildlife Service Biological Report 88(41), prepared by National Ecology Research Center, Ft. Collins, Colo.

State of Florida, 1992, Report and Recommendations of the Environmental Regulation Commission Mitigation Banking Task Force, Department of Environmental Regulation, Tallahassee, Fla.

State of Illinois, 1989, Interagency Wetland Policy Act of 1989, draft house bill, Springfield, Ill. 
State of Louisiana, 1990, Act 1040, Mitigation of Coastal Wetland Losses, R.S. 49:214.41, approved July 26, 1990, Baton Rouge, La.

State of Maryland, 1991, Nontidal Wetlands Protection Act, Natural Resources Article, Sec. 8-1201 et seq., effective May 13, 1991, Annotated Code of Maryland, Annapolis, Md.

State of Wyoming, 1991, House Bill No. 0048A, Wetlands Act, not adopted, Cheyenne, Wyo.

Tennessee Department of Transportation, no date, Wetland Mitigation Banking: Plan and Memorandum of Agreement, preliminary draft, Environmental Planning Office, Nashville, Tenn.

Tettemer, J., 1986, "Mitigation Banking: Our Best Chance for Long-Term Wetlands Preservation and Management," in Proceedings: National Wetland Symposium, Mitigation of Impacts and Losses, Association of Wetland Managers, Inc., held at New Orleans, La., October 8-10.

U.S. Army Corps of Engineers, 1987, Corps of Engineers Wetlands Delineation Manual, Technical Report Y-87-1, Waterways Experiment Station, Vicksburg, Miss.

U.S. Environmental Protection Agency, 1991, Proposed Revisions to the Federal Manual for Delineating Wetlands, Office of Wetlands, Oceans, and Watersheds, Washington D.C.

U.S. Environmental Protection Agency, 1989, Highlights of Section 404, Federal Regulatory Program to Protect Waters of the United States, Office of Wetlands Protection, Washington D.C.

U.S. Environmental Protection Agency, 1988, Protecting our Nation's Wetlands and Your Pocketbook, EPA Fact Sheet, Region 5, Chicago, Ill.

U.S. Fish and Wildlife Service, 1983, Interim Guidance on Mitigation Banking, Ecology Service Instructional Memo 80, Washington, D.C.

U.S. Fish and Wildlife Service, 1989, National Wetlands Priority Conservation Plan, Washington, D.C.

U.S. Fish and Wildlife Service, 1980, Habitat Evaluation Procedures (HEP) Manual, Washington, D.C.

Wetland Training Institute, Inc., 1989, Field Guide for Wetland Delineation: Unified Federal Method, WTI 89-1.

Wisconsin Department of Natural Resources, 1990, Compensatory Mitigation Policy for Unavoidable Wetland Losses Resulting from State Transportation Activities, an amendment to the 
Interagency Cooperative Agreement between the Wisconsin Department of Natural Resources and the Wisconsin Department of Transportation, Madison, Wis.

Wisconsin Department of Transportation, 1989, Patrick Lake Wetland Mitigation Bank for Transportation District 1, Wisconsin Department of Transportation Highway Projects, Division of Highways and Transportation Services, Madison, Wis.

\section{A.3 General Wetland Definitions}

Aerobic: Pertaining to life in or conditions requiring free oxygen. (Steen 1971)

Anaerobic: A condition in which molecular oxygen is absent (or effectively so) from the environment. (adapted from Alonso and Gorsira 1992)

Adaptive Vegetation: Plant species that are not native but which provide value similar to native species and grow successfully within the wetland environment.

Agricultural Use: Use of a wetland as an agricultural basin for the commercial harvesting of rice, cranberries, fish, crayfish, etc.

Areal Cover: A measure of dominance that defines the degree to which aboveground portions of plants (not limited to those rooted in a sample plot) cover the ground surface. It is possible for the total areal cover in a community to exceed $100 \%$ because (1) many plant communities consist of two or more vegetative layers (overstory, understory, ground cover, undergrowth); (2) areal cover is estimated by vegetative layer; and (3) foliage within a single layer may overlap. (Lewis 1990)

Basal Area: The cross-sectional area of a tree trunk measured in square inches, square centimeters, etc. Basal area is normally measured at $4.5 \mathrm{ft}(1.4 \mathrm{~m}$.) above ground level (or just above the buttress if the buttress exceeds that height) and is used as a measure of dominance. (Lewis 1990)

Baseline Study: An inventory of a natural community or environment that may serve as a model for planning or for establishing goals for effectiveness criteria. A baseline study can be used to describe preimpact conditions. (Lewis 1990)

Bench Mark: A fixed, more or less permanent, ground reference point or object, for which the elevation and horizontal locations are known; commonly used in geological surveying. (Lewis 1990)

Biogeographic Region: An area delineated by its biological and geographic characteristics (both past and present). It is often based upon spatial patterns or distributions of major common or 
dominant plant or animal groups and various physical factors. (adapted from National Research Council 1992)

Biome: Any of several major life zones of interrelated plants and animals determined by the climate (e.g., deciduous forest, desert, etc.).

Bog: A wetland typified by a thick surface layer of floating root mass or peat with an acidic substrate/water. Bogs may have no regular inlet or outlet of water and thus are dependent upon precipitation. Most floating bogs are found in the northern portion of the United States. (Cowardin et al. 1979)

Bottomland Hardwoods: Deciduous forested wetlands found along rivers and streams generally in the broad floodplain areas of the southeast and south central portions of the United States. (Cowardin et al. 1979)

Canopy Layer: The uppermost layer of vegetation in a plant community. In forested wetland areas, mature trees make up the canopy layer, while the tallest herbaceous species constitute the canopy layer in a marsh. (Lewis 1990)

Channelization: Straightening of the meanders in a river system to create more navigable waterways or, when accompanied by channel deepening, to provide flood control. (National Research Council 1992)

Contour: An imaginary line of constant elevation on the ground surface. The corresponding line on a map is called a contour line. (Lewis 1990)

Control of Wastes: Wetlands used to confine acid-mine wastes, chemical contaminants, or fertilizer waste products.

Control Plot: An area of land used to observe or measure existing undisturbed conditions. (Lewis 1990)

Critical Habitat: A natural system necessary for the survival of threatened or endangered species, or species in need of conservation.

Deepwater Habitats: Permanently flooded land lying below the deepwater of wetlands. Deepwater habitats include environments where surface water is permanent and often deep, so that water, rather than air, is the principal medium within which the dominant organisms live, whether or not they are attached to the substrate. As in wetlands, the dominant plants are hydrophytes; however, the substrates are considered nonsoil because the water is too deep to support emergent vegetation. (Dahl and Johnson 1991) 
Density: The number of individual organisms per unit area. (Lewis 1990)

Diameter at Breast Height (DBH): The width of a plant stem as measured at $4.5 \mathrm{ft}(1.4 \mathrm{~m})$ above the ground surface or just above the top of a plant's buttress (if higher than $4.5 \mathrm{ft}$ ). (Lewis 1990)

Dominance: A descriptor of vegetation that is related to the standing crop of a species in an area, usually measured by height, areal cover, density, or basal area (for trees), or a combination of parameters. (Lewis 1990)

Dominant Plant Species: A plant species that exerts a controlling influence on, or defines the character of, a community. (Lewis 1990)

Drained: Condition in which the level or volume of groundwater or surface water has been reduced or eliminated from an area by artificial means. (Lewis 1990)

Drift Line: Accumulation of debris along a contour (parallel to the water flow) that represents the height of an inundation (flood) event. (Lewis 1990)

Duration of Inundation: Length of time that water stands above the soil surface or that water fills most soil pores near the soil surface (soil saturation) (adapted from Alonso and Gorsira 1992).

Ecotone: A transitional zone between two adjacent communities containing species characteristic of both communities as well as other species occurring within the zone.

Edaphic: Of or relating to soil, especially as it affects living organisms (adapted from Alonso and Gorsira 1992).

Emergent Plant: A rooted nonwoody plant that has some parts extending above the water surface, at least during portions of the year, but does not tolerate prolonged inundation. (adapted from Lewis 1990)

Emergent Wetland: Freshwater or saltwater wetlands characterized by free-standing, nonwoody plants. Emergent wetlands are found throughout the United States, particularly in coastal areas, adjacent to major lakes, and in the western portions. (Cowardin et al. 1979)

Endemic Species: An organism native to a region or particular locality. See also Indigenous Species.

Erosion, Wind, and Wave Barriers: Coastal wetlands and wetlands near large lakes and rivers that can reduce the impact of waves and storm tides on upland areas. 
Estuarine System: Deepwater tidal habitats and adiacent tidal wetlands that are usually semienclosed by land but which have open, partly obstructed, or sporadic access to the open ocean, and in which ocean water is at least occasionally diluted by fresh-water runoff from the land. (Cowardin et al. 1979)

Exotic Species: An organism not indigenous to a region, intentionally or accidentally introduced, and often persisting. (adapted from Lewis 1990)

Experimental Plot: An area of land used for measuring or observing conditions resulting from some form of human treatment or alteration (e.g., the planting of a particular species of plant). (adapted from Lewis 1990)

Facultative Species: Plant species that can occur in both wetland and upland environments. There are three subcategories of facultative species: (1) facultative wetland plants (FACW) that usually occur in wetlands with an estimated probability of $67-99 \%$, but are occasionally found in nonwetland areas; (2) facultative plants (FAC) that are equally likely to occur in wetland or nonwetland areas with an estimated probability of 34-66\%; and (3) facultative upland plants (FACU) that usually occur in nonwetland areas with an estimated probability of $67-99 \%$, but are occasionally found in wetland areas (adapted from Alonso and Gorsira 1992).

Fen: A wetland with a defined outlet and supported by mineral-rich groundwater that has seeped to the surface. Like bogs, fens may have large amounts of peat, but they are not acidic. Fens are often found in the northern portion of the United States. (Cowardin et al. 1979)

Fill Material: Any material placed in an area to increase surface elevation. (Lewis 1990)

Fish and Shellfish Habitat: Wetland providing spawning and nursing areas for commercial and recreational fisheries.

Flood Conveyance: A conduit formed in wetlands along the bank of a river to convey floodwater.

Flood Storage: Lowering of flood peaks through the use of inland wetlands acting as reservoirs to store peak discharges of runoff.

Floodplain: Areas periodically inundated (usually annually) by the lateral overflow of rivers or lakes, by direct precipitation, or by groundwater, such that the resulting physiochemical environment causes the biota to respond by morphological, anatomical, physiological, phenological, and/or ethological adaptations to produce characteristic community structures. Hydrologically, the floodplain is delineated by the area flooded at a recurrence interval of once in 100 years. (adapted from National Research Council 1992) 
Forested Wetlands: A wetland dominated by woody vegetation that is at least $20 \mathrm{ft}(6 \mathrm{~m})$ tall. All hydrologic regimes are included except subtidal. (Cowardin et al. 1979)

Frequency (vegetation): The distribution of individuals of a species in an area. It is quantitatively expressed (Lewis 1990) as:

$\frac{\text { Number of samples containing species } \mathrm{A}}{\text { Total number of samples }} \times 100$.

Frequency of Inundation: The periodicity of coverage of an area by surface water or saturation of soil, often expressed as days per year (adapted from Alonso and Gorsira 1992).

Habitat: The environment occupied by individuals of a particular species population or community. (Lewis 1990)

Headwater Flooding: A situation in which an area becomes inundated primarily by surface runoff from upland areas. (Lewis 1990)

Herb: A nonwoody macrophyte. (adapted from Lewis 1990)

Herbaceous Layer: Any vegetative layer of a plant community that is composed predominantly of herbs. (Lewis 1990)

Hydric Soil: A soil that is saturated, flooded, or ponded long enough during the growing season to develop anaerobic conditions favoring the growth and regeneration of hydrophytic vegetation. Hydric soils that occur in areas having positive indicators of hydrophytic vegetation and wetland hydrology are wetland soils. (Lewis 1990)

Hydrologic Regime: The distribution and circulation of water in an area during a given period, including normal fluctuations and periodicity. (Lewis 1990)

Hydrology: The science dealing with the properties, distribution, and circulation of water on and under the earth's surface and in the atmosphere. (Lewis 1990)

Hydrophyte: A macrophyte growing in water or on a substrate that is at least periodically deficient in oxygen as a result of excessive water content; a plant typically found in wet habitats. Obligate hydrophytes require water and cannot survive in dry areas. Facultative hydrophytes may invade upland areas. (Lewis 1990) 
Importance Value: A quantitative term describing the relative influence of a plant species in a plant community, obtained by summing any combination of relative frequency, relative density, and relative dominance. (Lewis 1990)

Indigenous Species: A native organism (not imported or introduced) (adapted from Lewis 1990). See also Endemic Species.

Inundation: A condition in which water from any source temporarily or permanently covers a land surface. (Lewis 1990)

Lacustrine System: Wetlands and deepwater habitats with all the following characteristics: (1) situated in a topographic depression or a dammed river channel; (2) lacking trees, shrubs, persistent emergents, emergent mosses, or lichens with greater than $30 \%$ areal coverage; and (3) total area exceeding 20 acres ( $8 \mathrm{ha})$. Such systems include permanently flooded lakes and reservoirs (e.g., Lake Superior), intermittent lakes (e.g., playa lakes), and tidal lakes with oceanderived salinities of less than $0.5 \%$ (e.g., Grand Lake, Louisiana). (Cowardin et al. 1979)

Landscape: A large land area (typically several square kilometers) that contains a number of different ecosystems, all of which interact spatially and temporally.

Landscape Ecology: An emerging ecological discipline that examines the patterns and processes (both natural and man-made) occurring among a heterogeneous combination of ecological systems that interact spatially and temporally within the same landscape. (adapted from National Research Council 1992)

Macrophyte: Any plant that can be readily observed without the aid of optical magnification. This includes all vascular and nonvascular plants (e.g., Spagnun spp.), as well as large algae (e.g. Chara spp., kelp). (Lewis 1990)

Mangrove Swamp: Coastal saltwater shrub or forested wetland that may be flooded with water all year or only during high tide. Mangrove swamps are found along the coast of the southern United States. (Cowardin et al. 1979)

Marine System: Open ocean overlying the continental shelf and its associated high-energy coastline. Marine habitats are exposed to the waves and currents of the open ocean and the water regimes and are determined primarily by the ebb and flow of oceanic tides. Salinities exceed 30\%, with little or no dilution except outside the mouths of estuaries. The marine system can be either continuously submerged (subtidal) or exposed and flooded by tides, and includes the associated splash zone (intertidal). (Cowardin et al. 1979)

Marsh: An emergent wetland, typically with a regular inlet and outlet of water, that can be either salt or freshwater, inland or coastal. Marshes are dominated primarily by nonwondy vegetation and are located throughout the United States. (Cowardin et al. 1979) 
Mean Sea Level (MSL): A datum, or plane of zero elevation, established by averaging hourly tidal elevations over a 19-year tidal cycle or epoch. This plane is corrected for curvature of the earth and is the standard reference for elevations on the earth's surface. The National Geodetic Vertical Datum (NGVD) is a fixed reference relative to Mean Sea Level that was established in 1929. The relationship between MSL and NGVD is site-specific. (Lewis 1990)

Mesophyte: Any plant growing where soil moisture and aeration conditions lie between extremes. These species are typically found in habitats with average moisture conditions, neither very dry nor very wet. (Lewis 1990)

Natural: Dominated by native biota and occurring within a physical system that has developed through natural processes (without human intervention) and in which natural processes continue to take place. (Lewis 1990)

Nuisance Species: Plant species which detract from or interfere with a mitigation project, such as most exotic species and those indigenous species whose populations proliferate to abnormal portions. Nuisance species may require removal through various types of maintenance programs. (Lewis 1990)

Obligate Wetland Species: Plant species that is nearly always found in wetlands with a frequency of occurrence of $99 \%$ or greater. (adapted from Alonso and Gorsira 1992)

Palustrine System: Includes all nontidal wetlands dominated by trees, shrubs, persistent emergents, emergent mosses or lichens, and all such wetlands that occur in tidal areas where salinity due to ocean-derived salts is below $0.5 \%$. This category groups vegetated wetlands traditionally referred to as marshes, swamps, bogs, fens, and prairies. It also includes the small, shallow, permanent or intermittent water bodies often called ponds. Such areas are found throughout the United States. (adapted from Dahl and Johnson 1991)

Peatland: A generic term for any wetland that accumulates partially decayed plant matter.

Physiognomy: The appearance of a plant community on the basis of its stratification (number of vegetation layers) and the growth habits of the dominant species (e.g., trees, herbs, lianas). (Lewis 1990)

Plant Community: All the plant populations occurring in a shared habitat or environment. (Lewis 1990)

Plant Cover: See Areal Cover. 
Playa: Periodically flooded wetland basins. In the southwestern portion of the United States, playa describes marsh-like ponds similar to potholes but with different geologic origins. (Cowardin et al. 1979)

Pocosins: A broad-leafed evergreen-shrub bog occurring in the southeastern portion of the United States. Such areas may not be readily apparent because the thick underlying peaty soil dries out rapidly after the early part of the growing season. (Cowardin et al. 1979)

Ponded: A condition in which water stands in a closed depression. Water may be naturally removed only by percolation, evaporation, and/or transpiration. (Lewis 1990)

Poorly drained: A soil that is commonly wet at or near the surface during a sufficient part of the year such that field crops cannot be grown under natural conditions. Poorly drained conditions are caused by a saturated zone, low hydraulic conductivity, seepage, or a combination of these conditions. (Lewis 1990)

Prairie Pothole: A depressional wetland (a marsh-like pond) found in the upper Midwest portion of the United States, especially North Dakota, South Dakota, and Minnesota. They are major waterfowl breeding and migration resting areas. (Cowardin et al. 1979)

Productivity: The amount of plant (primary productivity) or animal (secondary productivity) biomass that is generated or accumulated. Usually described in terms of the amount of biomass generated in a particular unit area per year. (adapted from Lewis 1990)

Quantitative: A precise measurement or determination expressed numerically. (Lewis 1990)

Recreational wetlands: Recreational opportunities such as fishing, hunting, bird-watching, canoeing, and camping that are provided by a wetland environment.

Reed Swamp: Marsh dominated by Phragmites communis (common reed).

Relative Density: The number of individuals of a single species expressed as a percentage of the total density (Lewis 1990), expressed as

$$
\frac{\text { Number of individuals of species } \mathrm{A}}{\text { Total number of individuals of all species }} \times 100 \text {. }
$$


Relative Dominance: The amount of one species as a percentage of the total amount of all species in an area, expressed as

$$
\frac{\text { Amount of species }}{\text { Total amount of all species }} \times 100 \text {. }
$$

The amount of a species may be based on percent areal cover, basal area, biomass, or height. (Lewis 1990)

Relative Frequency: The distribution of one species as a percentage of the total frequency of all species in the area (Lewis 1990), expressed as:

$$
\frac{\text { Frequency of Species } \mathrm{A}}{\text { Total frequency of all species }} \times 100 \text {. }
$$

Relief: The change in elevation of a land surface between two points; collectively, the configuration of the earth's surface, including such features as hills and valleys. (Lewis 1990) See also Topography.

Riparian Vegetation: Hydrophytic vegetation growing in the immediate vicinity of a lake or river such that annual evapotranspiration represents a factor in the lake or river regimen. (National Research Council 1992)

Riparian Zone: The border or bank of a stream. Although this term is sometimes used interchangeably with floodplain, the riparian zone is generally regarded as relatively narrow compared to a floodplain. The duration of flooding is generally much shorter and the timing less predictable in a riparian zone than in a river floodplain. (National Research Council 1992)

Riverine System: All wetlands and deepwater habitats contained within a channel, with two exceptions: (1) wetlands dominated by trees, shrubs, persistent emergents, emergent mosses, or lichens, and (2) habitats with water containing ocean-derived salts in excess of $0.5 \%$. Water is usually, but not always, flowing in a riverine system (Cowardin et al. 1979). Riverine wetlands are categorized according to such flow regimes as tidal waters, slow-moving waters with welldeveloped floodplains, fast-moving waters with little floodplain, and intermittent systems. (National Research Council 1992)

Sample Plot: An area of land used for measuring or observing existing biotic and abiotic conditions. (Lewis 1990)

Saturated Soil: A condition in which all easily drained pores between soil particles are temporarily or permanently filled with water, with a significant saturation during the growing season, considered to be one week or greater. (adapted from Alonso and Gorsira 1992) 
Scrub-Shrub Wetlands: Areas dominated by woody vegetation less than $20 \mathrm{ft}(6 \mathrm{~m})$ tall. Species include true shrubs, young trees, and trees or shrubs that are small or stunted because of environmental conditions. All water regimes except subtidal are included. (adapted from Dahl and Johnson 1991)

Sediment control: The use of wetlands to contrcl the deposition of sediments by reducing the velocity of flood waters.

Self-Maintaining System: An ecosystem that can perform all of its natural ecological functions without human intervention.

Shrub Wetland: See Scrub-Shrub Wetlands.

Slope: A ground surface that is not level. (Lewis 1990)

Slough: An elongated marsh often dissected by a creek with slowly flowing surface water. Sloughs are often associated with riverine systems.

Spatial Heterogeneity: The complex spatial pattern of ecosystems across a landscape. (adapted from National Research Council 1992)

Substrate: The base or substance on which an attached species is growing. (Lewis 1990)

Swamps: A wetland dominated primarily by trees or shrubs. Swamps are found throughout the United States.

Tidal: A situation in which the water level fluctuates periodically as a result of the action of lunar and solar forces upon the rotating earth. (Lewis 1990)

Timber Use: Use of forested wetlands as a source of wood at competitive prices, despite physical problems associated with working in a wet environment.

Topography: The configuration of a surface, including its relief and the position of its natural and man-made features. (Lewis 1990) See also Relief.

Transect: A line on the ground along which biotic and abiotic observations are made at certain intervals. (adapted from Lewis 1990)

Tree: A woody plant $>3.0 \mathrm{in} .(>8.5 \mathrm{~cm})$ in diameter at breast height $(\mathrm{DBH})$, regardless of height (exclusive of woody vines). (Lewis 1990) 
Vernal pool: A naturally occurring depressional wetland covered by shallow water for variable periods from winter to spring. Such wetlands may be completely dry for most of the summer and fall.

Water Quality: A measure of physical, biological, chemical, and aesthetic characteristics and attributes of water as defined by state and federal regulatory standards.

Water Supply: Wetland functions by which rainwater is stored or underground water supplies are recharged. Stored water is commonly used as a source of water for urban areas and for livestock use and crop irrigation.

Water Table: The upper surface of ground water or that level below which the soil is saturated with water. (Lewis 1990)

Waterfowl Habitat: Nesting areas provided by inland and coastal wetlands for many species of birds, some of which are threatened and endangered.

Watershed: The entire surface drainage area that contributes water (via surface and subsurface flows) to a lake or river. (adapted from National Research Council 1992)

Watershed-Scale Approach: A consideration of the entire watershed, including the land mass that drains into the aquatic ecosystem. (National Research Council 1992)

Wet Prairie/Wet Meadow: Grassland area with waterlogged soil near the surface, but without standing water for most of the year. Such areas are similar to marshes. (Cowardin et al. 1979)

Wetland-Dependent: Species which frequently reside in a wetland environment or have critical life-cycle requirements met by a wetland rather than nonwetland environment.

\section{A.4 Bibliography for General Wetland Definitions}

The general wetland definitions were taken or adapted from some of the following sources:

Alonso, J., and R. Gorsira, 1992, "Current Trends in Identifying and Delineating Federal Jurisdictional Wetlands," Journal of Environmental Regulation, Summer.

Broome, S., 1990, "Creation and Restoration of Tidal Wetlands of the Southeastern United States," in Wetland Creation and Restoration, the Status of the Science, J. Kusler and M. Kentula (editors), Island Press, Washington D.C. 
Burke, D., et al., 1988, Protecting Nontidal Wetlands, Report No. 412/413, American Planning Association, Chicago, Illinois.

Cowardin, L.M., et al., 1979, Classification of Wetlands and Deepwater Habitats of the United States, FWS/OBS-79/31, prepared for U.S. Fish and Wildlife Service, Office of Biological Services, U.S. Government Printing Office, Washington, D.C.

Dahl, T., and C. Johnson, 1991, Status and Trends of Wetlands in the Conterminous United States, Mid-1970's to Mid-1980's, U.S. Department of the Interior, Fish and Wildlife Service, Washington D.C.

Erwin, K., 1990, "Freshwater Marsh Creation and Restoration in the Southeast," in Wetland Creation and Restoration, the Status of the Science, J. Kusler and M. Kentula (editors), Island Press, Washington D.C.

Lewis III, R., 1990, "Wetlands Restoration/Creation/Enhancement Terminology: Suggestions for Standardization," in Wetland Creation and Restoration, the Status of the Science, J. Kusler and M. Kentula (editors), Island Press, Washington D.C.

National Research Council, 1992, Restoration of Aquatic Ecosystems: Science, Technology, and Public Policy, Water Science and Technology Board, Washington D.C.

Steen, E., 1971, Dictionary of Biology, Barnes \& Noble Books, Division of Harper \& Row Publishers, New York, N.Y.

U.S. Fish and Wildlife Service, 1981, U.S. Fish and Wildlife Service Mitigation Policy, Federal Register 46(15):7644-7663. 


\section{Appendlx B:}

Summary of Wetland Mitigation Bank Characteristics 


\section{Appendlx B:}

\section{Summary of Wetland Mitigation Bank Characteristics}

\section{B.1 Bowers Hill Wetland Mitigation Bank}

\section{B.1.1 General Information}

$\begin{array}{ll}\text { Location: } & \text { Bowers Hill, Virginia } \\ \text { Size: } & 11 \text { acres } \\ \text { Started: } & 1983 \\ \text { Owner: } & \text { Virginia Department of Transportation } \\ \text { User: } & \text { Virginia Department of Transportation } \\ \text { Mitigation: } & \text { In-kind, in-basin }\end{array}$

The Bowers Hill Wetland Mitigation Bank is a man-made subtidal salt marsh created in a highway construction borrow area. The marsh is rectangular in shape, with an elevation depressed approximately 6-8 $\mathrm{ft}$ from the surrounding upland and decreasing a total of $3 \mathrm{ft}$ from the south to north end.

\section{B.1.2 Ecological Characteristics}

$\begin{array}{ll}\text { Wetland System: } & \text { Estuarine } \\ \text { Wetland Type: } & \text { Subtidal salt marsh } \\ \text { Bank Origin: } & \text { Creation }\end{array}$

Common reed (Phragmites australis) dominates the higher elevations and spartina dominates the lower elevations of the Bowers Hill bank. The banks slope at about a 3:1 ratio and are transitional to the surrounding upland. Marsh vegetation and some deciduous trees cover the banks. A meandering creek flowing through the center of the lower marsh maintains the hydrology. The creek flows into a tidally influenced stream at the north end of the site, allowing brackish water to enter during high tides. The marsh vegetation was imported from nearby wetlands and planted as a part of the mitigation bank development by the Virginia Department of Transportation (VDOT). The Bowers Hill Wetland Mitigation Bank is ecologically effective in that the wetland is a self-sustaining wetland of the type designed. 


\section{B.1.3 Economic Characteristics}

The total costs associated with development of the Bowers Hill Wetland Mitigation Bank are difficult to identify. The construction of the bank was financed in conjunction with the construction of an adjacent highway. Researchers from a project within the state university system planted the vegetation. There is little to no maintenance cost because a self-sustaining marsh system has been created.

The transactions at the bank have been on a square-footage basis, with a mitigation ratio of $1: 1$. VDOT has mitigated for impacts as small as in the hundreds of square feet. The method of debiting requires prior approval of the regulators involved in VDOT development. Account balances are monitored on the number of uncommitted square feet. VDOT believes there are clear but undocumented savings associated with permitting wetland mitigation action by having the bank.

\section{B.1.4 Management and Regulatory Characteristics}

$\begin{array}{ll}\text { Owner: } & \text { Virginia Department of Transportation } \\ \text { Operator: } & \text { Virginia Department of Transportation } \\ \text { Long-Term Steward: } & \text { Virginia Department of Transportation } \\ \text { Federal Regulators: } & \text { U. S. Army Corps of Engineers } \\ & \text { U. S. Environmental Protection Agency } \\ & \text { U. S. Fish and Wildlife Service } \\ & \text { National Marine Fisheries Service } \\ & \text { Virginia State Water Control Board } \\ \text { State Regulators: } & \text { Virginia Marine Resources Commission } \\ & \text { Virginia Game Commission } \\ & \text { Virginia Fish and Game }\end{array}$

VDOT is the sole owner and user of the bank. While no formal banking procedures are in place, each withdrawal from the bank requires approval by a subset of the regulators (listed above), which control VDOT development projects. VDOT does not have a formal monitoring program for maintaining the bank. Periodic inspections assure that no gross changes in the bank configuration, especially the hydrology, have occurred. VDOT maintains a ledger sheet of actual debits against the bank and also of proposed and approved future withdrawals, thus assuring a negative bank balance. The management of this bank appears to be effective for VDOT mitigation projects.

\section{B.1.5 Special Issues/Concerns}

None identified. 


\section{B.2 Chimento Wetland Mitigation Bank}

\section{B.2.1 General Information}

$\begin{array}{ll}\text { Location: } & \text { Borough of Little Silver, New Jersey (Monmouth County) } \\ \text { Size: } & 21 \text { acres (17 acres available for banking) } \\ \text { Hydrologic Basin/Unit: } & \text { Shrewsbury River } \\ \text { Started: } & 1988 \\ \text { Date Operational: } & \text { In final design/planning stage } \\ \text { Owner/Operator: } & \text { Mr. John Chimento } \\ \text { Users: } & \text { Any private or public organization/agency } \\ \text { Mitigation: } & \text { In-kind, in-region }\end{array}$

The Chimento Wetland Mitigation Bank is a private venture. It received final plan approval from the New Jersey Department of Environmental Protection, Freshwater Wetlands Mitigation Council, on April 14, 1992. Appropriate state and federal permits must be issued and the final mitigation bank plan and wetland restoration design reviewed by the U.S. Environmental Protection Agency before it can become operational.

\section{B.2.2 Ecological Characteristics}

Wetland System: Mixed estuarine and palustrine

Wetland Type: Coastal marsh

Bank Origin: Restoration

The Chimento site is a 21 -acre mixed marine, estuarine, and palustrine coastal wetland system. About 17 acres, 5 acres of saltwater marsh and 12 acres of freshwater habitats, will be available for mitigation purposes. Water enters the wetland through tidal influence, springs, and groundwater and leaves through a combination of evapotranspiration and surface discharge into the marine/estuarine system.

Most of the area was used as a dredge material disposal site during the early 1950s. The site is bounded by Town Neck Creek to the south (a tributary of the Shrewsbury River) and private properties and homes to the north. A uniformly colored, dark, grayish-brown mixture of highorganic, high-clayey, fine silt with a sandy material cover the entire spoil-disposal area (Edstrom 1992).

During a recent drought period (1986-1988), most of the site was completely void of vegetation. In the intervening years, the herbaceous vegetation increased, with about a $50 \%$ mixture of facultative plants (both wetland and upland). Depending upon the elevation level, major facultative wetland plant species include Phragmites australis (the common reed), Juncus effusus 
(soft rush), Phalaris virginica (reed canary grass), Scirpus cyperinus (wool grass), Calamagrostis canadensis (blue joint reedgrass), and Spartina patens (Salthay). Wildlife species observed at the site are typical for the region (e.g., rabbit, raccoon, opossum, muskrat, blackbirds, sparrows, starlings, etc.).

\title{
B.2.3 Economic Charactoristics
}

$\begin{array}{ll}\text { Costs: } & \text { Not available } \\ \text { Currency: } & \text { Acreage } \\ \text { Original Credit: } & 17 \text { acres } \\ \text { Current Credit: } & 17 \text { acres }\end{array}$

Bank credits are based on acreage and sold in 0.1 acre units. It is anticipated that units of credit will be sold, traded, or transferred. Determination of the unit prices for bank credits will involve costs for land acquisition, earthwork engineering, and revegetation. A New Jersey state policy requires a 2:1 ratio for mitigating coastal wetlands. Possibly greater ratios may be required due to some enhancement activity on the site. At present, no transactions or negotiations are known to have occurred.

\section{B.2.4 Management and Regulatory Characteristics}

\author{
Owner/Manager: $\quad$ Mr. John Chimento \\ Developer/Designer: Mr. Oliver Edstrom (609) 965-4034 \\ Long-Term Steward: Mr. John Chimento \\ Federal Regulator: U.S. Army Corps of Engineers \\ State Regulator: New Jersey Department of Environmental Protection, Division \\ of Coastal Resources
}

A family corporation will be established to manage the bank and administer the banking credit units once all regulatory approvals are completed. The New Jersey Wetlands Mitigation Council will continue to monitor bank management at least until all the bank credits are sold.

The primary management objective is to establish various estuarine environments. Increased bank value will result from both wetland and upland areas, providing greater overall habitat diversity. The bank will be managed for five basic types of ecological communities: (1) tidal wetlands, (2) brackish wetlands, (3) freshwater wetlands, (4) hardwood wetlands, and (5) uplands. Construction of the bank will be in several phases. Monitoring stations will be established at the site, and data will be collected, evaluated, and reported to the New Jersey Department of Environmental Protection on an annual basis.

The Chimento Wetland Mitigation Bank received final plan approval from the New Jersey Department of Environmental Protection, Freshwater Wetlands Mitigation Council, on April 14, 
1992. The plan must now receive appropriate state and federal permits (e.g., U.S. Army Corps of Engineers) and a review by the U.S. Environmental Protection Agency before becoming operational.

\section{B.2.5 Special Issues/Concerns}

A major problem in attempting to develop this wetland mitigation bank was obtaining concurrence from all the state and federal regulatory and commenting agencies. Regulatory agencies feared acceptance of a mitigation bank would set precedent and allow for easy approval of the filling of wetlands, because the bank would be available for use by all private developers. However, this fear is unfounded as long as the program is properly administered by the regulatory agencies. The effectiveness of this bank cannot be evaluated due to the early stage of development.

\section{B.3 Creeds Wetland Mitigation Bank}

\section{B.3.1 General Information}

Location: Virginia Beach, Virginia

Size: $\quad 47$ acres

Started: $\quad 1992$

Owner: $\quad$ City of Virginia Beach

User: $\quad$ City and private developers

Mitigation: In-kind, in-watershed, in-city

The Creeds Wetland Mitigation Bank is a 47 -acre site being pursued by the City of Virginia Beach, Virginia, for open use with the city. Credits are scheduled to be available for purchase in 1993.

\section{B.3.2 Ecological Characteristics}

$$
\begin{array}{ll}
\text { Wetland System: } & \text { Estuarine } \\
\text { Wetland Type: } & \text { Marsh } \\
\text { Bank Origin: } & \text { Restoration }
\end{array}
$$

The Creeds bank is a historic agricultural site being allowed to return to its natural wetland state. Until the 1990 growing season, the site had been farmed in a variety of crops. In the spring of 1992, the site had considerable coverage of juncus emerging from among the upland grasses established after the site became fallow. The site is surrounded on all sides by a stand of deciduous trees. The City of Virginia Beach has established a small experimental plot, with a 
planting of cypress seedlings near the center of the site. The survival rate has been high, and the seedlings will be monitored as the site progresses toward being a wetland.

The soils appear to be drained hydric in nature. Cropland drainage has been by a series of pa allel ditches flowing west to east across the site. At the east end, the ditches are intersected by a collector ditch, which carries the flow south and east to Back Bay. Discharge from the collector ditch, controlled by an overflow weir, is being used to raise the elevation of the water in the ditches. By raising the water level in the ditches, the water table between the ditches will also rise, promoting a return to hydric soils and vegetation. The water table is being monitored from a series of simple wells, to establish the hydrologic baseline across the site. The bank is scheduled to mitigate off-site, in-kind acreage of impacted estuarine marsh throughout the county. Other banks are planned by the county to mitigate other anticipated wetland impacts.

\section{B.3.3 Economic Characteristics}

$\begin{array}{ll}\text { Costs: } & \text { Not available } \\ \text { Currency: } & \text { Acreage } \\ \text { Original Credit: } & 47 \text { acres } \\ \text { Current Credit: } & 47 \text { acres }\end{array}$

The credit and currency system has yet to be clearly defined at the Creeds Mitigation Bank. The common currency and credit measure in the Virginia Beach area has been acreage. The currency will be established under a memorandum of agreement (MOA) now in final negotiation with the regulators. Ratios may be used that are set on the basis of the quality of the impacted wetlands in relation to the developing quality of the wetland bank acreage. The actual credits and debits may be evaluated by the Wetland Evaluation Technique (WET), Habitat Evaluation Procedure (HEP), best professional judgment, or other methods determined appropriate by the Mitigation Review Team (MRT), as specified in the MOA. Each case considered for mitigation bank usage will be treated individually. The City of Virginia Beach will be responsible for maintaining a ledger of accounts for the bank. The MRT and other interested agencies will be provided with an accounting of bank status on at least a semiannual basis.

\section{B.3.4 Management and Regulatory Characteristics}

Owner:

Operator:

Long-Term Steward:

Federal Regulators:
City of Virginia Beach

City of Virginia Beach

City of Virginia Beach

U. S. Army Corps of Engineers

U. S. Environmental Protection Agency

U. S. Fish and Wildlife Service

National Marine Fisheries Service 
State Regulators: $\quad$ Virginia State Water Control Board

Virginia Marine Resources Commission

The Creeds Wetland Mitigation Bank will be owned and managed by the City of Virginia Beach. The property is owned by the city and abuts a police training facility at an abandoned civil defense airport near the Virginia coastline and Back Bay. Banked acreage is planned for use only within the City. The acreage will be available for both city and private development. The City of Virginia Beach negotiated an MOA with the U.S. Army Corps of Engineers to establish the proper regulatory channels to facilitate and implement bank use. Wetland impacts remain subject to sequencing before they reach the Creeds opportunity. The city believes that the banking option will facilitate permit actions, while complying with the policy of no overall net loss.

Withdrawals from the bank will be approved and controlled by the MRT, which consists of representatives from the City of Virginia Beach and the overseeing regulators (see list above). The MRT consolidates most of the regulators into a single entity with coordination through monthly interagency meetings. The city is responsible for locating the bank, preparing a bank development plan, and coordinating the plan with the Corps, State Water Control Board, and Virginia Marine Resources Commission prior to submittal to the MRT for review. Development, operation, and long-term maintenance and monitoring of the bank are also City of Virginia Beach responsibilities. Monitoring is scheduled to be performed at 1, 2,3,5, and 10 years after construction. The MRT will develop monitoring criteria for each bank during the site approval process. The Creeds bank will be part of a banking system managed by the city along with other potential banks proposed in other watersheds within the City. The final terms of the MOA were not available at this time.

\section{B.3.5 Special Issues/Concerns}

Two issues of significance were encountered in the development of the plan to create the Creeds Wetland Mitigation Bank. First, the City Public Works Department was required to build political consensus at the local level. Once the support was achieved, the MOA required careful negotiation to satisfy the environmental and developmental concerns raised by the city as a political entity. The second issue was receiving funding to go forward with the project. The funding issue was resolved shortly after a political consensus was achieved. The key to creating the Creeds Bank was the integration of the bank into the overall land-management program. The effectiveness of this bank cannot be evaluated due to the early stage of development.

\section{B.4 Fina LaTerre, Inc., Wetland Mitigation Bank}

\section{B.4.1 General Information}

Location: $\quad$ Theriot, Louisiana (Terrebonne Parish)

Size: $\quad$ 7,200 acres (5,000 acres available for banking) 


$\begin{array}{ll}\text { Hydrologic Basin/Unit: } & \text { Terrebonne Basin } \\ \text { Started: } & \text { Memorandum of Agreement (January 1984) } \\ \text { Date Operational: } & 1985 \\ \text { Owner/Operator: } & \text { Fina LaTerre, Inc. } \\ \text { User: } & \text { Fina LaTerre, Inc. and others } \\ \text { Mitigation: } & \text { In-watershed, in-kind }\end{array}$

The Fina LaTerre Wetland Mitigation Bank has been operating since the mid-1980s as a private development. The rationale (from a company perspective) behind mitigation bank development was (1) to reduce the uncertainty of obtaining regulatory permits, (2) to obtain credit for (marsh) management actions, and (3) to integrate the concept of mitigation into future land management plan options considered by upper-management decision makers (Soileau 1984).

\section{B.4.2 Ecological Characteristics}

$\begin{array}{ll}\text { Wetland System: } & \text { Estuarine, lacustrine } \\ \text { Wetland Type: } & \text { Coastal marsh } \\ \text { Bank Origin: } & \text { Restoration/enhancement/preservation }\end{array}$

Until the mid-1950s, the region was a homogeneous freshwater marsh dominated by Panicum himitomon (maidencane) (Short 1988). As a consequence of the construction of navigation and oil exploration canals, natural subsidence, and hurricanes, the freshwater marshes along the coast have been converting to saltwater marshes and open water.

The site consists of marsh, adjacent shallow open water areas, and natural levees formed by past soil depositions of the Mississippi River (Soileau 1984). The freshwater habitat supports a variety of wintering birds, nesting and wading birds, alligators, fur-bearing animals, and a number of fish and shellfish species (Fina LaTerre, no date). Spartina patens (wiregrass) dominates both fresh and brackish water areas, along with Panicum hemitomon (maidencane), Typha latifolia (cattail) in the freshwater marsh, and Distichlis spicata (saltgrass) in the brackish marsh. The predominant woody vegetation of the shrub/scrub habitat is Myrica cerifera (wax myrtle) (Soileau 1984). Without diking and damming efforts, estimates for subsidence sufficient to allow for saltwater intrusion are approximately 77 years, which would result in losing the freshwater habitat.

\section{B.4.3 Economic Characteristics}

Costs:

Construction and Planning:

OperationMaintenance:

Currency:

Original Credit.

Current Credit:
Approximately $\$ 2.5$ million total costs to date

Approximately $\$ 100 /$ acre

$\$ 0.5$ million (over life of project)

Habitat units

8.5 million habitat units

About 7.65 million habitat units 
Credits have been used by Tenneco and Fina, and a number of credits have been made available to other parties. In addition to cost savings/revenue from sales of credits, the area provides several harvestable commodities, including alligator eggs and nutria. The area is also used for recreational fishing and hunting.

Unlike the case at most mitigation banks, oil exploration and extraction activities have occurred within the site. These impacts have been offset by credits available to the bank. After the development impacts have occurred, the stated goal is to restore the impacted area to its previous state, if possible. The unique nature of the impacts successfully allows development and mitigation within the bank.

An interagency team consisting originally of the Tenneco LaTerre Corporation (now Fina LaTerre, Inc.) and the oversight regulatory agencies, with the U.S. Fish and Wildlife Service (USFWS) acting as chair, was responsible for determining the number of habitat units and the average annual habitat units initially credited to the bank (Short 1988). The credit system habitat units were derived from formulas developed in the USFWS Habitat Evaluation Procedures (HEP) manual. The HEP76 procedures (unmodified) were considered to work well, according to the USFWS (Short 1988). HEP76 was selected over HEP80 because of the more rapid method of analysis.

The number of habitat units determined by the HEP evaluation allowed credit for such management practices as installing weirs, bulkheads, and earthen dam enclosures. Over time, establishment of 11.9 million habitat credit units is estimated. Because 3.4 million habitat units will occur on approximately 2,200 acres of land not owned by Fina LaTerre Inc., only 8.5 million will be available for banking purposes (Fina LaTerre, Inc. undated). The number of credits in the bank has been renegotiated several times. One reduction of credits was restored when it was determined that adjacent property was benefiting from bank management activities. Credits were later lowered because Tenneco only guaranteed intensive management of the bank for the first 25 years. The amount of credits will be reevaluated (using a full HEP analysis) after the end of the 25-year period (Short 1988).

Bank credits are generally applied toward in-kind mitigation within the same hydrologic unit. Credits for mitigation outside the hydrologic units will be considered by the interagency committee on a case-by-case basis. In some cases, credits gained at one location within certain types of wetlands can be applied to debits for unavoidable damages at another location in the state. There must be a corresponding credit-to-debit exchange in terms of mitigating specific types of habitat losses. In other words, wildlife losses must be offset by wildlife credits, freshwater fishery losses by freshwater fishery credits, estuarine fishery losses by estuarine fishery credits, etc. Credits can be bought, traded, or sold, as long as the interagency review team concurs. 


\title{
B.4.4 Management and Regulatory Characteristics
}

\author{
Owner/Manager: $\quad$ Fina LaTerre, Inc. \\ Developer/Designer: Tenneco LaTerre Corp. in conjunction with U.S. Fish and \\ Wildlife Service and Louisiana Department of Fish \& Game \\ Long-Term Steward: Fina LaTerre, Inc. \\ Federal Regulators: U.S. Fish and Wildlife Service \\ National Marine Fisheries Service \\ U.S. Soil Conservation Service \\ State Regulators: $\quad$ Department of Wildlife and Fisheries Coastal Management \\ Section of the Louisiana Department of Natural Resources
}

The management program was initially developed by Tenneco LaTerre Corp. in conjunction with the U.S. Soil Conservation Service. It is overseen by an interagency review committee, chaired by the USFWS, consisting of Fina LaTerre, Inc., and the listed oversight regulatory agencies. Currently, the company's responsibility is implementation of the plan and the mitigation bank enhancement measures designed to reduce the level of saltwater intrusion into the management area. The plan requires increasing freshwater and sediment inflow, improving water circulation, and stabilizing water levels (Soileau 1984; Short 1988). The bank area provides waterfowl habitat managed for hunting and supports a significant amount of trapping and alligatoregg collecting activities. Fina LaTerre, Inc., has at least a 25 -year commitment to preserving the integrity of the wetlands. An MOA was signed in January 1984, and the bank became operational the following year.

\section{B.4.5 Special Issues/Concerns}

Initial problems of coordination between and within the various agencies involved in the bank appear to have been rectified. From the perspective of the USFWS, there continue to be problems in computing debits and credits for the bank. In addition, the whole banking process is time-consuming and has encountered a number of administrative difficulties. From a positive perspective, the mitigation banking process does help ensure that mitigation has taken place and that the level of effectiveness is known. In other words, some of the uncertainties concerning the level of effectiveness, or even whether the mitigation has occurred at all, have been lessened. The Fina LaTerre bank has proven effective in creating the expected habitats and improving the quality of the wetland. The management structure involving USFWS has proven cost-effective for the owner, Fina LaTerre, Inc..

\section{B.5 Minnesota Wetland Mitigation Banking System}

The Minnesota Department of Transportation (MnDOT) has developed a mitigation banking system to routinely deal with transportation development impacts. Every MnDOT region has at least one mitigation bank from which all MnDOT developments may draw credits. The banking 
system has been created in conjunction with the Minnesota Department of Natural Resources

(MnDNR). Three of the MnDOT wetland mitigation banks are described below.

\title{
B.5.1 Prairle Pothole
}

\section{B.5.1.1 General Information}

Location: $\quad$ Minnesota Department of Transportation

Size: $\quad$ Three units, ranging from 3 to 25 acres

Hydrologic Basin/Unit: Not available

Started: $\quad$ 1989-1990

Date Operational: $\quad$ 1989-1992

Owner/Operator: $\quad$ Minnesota Department of Transportation

U.S. Fish and Wildlife Service

User: $\quad$ MnDOT

Mitigation: In-kind, in-highway-district

\section{B.5.1.2 Ecological Characteristics}

\author{
Wetland System: Palustrine \\ Wetland Type: Prairie potholes, bottomland hardwoods \\ Bank Origin:: Creation, enhancement, restoration
}

The first unit of 25 acres was owned by the USFWS and was known as Eng Lake WPA. It was originally wetland but is currently being drained by a tile line. A riser was installed to impound the water. Credit of 525 habitat units was awarded in April 1992. The second unit of 25.1 acres was purchased from the owner as dry wetland and upland. Installation of a riser increased the water elevation to $1,390 \mathrm{ft}$, flooding the wetland and upland area. Credit of 1,108 habitat units was awarded in April 1992. The third unit of 3 acres was under private ownership, which requested that the District install a centerline culvert to add drainage to the basin as on-site mitigation.

\section{B.5.1.3 Economic Characteristics}

$\begin{array}{ll}\text { Costs } & \\ \text { Planning/Development: } & \$ 17,000 \text { (land acquisition) } \\ \text { Construction: } & \$ 7(10-\$ 1000 \\ \text { Currency: } & \text { Habitat units }\end{array}$


$\begin{array}{ll}\text { Original Credit: } & 95 \text { to } 1,750 \\ \text { Current Credit: } & \text { Not available }\end{array}$

The MnDOT uses a HEP system for mitigation banking. The sites are occasionally monitored to assess effectiveness and for reclassification and recalculation of available credits. The only eligible user of MnDOT banks is MnDOT. Credit use is relatively flexible, with any MnDOT project within an MnDOT administrative region able to draw credits from any MnDOT bank in the region.

\section{B.5.1.4 Management and Regulatory Characteristics}

$\begin{array}{ll}\text { Owners/Managers: } & \begin{array}{l}\text { Minnesota Department of Transportation } \\ \text { U.S. Fish and Wildlife Service } \\ \text { Private owner }\end{array} \\ \text { Developers/Designers: } & \begin{array}{l}\text { Minnesota Department of Transportation } \\ \text { U.S. Fish and Wildlife Service } \\ \text { Private owner }\end{array} \\ \text { Long-Term Stewards: } & \begin{array}{l}\text { Minnesota Department of Transportation } \\ \text { U.S. Fish and Wildlife Service }\end{array} \\ & \begin{array}{l}\text { Private owner } \\ \text { Federal Regulators: }\end{array} \\ & \text { U.S. Fish and Wildlife Service } \\ & \text { U.S. Army Corps of Engineers } \\ \text { State Regulators: } & \text { Minnesota Department of Transportation } \\ & \text { Minnesota Department of Natural Resources }\end{array}$

MnDNR and MnDOT determine the site of the mitigation bank and the type of bank desired. MnDOT is primarily responsible for all monitoring, maintenance, administration, and evaluation activities, with the aid of MnDNR, Federal Highway Administration, and USFWS.

As part of their interagency agreement, MnDOT must first investigate the applicability of on-site mitigation. If on-site mitigation is found to be too expensive or ineffective, the development project may acquire bank credits. No preapproval is required for drawing on bank credits.

\section{B.5.1.5 Special Issues/Concerns}

As of November 1992, a Minnesota state-wide system of mitigation banking was to be considered for all developers and users. The outcome is uncertain at present. 


\title{
B.5.2 Wawina Lake Restoration
}

\section{B.5.2.1 Goneral Information}

$\begin{array}{ll}\text { Location: } & \text { Itasca County, Minnesota Department of Transportation, District } 1 \\ \text { Size: } & 310 \text { acres } \\ \text { Started: } & 1989-1990 \\ \text { Owner: } & \text { Minnesota Department of Transportation } \\ \text { User: } & \text { Minnesota Department of Transportation, district } 1 \\ \text { Mitigation: } & \text { In-kind, in-basin } \\ \text { Mitigation: } & \text { In-kind, in-district }\end{array}$

\section{B.5.2.2 Ecological Characteristics}

\author{
Wetland System: Palustrine \\ Wetland Type: Freshwater lake \\ Mitigation: In-district bank \\ Bank Origin: Lake restoration
}

Wawina Lake was a shallow lake in the late stages of eutrophication, but it was still supporting wild rice and northern pike before it was drained in 1910. The 1860 survey notes indicate that the entire area south and east of the lake was nearly treeless. There is a stand of 60- to 70-year-old trees, but the District Forester felt these grew after earlier fires rather than after the original drainage. The lake now has a layer of $15-20 \mathrm{ft}$ of muck that developed before the drainage. The center was an open area with emergent swamp grass, ringed by cattails, sedges, and brush 100-200 meters wide, then foilowed by forest. There is a ground rise to the first 100 yards of trees. Wildlife include beaver, sandhill crane, mallards, teal, bitterns, and moose.

The water level will be raised six inches at a time by a water-control structure impounding the flow of a judicial ditch. The lake is public water surrounded by private lands with black spruce/tamarack forest. Reimbursement to landowners for the flooding of private timber with the rising water was offered. Dead trees would increase the wildlife value for nesting and migrating waterfowl, but they might detract from the aesthetics, as viewed from the road. An active public education program was advocated with newspaper articles and interpretive signs on the site to explain the process. 


\section{B.5.2.3 Economic Characteristics}

Costs: $\quad$ \$65/acre

Currency: Habitat units

Original Credit. $\quad 12,090$ habitat units

Current Credit: Not available

\section{B.6.2.4 Management and Regulatory Charactoristics}

\begin{tabular}{|c|c|}
\hline Owner/Manager: & Minnesota Department of Transportation \\
\hline Developer/Designer: & Minnesota Department of Transportation \\
\hline Long-Term Steward: & Minnesota Department of Natural Resources \\
\hline Federal Regulators: & $\begin{array}{l}\text { U.S. Army Corps of Engineers } \\
\text { U.S. Fish and Wildlife Service }\end{array}$ \\
\hline State Regulator: & Minnesota Department of Natural Resources \\
\hline
\end{tabular}

\section{B.6.2.5 Special Issues/Concerns}

When the water level began to rise, part of the sedge bog floated in the summer and apparently sunk in the winter. It is uncertain whether this mat will eventually sink permanently, creating a large body of open water. Currently, there are ponds of open water between the higher floating mats.

\section{B.5.3 Staples Mitigation Bank}

\section{B.5.3.1 General Information}

Location: Staples, Todd County, Minnesota, Minnesota Department of Transportation, District 3

Size: $\quad 670$ acres

Started: $\quad$ Summer 1988

Owner: Minnesota Department of Transportation

Mitigation: In-kind, in-district

User: $\quad$ Minnesota Department of Transportation, District 3 


\section{B.5.3.2 Ecological Characterietics}

Wetland System: Palustrine

Wetland Type: $\quad$ Freshwater marsh, lake

Bank Origin: Restoration

\section{B.5.3.3 Economic Charactoristics}

\begin{tabular}{|c|c|}
\hline Costs: & $\begin{array}{l}\$ 314,000 ; \$ 469 / \text { acre } \\
\$ 18.000 \text { (land acquisition }\end{array}$ \\
\hline Planning/Development: & $\$ 18,000$ (land acquisition \\
\hline Construction: & $\$ 296,000$ \\
\hline Currency: & Habitat units \\
\hline Original Credit: & 32,250 habitat units \\
\hline Current Credit: & Not available \\
\hline
\end{tabular}

The MnDNR urged the MnDOT to evaluate restoration of the Rice Lake basin in the Staples Wildlife Preserve as a potential mitigation site. MnDOT purchased 120 acres adjacent to the preserve to restore the entire basin. Construction included $3.1 \mathrm{mi}$ of dikes, a sheet-pile watercontrol structure with removable stop blocks, a public parking area, 18 half-acre nesting islands, and 12 experimental 6-ft islands. The entire project was finished in September 1989. The initial HEP based on the design credited a gain of 32,250 habitat units, which was confirmed at the conclusion of construction.

\section{B.5.3.4 Management and Regulatory Characteristics}

$\begin{array}{ll}\text { Owner/Manager: } & \text { Minnesota Department of Transportation } \\ \text { Developer/Designer: } & \text { Minnesota Department of Transportation } \\ \text { Long-Term Steward: } & \text { Minnesota Department of Natural Resources } \\ \text { Federal Regulators: } & \text { U.S. Army Corps of Engineers } \\ & \text { U.S. Fish and Wildlife Service } \\ \text { State Regulator: } & \text { Minnesota Department of Natural Resources }\end{array}$

The management of the area will be turned over to the MnDNR and managed in conjunction with the Staples Wildlife Preserve. The MOA was signed in 1989.

\section{B.5.3.5 Special lssues/Concerns}

None identified. 


\title{
B.6 Otterdam Swamp Wotland Mitigation Bank
}

\section{B.6.1 Conoral Information}

Location: Greensville County, Virginia

Size: $\quad 15$ acres

Owner: Virginia Department of Transportation (VDOT)

Started: 1991

User: $\quad$ Virginia Department of Transportation

Mitigation: In-kind, in-basin

\section{B.6.2 Ecologlcal Charactoristics}

\author{
Wetland System: Palustrine \\ Wetland Type: Herbaceous, scrub-shrub, bottomland hardwood \\ Bank Origin: Creation
}

The Otterdam Swamp Wetland Mitigation Bank is a created wetland adjacent to the Otterdam Swamp. The area was a borrow area for the adjacent highway. The site is gently graded to a small pond in the south-central portion of the site. The pond and surrounding area support healthy vegetation.

The remainder of the site has recovered poorly due to a lack of topsoil and sustained moisture. Much of the shrub-type vegetation has died and will need to be replaced. Flooding and erosion from the stream flowing along the western site boundary have led to bank stabilization with riprap.

\section{B.6.3 Economic Charactoristics}

$\begin{array}{ll}\text { Costs: } & \$ 20,000 / \text { acre } \\ \text { Currency: } & \text { Habitat units } \\ \text { Original Credit: } & 14 \text { acres } \\ \text { Current Credit: } & 0.3 \text { acres }\end{array}$

The VDOT bank uses acreage-based credits. VDOT developments may exchange debits for credits on a 1:1 ratio. VDOT has used bank credits for impacts as small as in the hundreds of square feet. While VDOT believes the bank has reduced costs, the savings are undocumented. 


\section{B.6.4 Management and Regulatory Charactoristics}

$\begin{array}{ll}\text { Owner: } & \text { Virginia Department of Transportation } \\ \text { Operator: } & \text { Virginia Department of Transportation } \\ \text { Long-Term Steward: } & \text { Virginia Department of Transportation } \\ \text { Federal Regulators: } & \text { U.S. Army Corps of Engineers } \\ & \text { U.S. Environmental Protection Agency } \\ & \text { U.S. Fish and Wildlife Service } \\ \text { State Regulators: } & \begin{array}{l}\text { Virginia State Water Control Board } \\ \text { Virginia Game Commission }\end{array}\end{array}$

The VDOT is the sole owner and user of the bank. While no formal procedures are in place, each withdrawal from the bank is approved by a subset of the regulators controlling VDOT development projects. VDOT does not have a formal monitoring program for maintaining the bank. Periodic inspections are performed to ensure that no gross changes in the bank configuration, especially the hydrology, have occurred. VDOT maintains a ledger sheet of both actual drawdowns against the bank and proposed and approved future withdrawals. By maintaining detailed records and tracking future uses, a negative bank balance is maintained.

\section{B.6.5 Spocial lssues}

VDOT has had difficulties in reestablishing scrub-shrub vegetation because of high erosion and decreased precipitation. The lower areas of the site have established vegetation. The transition zone is suffering and will need replanting. Overflow from the adjacent stream has led to placement of riprap, which may decrease total wetland acreage available. The bank, to date, has not been completely ecologically effective. The lack of healthy wetland has also limited economic effectiveness and the management options that the bank was anticipated to provide.

\section{B.7 Winfield Creok Wetland Mitigation Bank}

\section{B.7.1 General Information}

$\begin{array}{ll}\text { Location: } & \text { Wheaton, Illinois (DuPage County) } \\ \text { Size: } & 260 \text { acres (90 acres available for banking) } \\ \text { Hydrologic Basin/Unit: } & \text { West branch of the Duilage River } \\ \text { Started: } & 1990 \\ \text { Date Operational: } & \text { In final planning stage } \\ \text { Owner/Operator: } & \text { Wheaton Park District ind County of DuPage } \\ \text { Users: } & \text { Private developers } \\ \text { Mitigation: } & \text { In-watershed }\end{array}$


The Winfield Creek Wetland Mitigation Bank is a joint city-county venture encompassing three different areas: Community Park (68 acres), Northside Park (69 acres), and Lincoln Marsh Natural Area (125 acres). The planning stage was to be completed 1992, and with construction beginning in 1993.

\section{B.7.2 Ecological Characteristics}

Wetland System: Riverine and isolated Palustrine

Wetland Type: Scrub-shrub, emergent, sedge meadow

Bank Origin: Restoration

Historically, all three areas (Community and Northside Parks and the Lincoln Marsh Natural Area) were wetlands prior to the urban development of the region. During this development, portions of these wetland areas were either filled, channelized, or drained. Water enters these wetland areas from streams and groundwater flows, and leaves via the same route as well as by evapotranspiration. These three sites were determined, in part, as the most suitable for mitigation banking by using a Geographic Information System evaluation that differentiated hydric soils from nonhydric soils and identified hydric soil areas (greater than 10 acres in extent) that were located adjacent to public lands.

Northside Park is essentially open water surrounded by an urban park setting, containing mostly upland Eurasian grasses, shrubs, and tree species (e.g., oaks and maples). The portion of the Lincoln Marsh Natural Area that is proposed for mitigation banking has been channelized. Wildlife species in Community and Northside Parks (e.g., squirrels, Canada goose, carp) have adapted to a suburban environment, while the Lincoln Marsh Natural Area contains a more diverse level of wildlife common to northern Illinois (e.g., red-tailed hawks, muskrat, beaver, Northern water snake).

\section{B.7.3 Economic Charactoristics}

$\begin{array}{ll}\text { Costs: } & \text { Not available } \\ \text { Currency: } & \text { Acreage } \\ \text { Original Credit: } & 90 \text { acres } \\ \text { Current Credit: } & 90 \text { acres }\end{array}$

Bank credits are based on acreage. Credits may be sold, traded, or transferred. Credit ratios will be a minimum of 1.5:1 and a maximum of 3:1. Unit prices for bank credits have yet to be determined. To aid in bank initiation, credit allowances are being considered for developers assisting in construction of the mitigation bank through donation of employee time, materials, and equipment. 


\title{
B.7.4 Managoment and Regulatory Charactoristics
}

\author{
Owner/Manager: Wheaton Park District \\ Developers/Designers: Wheaton Park District \\ DuPage County Department of Environmental Concerns \\ Hey \& Associates \\ Long-Term Steward: Wheaton Park District \\ Federal Regulators: $\quad$ U.S. Army Corps of Engineers \\ U.S. Environmental Protection Agency \\ U.S. Fish and Wildlife Service \\ State Regulators: $\quad$ Illinois Environmental Protection Agency \\ Department of Conservation \\ Department of Transportation Division of Water Resources \\ Other Regulators: $\quad$ Stormwater Management Division of the DuPage County \\ Environmental Concerns Department
}

The use of the mitigation bank is restricted to those persons (companies) planning developments along the West Branch of the DuPage River. The bank will serve multiple functions, including flood control, wildlife habitat, water control, fisheries, recreation, etc. A consultant, Hey \& Associates, was hired in August 1991 to prepare a detailed plan for the design, construction, and management of the bank. The final plan will be prepared on the basis of data concerning the biota, soils, water quality, and hydrologic flows of the area. It will also take cultural aspects, such as archaeological studies, into consideration. The final plan will include information concerning the construction plan, cost estimates (on a per-acre basis), and a long-term monitoring program.

Currently, a Draft Memorandum of Agreement of Wetland Mitigation Banking in Northeastern Illinois is under review. The purpose of the MOA is to allow the state and federal regulatory agencies to issue general permits to establish and operate wetland mitigation banks in the northeastern Illinois area. It would allow banking in cases where development activities would affect small (less than five acres) isolated wetlands or waters in the region. In addition, the use of mitigation banking is required to adhere to the DuPage County Countywide Stormwater and Flood Plain Ordinance (1991).

\section{B.7.5 Special Issues/Concerns}

Because residential and commercial development surround two of the three wetland sites: there is a high possibility of concern from the general public over the loss of existing open water and upland areas. A well-articulated information program may be necessary to overcome public opposition to the project. 


\title{
B.8 Chula Vista Bayfront Marsh Habltat Credit Reserve
}

\section{B.8.1 General Information}

$\begin{array}{ll}\text { Location: } & \text { Chula Vista, California } \\ \text { Size: } & 90.88 \text { acres in three parcels } \\ \text { Hydrologic BasinUnit: } & \text { Not available } \\ \text { Started: } & \text { August } 1990 \\ \text { Date Operational: } & \text { Not available } \\ \text { Owner/Operators: } & \text { Santa Fe Improvement Company } \\ \text { Users: } & \text { Open to both public and private users on the lower west } \\ & \text { coast of California } \\ & \text { (San Diego, Orange, and Los Angeles Counties) } \\ \text { Mitigation: } & \text { In-kind, in-region }\end{array}$

The Chula Vista site consists of 90.88 acres located at three sites: $\mathbf{4 2 . 2}$ acres in the D Street Fill, 31.2 acres on Gunpowder Point, and 17.48 acres in the F and G Street wetlands.

\section{B.8.2 Ecological Charactoristics}

\author{
Wetland System: Estuarine \\ Wetland Type: Intertidal saltmarsh \\ Bank Origin: Removal of historical fill
}

A portion of the area is historical fill over wetlands, and a portion is historical uplands now modified by clearing and development.

\section{B.8.3 Economic Charactoristics}

$\begin{array}{ll}\text { Costs: } & \text { Not available } \\ \text { Currency : } & \text { Acreage } \\ \text { Original Credit. } & \text { Not available } \\ \text { Current Credit: } & \text { Not available }\end{array}$

California currently operates an acreage-based banking system. The coastal commission has used a 1:1 credit to debit ratio in the past. The sale price of the raw land without any enhancement is $\$ 40,000 /$ acre or the appraised value, subject to individual negotiations. The credits are available to any party within San Diego, Orange, and Los Angeles Counties. 


\section{B.8.4 Management and Regulatory Characteristics}

$\begin{array}{ll}\text { Owner/Manager: } & \text { Santa Fe Improvement Company } \\ \text { Developer/Designer: } & \text { Santa Fe Improvement Company } \\ \text { Long-Term Steward: } & \text { Santa Fe Improvement Company } \\ \text { Federal Regulator: } & \text { U.S. Fish and Wildlife Service } \\ \text { State Regulators: } & \text { Not available }\end{array}$

The credits are accumulated by conducting a wildlife enhancement project that has been approved in advance by the USFWS. These projects do not necessarily have to be wetland restoration projects. The Santa Fe Improvement Company, a California corporation, can use the mitigation credits for its own use or sell them to a third party.

\section{B.8.5 Special Issues/Concerns}

None identified.

\section{B.9 San Joaquin Marsh, Orange County}

\section{B.9.1 General Information}

$\begin{array}{ll}\text { Location: } & \text { Irvine, California } \\ \text { Size: } & 200 \text { acres } \\ \text { Hydrologic Basin/Unit: } & \text { Not available } \\ \text { Started: } & 1988 \\ \text { Date Operational: } & \text { Not available } \\ \text { Owner/Operator: } & \text { Irvine Corporation } \\ \text { User: } & \text { Irvine Corporation } \\ \text { Mitigation: } & \text { In-kind or out-of-kind, in-region (Irvine Ranch) }\end{array}$

The San Joaquin Marsh is a 400 -acre remnant freshwater wetland located adjacent to the brackish marshes of the upper Newport Bay Ecological Reserve. Two hundred acres of the marsh are owned by the University of California at Irvine and is managed as a portion of the California Natural Reserve System. The remaining 200 acres is owned by the Irvine Company and is managed as a mitigation bank for Irvine Company use in relation to wetland impacts in the region, particularly those related to the Irvine Ranch developments in Orange County. 


\title{
B.9.2 Ecological Characteristics
}

\author{
Wetland System: Palustrine \\ Wetland Type: Freshwater marsh \\ Bank Origin: Restoration of a forested wetland and supplemental irrigation
}

Freshwater marshes are dominated by cattails (Typha spp.) and bulrush (Scirpus californicus), with remnant saltbush (Atriplex semibaccata) and pickleweed (Salicornia virginica) areas due to salt accumulation.

\section{B.9.3 Economic Characteristics}

$\begin{array}{ll}\text { Costs: } & \$ 15,000-\$ 20,000 / \text { acre } \\ \text { Currency: } & \text { Acreage } \\ \text { Original Credit: } & \text { Not available } \\ \text { Current Credit: } & \text { Not available }\end{array}$

\section{B.9.4 Management and Regulatory Characteristics}

Owner/Manager: Irvine Corporation

Developer/Designer: Irvine Corporation

Long-Term Steward: Irvine Corporation

Federal Regulator: U.S. Fish and Wildlife Service

State Regulator: California Department of Fish and Game

\section{B.9.5 Special Issues/Concerns} marsh.

Recent drought conditions required watering of tree species planted along the edge of the

\section{B.10 Bracut Mitigation Bank}

\section{B.10.1 General Information}

Location: $\quad$ Arcada, California

Size: 13 acres

Hydrologic Basin/Unit: Humboldt Bay

Started: 
Date Operational:

Owner/Operator:

Users:

Mitigation:
1981

California State Coastal Conservancy

Public and private users

In-kind or out-of-kind, in-region

\section{B.10.2 Ecological Characteristics}

Wetland System: Estuarine

Wetland Type: Coastal wetlands

Bank Origin: Removal of historic fill and dike breaching

The Bracut Mitigation Bank contains 6 acres of coastal wetlands dominated by an introduced species, Spartina densiflora (native to Chile), and the native marsh dominant pickleweed (Salicornia virginica). Also included are three rare and endangered marsh species: Point Reyes bird's beak (Cordylanthus maritimus ssp. palustris), Humboldt Bay owl's clover (Orthocarpus castillejoides var. humboldtiensis), and Humboldt Bay gum plant (Grindelia stricta ssp. blakei). The three species are all candidates for federal listing but currently have no state status. Seven acres of riparian and upland habitat dominated by red alder (Alnus rubra) and willow (Salix ssp.) border the marsh. The understory vegetation includes soft rush (Juncus effusus), lady fern (Athyrium filex-femina), and giant horsetail (Equisetum telmateia ssp. braunii).

\section{B.10.3 Economic Characteristics}

$\begin{array}{ll}\text { Cost: } & \$ 27,000 / \text { acre } \\ \text { Currency: } & \text { Acreage } \\ \text { Original Credit: } & 13 \\ \text { Current Credit: } & \text { Exhausted }\end{array}$

The Bracut bank uses acreage units for credit calculation. Under the California Coastal Commission mitigation banking requirements, a minimum of a 1:1 debit to credit ratio is required. Bracut Mitigation Bank has experienced several difficulties that have resulted in the failure of the bank to properly develop into a functioning wetland. Because of the failure, several mitigative operations have occurred to correct the difficulties. These additional activities will increase the costs associated with the site.

The Bracut Marsh Mitigation Bank was initially established to offset the filling of four small (less than two acres) pocket marshes within the industrialized portion of the city of Eureka. Additional credits have been withdrawn for nearby transportation-related improvements. 


\title{
B.10.4 Managoment and Regulatory Characteristics
}

\author{
Owner/Manager: California Coastal Conservancy \\ Developer/Designer: Califormia Coastal Conservancy \\ Long-Term Steward: California Coastal Conservancy \\ Federal Regulators: None \\ State Regulators: California Coastal Commission \\ California Department of Fish \& Game
}

\section{B.10.5 Special Issues/Concerns}

Remnant woody debris from a lumber mill on the site was not removed at the time the site was excavated. This debris has been a continuing problem, as have gravel debris and soil compaction, with the danger of the debris being swept into the estuary if excavated. A revised plan to address these concerns was prepared in 1989 and is currently being implemented. Although the Bracut Marsh has struggled ecologically, the bank has been effective in replacing wetland losses in the county. The management of the bank has remained effective through many plan alterations. The acreage was expensive to create and maintain and has not been cost-effective for the owner.

\section{B.11 North Lake Park Wetland Mitigation Bank, Hillsborough County}

\section{B.11.1 Goneral Information}

$\begin{array}{ll}\text { Location: } & \text { Tampa, Florida } \\ \text { Size: } & 14.8 \text { acres } \\ \text { Hydrologic Basin/Unit: } & \text { Not available } \\ \text { Started: } & 1986 \\ \text { Date Operational: } & \text { Not available } \\ \text { Owner/Operator: } & \text { Hillsborough County } \\ \text { User: } & \text { Hillsborough County Division of Public Works } \\ \text { Mitigation: } & \text { Out-of-kind, in-county }\end{array}$

The North Lake Park wetland mitigation bank was the first bank in Florida. It is one of three banks being put in place by the Hillsborough County Division of Public Works, to offset unavoidable wetland losses due to roadway construction and other public works activities. 


\section{B.11.2 Ecological Characteristics}

Wetland System: Palustrin.

Wetland Type: $\quad$ Forested freshwater wetland

Bank Origin: Weir installation to rehydrate drained area of cypress wetland

This forested freshwater wetland is dominated by pond cypress (Taxodium ascendens). The bank is surrounded by ditches on three sides to prevent the escape of water. The north side of the site is a storm drainage ditch, which appears to have breached the clay layer that was the base for the cypress swamp. The cypress show historic water marks several inches above the present ground level. An attempt to reflood the site has been made by creation of an overflow structure in the stormwater ditch.

\section{B.11.3 Economic Characteristics}

$\begin{array}{ll}\text { Costs: } & \text { Unknown } \\ \text { Currency: } & \text { Acreage } \\ \text { Original Credit: } & \text { Not available } \\ \text { Current Credit: } & \text { Not available } \\ \text { Ratio: } & 1: 1 \text { to 2.5:1 }\end{array}$

\section{B.11.4 Management and Regulatory Characteristics}

$\begin{array}{ll}\text { Owner/Manager: } & \text { Hillsborough County Division of Public Works } \\ \text { Developer/Designer: } & \text { Hillsborough County Division of Public Works } \\ \text { Long-Term Steward: } & \text { Hillsborough County Division of Public Works } \\ \text { Federal Regulators: } & \text { Not available } \\ \text { State Regulators: } & \text { Southwest Florida Water Management District } \\ & \text { Hillsborough County Environmental Protection Commission }\end{array}$

\section{B.11.5 Special Issues/Concerns}

Initially planned as an excavation and planting project, the design was changed early in its implementation when the necessary hydrology could not be guaranteed. The cypress wetland ground elevation was approximately $3 \mathrm{ft}$ higher than the adjacent drainage canal bottom, and the plan became a rehydration project based upon the installing of a broadcasted weir downstream in the drainage canal, with an overflow elevation $1 \mathrm{ft}$ above the swamp floor elevation. A detailed hydrologic/hydraulic study was done to ensure rehydration.

Since construction of the project, the watershed upstream of the site has not contributed flows of sufficient quantities to reach the weir, crest, or overflow into the mitigation area. As a 
result, rehydration of the stressed wetland has not occurred as expected. Drier than normal weather conditions have occurred over the past few years and have led to water-use restrictions throughout the area. These hydraulic phenomena, along with the continued lack of flow in the canal since the construction of the mitigation bank improvements, have led to speculation of additional problems with the bank, such as incorrect design or irreversible water-table lowering due to adjacent well-field pumping, etc.

The continued lack of effectiveness of this project could have severe consequences, as several roadways have already been permitted using credits from this bank. Lack of effectiveness at this bank could require reconstructing the mitigation for all these projects at other locations. Also, it is apparent that the lack of effectiveness of this bank has diminished the enthusiasm initially expressed by various regulatory agencies for the mitigation banking concept and may result in an increase in the level of detail required for analysis of mitigation bank projects beyond that expected for normal mitigation projects. The use of future mitigation bank credits may be delayed for years until project effectiveness is fully obtained.

The project is still under review, and a final solution to the apparent hydraulic problems has not been developed. The potential exists for discharge of highly treated wastewater to the wetland to aid in rehydration, since two, 2-million-gallon storage tanks adjacent to the site could be tapped to provide 0.25 million gallons/day to the wetland.

\section{B.12 References}

Edstrom, O., 1992, Wetlands Creation Plan, Proposed Wetlands Bank, prepared for John Chimento, Little Silver, N.J., prepared by Associated Environmental Applications Inc., Egg Harbor City, N.J.

DuPage County Countywide Stormwater and Floodplain Ordinance, 1991, obtained from DuPage County Stormwater Management Committee and Environmental Concerns Department, Stormwater Management Division, Wheaton, Ill.

Fina LaTerre, Inc., no date, The Delicate Balance, Houma, La., publicity brochure.

Shor:, C., 1988, Mitigation Banking, Biological Report 88(41), prepared for U.S. Fish and Wildlife Service, by National Ecology Research Center, Ft. Collins, Colo.

Soileau, D., 1984, Final Report on the Tenneco LaTerre Corporation Mitigation Banking Proposal, Terrebonne Parish, Louisiana, prepared for U.S. Fish and Wildlife Service, by Division of Ecological Services, Lafayette, La. 
Appendlx C:

Summary of Current Wetland Mitigation Costs 


\section{Appendix C:}

\section{Summary of Current Wotland Mitlgation Costs}

A survey of the oil and gas industry was conducted to gather data on methods and costs for wetland mitigation projects conducted within the past five calendar years. Information gathered for each wetland mitigation project included the location of the wetland impact, size of the impacted area, type of wetland mitigated, type of mitigation involved, areal extent of the mitigation, extent of regulatory involvement, and mitigation costs. Table C. I, at the end of this Appendix, presents details of the mitigation projects.

Separate mitigation cost information was not available for all wetland mitigation projects due to the common practice of utilizing a flat fee per foot of pipeline for gas pipeline projects. Mitigation cost information varied according to location of the wetland impact, type of wetland mitigated, presence of threatened or endangered species, type of mitigation involved, and ratio of the size of the wetland impact to the areal extent of the mitigation. For those projects with available mitigation cost information, wetland impacts were due to pipeline construction, maintenance, or development, and these projects were located throughout the United States. The projects were classified according to four mitigation types: (1) on-site-restoration/revegetation, (2) on-siteimpact minimization, (3) off-site-creation, and (4) off-site-preservation. Preliminary survey results indicate that wetland mitigation projects in the off-site-creation category are the most costly.

The on-site-restoration/revegetation projects varied in size from 0.47 to 25 acres, and their mitigation ratios ranged from $1: 1$ to approximately $1.5: 1$. Eighty percent of the projects in this category were located in either Pennsylvania or New Jersey. Wetland types included bog, marsh, fen, riverine, nontidal stream channels, riparian stream, nontidal riparian, nontidal riparian scrubshrub, nontidal scrub-shrub, scrub-shrub, forested, nontidal forested, nontidal forested riparian, emergent, nontidal emergent marsh, intertidal emergent marsh, and tidal emergent marsh. Mitigation cost per acre of wetland impacted ranged from approximately $\$ 200 /$ acre to approximately $\$ 21,300 /$ acre. The average cost per acre of wetland impacted was $\$ 5,300$ (Bach 1992; Buchanan 1992; Flaim 1992; George 1992; Muller 1992; Wilcher 1992).

On-site-impact minimization projects consisted of impact areas of approximately 2.9 acres in size with a mitigation ratio of $1: 1$. These projects involved freshwater wetlands located in Pennsylvania and New Jersey. The mitigation cost per acre of wetland impacted ranged from approximately $\$ 350 /$ acre to approximately $\$ 5,260$ /acre, with an average cost of approximately $\$ 2,800$ /acre of wetland impacted (Gartman 1992).

The size of the impacted area for off-site-creation projects varied from 0.92 to 7 acres, and their mitigation ratios ranged from 1.2:1 to $2: 1$. These projects were scattered throughout the United States. The wetland types mitigated were forested, low-grade forested, forested/shrub, and palustrine/forested. The mitigation costs per acre of wetland impacted ranged from approximately $\$ 11,800$ to $\$ 50,000 /$ acre. The average cost per acre of wetland impacted was approximately $\$ 24,600$ (Cej 1992; Osborne 1992; Steenberg 1992). 
The off-site-preservation category included only one project, and it had an impacted area of 12.1 acres and a mitigation ratio of 13:1. The wetland was a freshwater, bottomland hardwood swamp located in Florida, and the mitigation cost per acre of wetland impacted was approximately $\$ 5,200$ (Laird 1992).

\section{Roforences}

Bach, T., 1992, personal communication, Natural Gas Pipeline Company of America, Lombard, III.

Buchanan, S., 1992, personal communication, Transcontinental Gas Pipe Line Corporation, Houston, Texas.

Cej, C., 1992, personal communication, National Fuel Gas Distribution Corporation, Buffalo, N.Y.

Flaim, D., 1992, personal communication, Questar Pipeline Company, Salt Lake City, Utah.

Gartman, D., 1992, personal communication, Columbia Gas Disitibution Companies, Wilmington, Del.

George, J., 1992, personal communication, El Paso Natural Gas Company, El Paso, Texas.

Laird, C., 1992, personal communication, Southern Natural Gas Company, Birmingham, Ala.

Muller G., 1992, personal communication, Panhandle Eastern Corporation, Houston, Texas.

Osborne, B., 1992, personal communication, Enron Gas Pipeline Operating Company, Houston, Texas.

Steenberg, J., 1992, personal communication, Enron Gas Pipeline Operating Company, Houston, Texas.

Wilcher, J., 1992, personal communication, Panhandle Eastern Corporation, Houston, Texas. 
TABLE C.1 Summary of Current Wetland Mitigation Costs

\begin{tabular}{|c|c|c|c|c|c|c|c|c|c|}
\hline Compeny & $\begin{array}{l}\text { Type of } \\
\text { Impact }\end{array}$ & $\begin{array}{l}\text { Location of } \\
\text { Impact }\end{array}$ & $\begin{array}{l}\text { Size d } \\
\text { Impact } \\
\text { (acres) }\end{array}$ & $\begin{array}{l}\text { Type of } \\
\text { Wetand }\end{array}$ & $\begin{array}{l}\text { Type of } \\
\text { Mitigation }\end{array}$ & $\begin{array}{l}\text { Extent of } \\
\text { Mitigation } \\
\text { (ecres) }\end{array}$ & $\begin{array}{l}\text { Reguiationy } \\
\text { Apencies: }\end{array}$ & Cod of & Proinet Deses \\
\hline I. On-site & Mitigation: & Aestoration & & & & & & & \\
\hline $\begin{array}{l}\text { Transcon- } \\
\text { tinental Gas } \\
\text { Pipo Lino }\end{array}$ & $\begin{array}{l}\text { Pipelino bop } \\
\text { construction } \\
\text { across Deleware } \\
\text { River }\end{array}$ & $\begin{array}{l}\text { Northamplon } \\
\text { County. Penn. and } \\
\text { Warren County. } \\
\text { NJ. }\end{array}$ & 0.47 & $\begin{array}{l}\text { Nontidal forested } \\
\text { riparian wedlands. } \\
\text { and nontidel } \\
\text { riparian scrib- } \\
\text { shrib and lonesed } \\
\text { wellands }\end{array}$ & $\begin{array}{l}\text { On-sile: } \\
\text { In-tind } \\
\text { restoration/ } \\
\text { reforestation }\end{array}$ & Send" & $\begin{array}{l}\text { USACOE. } \\
\text { USPNS. Pom. } \\
\text { NW. USEA }\end{array}$ & Approx. $\$ 10.000$ & $\begin{array}{l}\text { Posaiby sprims } \\
1994\end{array}$ \\
\hline $\begin{array}{l}\text { Questar } \\
\text { Pipeline }\end{array}$ & Now pipeline & $\begin{array}{l}\text { Scatiored trom } \\
\text { Meea County to } \\
\text { Delores County. } \\
\text { Colo. }\end{array}$ & $\begin{array}{l}\text { Approx. } \\
25\end{array}$ & $\begin{array}{l}\text { Boges or marshes } \\
\text { adjecont to } \\
\text { perennial streams }\end{array}$ & $\begin{array}{l}\text { On-aile: } \\
\text { Powegetation }\end{array}$ & Senen & $\begin{array}{l}\text { usicoe } \\
\text { uspus }\end{array}$ & $\begin{array}{l}\text { Extimened a } \\
\$ 300.000\end{array}$ & $\begin{array}{l}\text { Permining: } 1992 \\
\text { Conatruction: } \\
1993\end{array}$ \\
\hline $\begin{array}{l}\text { Transcon- } \\
\text { tinental Gas } \\
\text { Pipo Lino }\end{array}$ & $\begin{array}{l}\text { Pipelino boop } \\
\text { construction }\end{array}$ & $\begin{array}{l}\text { Middlesex County. } \\
\text { NW. }\end{array}$ & 4.69 & $\begin{array}{l}\text { Nontidal strean } \\
\text { channots. } \\
\text { emergent and } \\
\text { forested wediands }\end{array}$ & 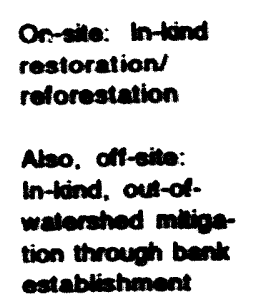 & Semp & $\begin{array}{l}\text { NW. DEPE } \\
\text { NW.DOT }\end{array}$ & $\$ 50.000$ & $\begin{array}{l}\text { Fall } 1991 \text { and } \\
\text { epring } 1992\end{array}$ \\
\hline
\end{tabular}


TABLE C.1 (Cont.)

\begin{tabular}{|c|c|c|c|c|c|c|c|c|c|}
\hline Compeny & $\begin{array}{l}\text { Type of } \\
\text { Impect }\end{array}$ & $\begin{array}{l}\text { Location of } \\
\text { Impact }\end{array}$ & $\begin{array}{l}\text { Size of } \\
\text { Impect } \\
\text { (ecres) }\end{array}$ & $\begin{array}{l}\text { Type of } \\
\text { Wetiend }\end{array}$ & $\begin{array}{l}\text { Typo of } \\
\text { mipation }\end{array}$ & $\begin{array}{l}\text { Extent of } \\
\text { Minigation } \\
\text { (ecrea) }\end{array}$ & Provinory & Cont of & Proinet Dese \\
\hline I. On-sito & Mugation: & Aectoratton (Cont.) & & & & & & & \\
\hline $\begin{array}{l}\text { Netural Gas } \\
\text { Pipelins }\end{array}$ & Now pipeline & lowa & $<1$ & Fen & $\begin{array}{l}\text { On-ale: } \\
\text { Pedioration } \\
\text { revegetation }\end{array}$ & 1.2 & bmong & Approx. $\$ 10,000$ & 1001 \\
\hline $\begin{array}{l}\text { Transcon- } \\
\text { tinented Cas } \\
\text { Pipo Line }\end{array}$ & $\begin{array}{l}\text { Pipalino loop } \\
\text { construction }\end{array}$ & $\begin{array}{l}\text { Clinton County. } \\
\text { Penn. }\end{array}$ & 0.5 & $\begin{array}{l}\text { Nontidal emengent } \\
\text { mareh and sorib- } \\
\text { shrib wetands }\end{array}$ & $\begin{array}{l}\text { On-illo: } \\
\text { In-kind reatoration }\end{array}$ & Seno & Pun DER & $\$ 2,000$ & Fall 1300 \\
\hline $\begin{array}{l}\text { Tranacon- } \\
\text { tinental Gas } \\
\text { Pipo Lne }\end{array}$ & $\begin{array}{l}\text { Pipeline bop } \\
\text { construction }\end{array}$ & $\begin{array}{l}\text { Middbeedx County. } \\
\text { N.J. }\end{array}$ & 1.26 & $\begin{array}{l}\text { Nontidal atream } \\
\text { channels and some } \\
\text { aseociated } \\
\text { emereent wetiends }\end{array}$ & $\begin{array}{l}\text { On-ino: } \\
\text { In-kind restoration }\end{array}$ & Som & NWDEF & $\$ 2,000$ & $\begin{array}{l}\text { Fall } 1991 \text { and } \\
\text { epring } 1992\end{array}$ \\
\hline $\begin{array}{l}\text { Transcon- } \\
\text { tinental Gas } \\
\text { Pipo Line }\end{array}$ & $\begin{array}{l}\text { Pipeline } \\
\text { maintenance }\end{array}$ & $\begin{array}{l}\text { Camden and } \\
\text { Gloucester } \\
\text { Counties, NJ. }\end{array}$ & 1.93 & $\begin{array}{l}\text { Intertidal } \\
\text { emergent marsh } \\
\text { and nontidal } \\
\text { emergent mareh }\end{array}$ & $\begin{array}{l}\text { On-alle: } \\
\text { in-kind restoration }\end{array}$ & Sene & NUDEE & $\$ 2,000$ & Falt 1980 \\
\hline $\begin{array}{l}\text { Transcon- } \\
\text { tinental Gas } \\
\text { Pipe Line }\end{array}$ & $\begin{array}{l}\text { Pipelino bop } \\
\text { construction }\end{array}$ & $\begin{array}{l}\text { Middesex County. } \\
\text { NJ. }\end{array}$ & 7.5 & $\begin{array}{l}\text { Nontidal scrub- } \\
\text { shrib and } \\
\text { cmergent wetlands }\end{array}$ & $\begin{array}{l}\text { On-alle: } \\
\text { In-kind restoration }\end{array}$ & Seme & NLDEFE & Approx. $\$ 5,000$ & $\begin{array}{l}\text { Seplembed } \\
\text { October } 1998\end{array}$ \\
\hline $\begin{array}{l}\text { EPasoo } \\
\text { Natural Gas }\end{array}$ & Now pipeline & $\begin{array}{l}\text { Sen Juan River in } \\
\text { the four corners } \\
\text { area }\end{array}$ & 15 & $\begin{array}{l}\text { Forected area and } \\
\text { adjacent marah }\end{array}$ & $\begin{array}{l}\text { On-ailo: } \\
\text { Pavegation }\end{array}$ & Seme & $\begin{array}{l}\text { LANCOE FERC. } \\
\text { EU }\end{array}$ & $\$ 9.227 .91$ & 1992 \\
\hline $\begin{array}{l}\text { Transcon- } \\
\text { tinental Gas } \\
\text { Pipe Line }\end{array}$ & $\begin{array}{l}\text { Pipeline loop } \\
\text { construction }\end{array}$ & $\begin{array}{l}\text { Northamplon and } \\
\text { Monroe Counties. } \\
\text { Pern. }\end{array}$ & 7.7 & $\begin{array}{l}\text { Nontidel foreated } \\
\text { and emergent } \\
\text { wetlands } \\
\text { aseociated with } \\
\text { various tributaries }\end{array}$ & $\begin{array}{l}\text { On-sile: } \\
\text { In-tind restoration }\end{array}$ & Sano & PundeER & $\$ 5.000$ & $\begin{array}{l}\text { Fall } 1991 \text { and } \\
\text { oummer } 1992\end{array}$ \\
\hline $\begin{array}{l}\text { Transcon- } \\
\text { tinentel Gas } \\
\text { Pipe Line }\end{array}$ & $\begin{array}{l}\text { Pipeline bop } \\
\text { construction }\end{array}$ & $\begin{array}{l}\text { Northampton } \\
\text { County. Pern. }\end{array}$ & 6.3 & $\begin{array}{l}\text { Nontided emergent, } \\
\text { scrib-strub and } \\
\text { foreated wotland } \\
\text { aceociated with } \\
\text { various creaks. } \\
\text { tributaries, and } \\
\text { the Delaware Piver }\end{array}$ & $\begin{array}{l}\text { On-silo: } \\
\text { In-kind restoration }\end{array}$ & Semo & PundEA & $\$ 3,000$ & Fall 1901 \\
\hline
\end{tabular}


TABLE C.1 (Cont.)

\begin{tabular}{|c|c|c|c|c|c|c|c|c|c|}
\hline Company & $\begin{array}{l}\text { Typo of } \\
\text { Impact }\end{array}$ & $\begin{array}{l}\text { Location of } \\
\text { Impact }\end{array}$ & $\begin{array}{l}\text { Size of } \\
\text { Impadt } \\
\text { (acres) }\end{array}$ & $\begin{array}{l}\text { Type of } \\
\text { Wettand }\end{array}$ & $\begin{array}{l}\text { Type of } \\
\text { Maigation }\end{array}$ & $\begin{array}{l}\text { Extent of } \\
\text { Mitigation } \\
\text { (acres) }\end{array}$ & $\begin{array}{l}\text { Pequiatory } \\
\text { Aoncies: }\end{array}$ & $\begin{array}{l}\text { Cost of } \\
\text { Matigation }\end{array}$ & Project Dato \\
\hline On-site & MIt/gation: & Restoration (Cont.) & & & & & & & \\
\hline $\begin{array}{l}\text { Transcon- } \\
\text { tinental Gas } \\
\text { Pipe Lino }\end{array}$ & $\begin{array}{l}\text { Pipelins bop } \\
\text { construction }\end{array}$ & $\begin{array}{l}\text { Gloucester } \\
\text { County, NJ. }\end{array}$ & $\begin{array}{l}\text { Approx. } \\
4.5\end{array}$ & $\begin{array}{l}\text { Tidal and nontidal } \\
\text { emergent marsh } \\
\text { and forestod } \\
\text { wetlands }\end{array}$ & $\begin{array}{l}\text { On-sill: } \\
\text { In-kind restoration }\end{array}$ & Same & $\begin{array}{l}\text { Nh. Bureaus of } \\
\text { Coastal Pesources }\end{array}$ & $\$ 2.000$ & Spring 1909 \\
\hline $\begin{array}{l}\text { Transcon- } \\
\text { tinental Gas } \\
\text { Pipe Line }\end{array}$ & $\begin{array}{l}\text { Pipelino loop } \\
\text { construction }\end{array}$ & $\begin{array}{l}\text { Northampton } \\
\text { County. Penn. }\end{array}$ & 5.86 & $\begin{array}{l}\text { Nontidal emergent. } \\
\text { scrub-shrub and } \\
\text { forested wotlend } \\
\text { associated with } \\
\text { several tributaries }\end{array}$ & $\begin{array}{l}\text { On-sile: } \\
\text { in-tind restoration }\end{array}$ & Semo & Pun DER & $\$ 2.000$ & Fall 1991 \\
\hline $\begin{array}{l}\text { Transcon- } \\
\text { tinental Gas } \\
\text { Pipe Line }\end{array}$ & $\begin{array}{l}\text { Pipelino bop } \\
\text { construction }\end{array}$ & $\begin{array}{l}\text { Gloucester } \\
\text { County. N.J. }\end{array}$ & 21.6 & $\begin{array}{l}\text { Nontidal emergent } \\
\text { marsh. riparian } \\
\text { stream wetands } \\
\text { and some foreated } \\
\text { sreas }\end{array}$ & $\begin{array}{l}\text { On-sillo: } \\
\text { In-kind rectoration }\end{array}$ & Seme & NWDEFE & $\$ 5.000$ & $\begin{array}{l}\text { staned in tan of } \\
\text { 19s0; completed } \\
\text { in tal of } 1901\end{array}$ \\
\hline $\begin{array}{l}\text { Panhandlo } \\
\text { Eastem } \\
\text { Panhandle } \\
\text { Eastem }\end{array}$ & $\begin{array}{l}\text { New pipeline } \\
\text { Pipeline }\end{array}$ & $\begin{array}{l}\text { Morris County. N.J. } \\
\text { Cheder County. } \\
\text { Pern. }\end{array}$ & $\begin{array}{l}\text { Approx. } 3 \\
<5\end{array}$ & $\begin{array}{l}\text { Emergent } \\
\text { Aiverine; small } \\
\text { emergent }\end{array}$ & $\begin{array}{l}\text { On-sile: } \\
\text { Redoration } \\
\text { On-sile: } \\
\text { Reatoration }\end{array}$ & $\begin{array}{l}\text { Seno } \\
\text { Semo }\end{array}$ & 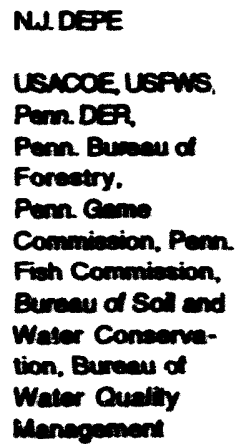 & 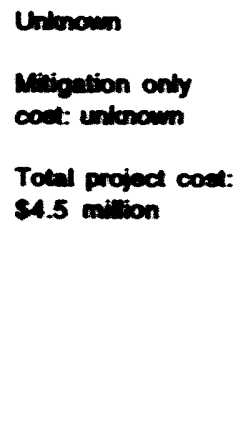 & $\begin{array}{l}1990 \\
1991\end{array}$ \\
\hline
\end{tabular}


TABLE C.1 (Cont.)

\begin{tabular}{|c|c|c|c|c|c|c|c|c|c|}
\hline Company & $\begin{array}{l}\text { Typo of } \\
\text { Impact }\end{array}$ & $\begin{array}{l}\text { Location of } \\
\text { Impact }\end{array}$ & $\begin{array}{l}\text { Size of } \\
\text { Impact } \\
\text { (acres) }\end{array}$ & $\begin{array}{l}\text { Type of } \\
\text { Welland }\end{array}$ & $\begin{array}{l}\text { Type of } \\
\text { Mitigation }\end{array}$ & $\begin{array}{l}\text { Extent of } \\
\text { Miligation } \\
\text { (acres) }\end{array}$ & $\begin{array}{l}\text { Reoulation } \\
\text { Apendece }\end{array}$ & $\begin{array}{l}\text { Coat of } \\
\text { Minigation }\end{array}$ & Projed Date \\
\hline I. On-siro & mirigation: & Nestoration (Cont.) & & & & & & & \\
\hline $\begin{array}{l}\text { Penhandib } \\
\text { Eactom }\end{array}$ & Plpelino & $\begin{array}{l}\text { Cheater County. } \\
\text { Penn. }\end{array}$ & $<5$ & Small emergent & $\begin{array}{l}\text { On-elle: } \\
\text { Peatoration }\end{array}$ & Seme & 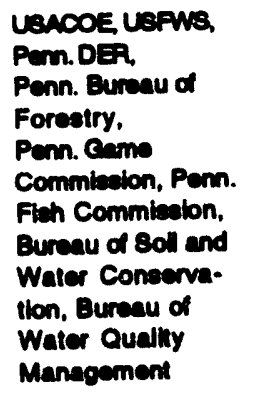 & $\begin{array}{l}\text { Mawigation onty } \\
\text { cont: unknown } \\
\text { Total project cost: } \\
\text { S4 million }\end{array}$ & 1990 \\
\hline II. On-site & Mitigation: & MInimized Impact & & & & & & & \\
\hline Columbia Gas & $\begin{array}{l}\text { Pipeline } \\
\text { construction }\end{array}$ & $\begin{array}{l}\text { Lamington River in } \\
\text { Morris County, N.J. }\end{array}$ & $\begin{array}{l}285 \\
\text { (est.) }\end{array}$ & $\begin{array}{l}\text { Freshwater } \\
\text { wetland }\end{array}$ & $\begin{array}{l}\text { On-she: } \\
\text { Minimized impact }\end{array}$ & Semo & $\begin{array}{l}\text { USPWS, NA. DEPE, } \\
\text { FERC }\end{array}$ & Approx. $\$ 15,000$ & August 1990 \\
\hline Columbia Gas & $\begin{array}{l}\text { Pipelino } \\
\text { construction }\end{array}$ & $\begin{array}{l}\text { Lonape Wetlands } \\
\text { in Choster County, } \\
\text { Penn. }\end{array}$ & $\begin{array}{l}285 \\
(081 .)\end{array}$ & $\begin{array}{l}\text { Freshwater } \\
\text { welland }\end{array}$ & $\begin{array}{l}\text { On-sine: } \\
\text { Minimized impact }\end{array}$ & seme & $\begin{array}{l}\text { USACOE, Punn. } \\
\text { DER FEC }\end{array}$ & $\begin{array}{l}\text { In the hundiede of } \\
\text { dollare }\end{array}$ & November 1987 \\
\hline III. off-site & - Mitigation: & Croation & & & & & & & \\
\hline $\begin{array}{l}\text { Enron Cas } \\
\text { Pipelino }\end{array}$ & New pipelino & $\begin{array}{l}\text { Broward County, } \\
\text { Fa. }\end{array}$ & 0.92 & $\begin{array}{l}\text { Forested/ } \\
\text { shrub wetland }\end{array}$ & $\begin{array}{l}\text { Off-site: } \\
\text { Creation }\end{array}$ & 1.84 & $\begin{array}{l}\text { USACOE, FL DER, } \\
\text { South Fla. Waler } \\
\text { Management } \\
\text { Distrid. Broward } \\
\text { County } \\
\text { Environmental } \\
\text { Quality Control } \\
\text { Board }\end{array}$ & $\$ 50,000 /$ acre & $\begin{array}{l}\text { Staned in 1901: } \\
\text { miltigation } \\
\text { ongoing }\end{array}$ \\
\hline $\begin{array}{l}\text { Enron Gas } \\
\text { Pipelline }\end{array}$ & Pipelino & $\begin{array}{l}\text { Jo Davies County. } \\
\text { III. }\end{array}$ & 7 & $\begin{array}{l}\text { Low-grado, } \\
\text { forested wolland } \\
\text { along Misesiseippi } \\
\text { River }\end{array}$ & $\begin{array}{l}\text { Off-site: } \\
\text { Creatlon of bird } \\
\text { mating habliat }\end{array}$ & $9.5 \cdot 10$ & $\begin{array}{l}\text { USACOE, LSPWS, } \\
\text { FERC, III. state } \\
\text { agendice }\end{array}$ & $\begin{array}{l}\text { Eatimated at } \\
\$ 80,000 \\
\$ 90,000\end{array}$ & $\begin{array}{l}\text { 1991-February } \\
1992\end{array}$ \\
\hline
\end{tabular}


TABLE C.1 (Cont.)

\begin{tabular}{|c|c|c|c|c|c|c|c|c|}
\hline $\begin{array}{l}\text { Type of } \\
\text { Impact }\end{array}$ & $\begin{array}{l}\text { Location of } \\
\text { Impact }\end{array}$ & $\begin{array}{l}\text { Size of } \\
\text { Impact } \\
\text { (acres) }\end{array}$ & $\begin{array}{l}\text { Type of } \\
\text { Wotland }\end{array}$ & $\begin{array}{l}\text { Type of } \\
\text { Mitigation }\end{array}$ & $\begin{array}{l}\text { Extent of } \\
\text { Mitigation } \\
\text { (acres) }\end{array}$ & $\begin{array}{l}\text { Regulatory } \\
\text { Agencies" }\end{array}$ & $\begin{array}{l}\text { Cost of } \\
\text { Mitigation }\end{array}$ & Project Date \\
\hline Off-site Mitigation: & Creation (Cont.) & & & & & & & \\
\hline $\begin{array}{l}\text { National Fuel Development } \\
\text { Gas } \\
\text { Distribution }\end{array}$ & Erio County, N.Y. & $\begin{array}{l}\text { Approx. } \\
4.24\end{array}$ & $\begin{array}{l}\text { Palustrine. } \\
\text { forested wolland }\end{array}$ & $\begin{array}{l}\text { Off-site: } \\
\text { Creation }\end{array}$ & 5 & $\begin{array}{l}\text { USEPA USACOE } \\
\text { USFWS, N.Y. DEC. } \\
\text { Town of Orchard } \\
\text { Park. Town of } \\
\text { Clarence }\end{array}$ & $\begin{array}{l}\text { Estimated at } \\
\$ 50,000\end{array}$ & $\begin{array}{l}\text { Impact: 1989; } \\
\text { mitigation is } \\
\text { ongoing }\end{array}$ \\
\hline Iv. Off-site Mirigation: & Proservation & & & & & & & \\
\hline $\begin{array}{l}\text { Southem New pipeline } \\
\text { Natural Cas }\end{array}$ & $\begin{array}{l}\text { Sumance, Baker, } \\
\text { Nassau and } \\
\text { Columbia } \\
\text { Counties, Fla. }\end{array}$ & 12.09 & $\begin{array}{l}\text { Freshwater } \\
\text { bottomland } \\
\text { hardwood swamps } \\
\text { (cypress) }\end{array}$ & $\begin{array}{l}\text { Off-site; } \\
\text { Preservation }\end{array}$ & Approx. 157 & $\begin{array}{l}\text { USACOE, Fa. DER, } \\
\text { Suwaneo Water } \\
\text { Management } \\
\text { District, St. Johns } \\
\text { Water } \\
\text { Management } \\
\text { District }\end{array}$ & $\$ 63.000$ & $\begin{array}{l}\text { Started in 1888; } \\
\text { compliance b } \\
\text { ongoing }\end{array}$ \\
\hline v. Other & & & & & & & & \\
\hline $\begin{array}{l}\text { Southerm } \\
\text { Natural Gas }\end{array}$ & South Louisiana & 38 & $\begin{array}{l}\text { Salk marsh to } \\
\text { fresh marsh }\end{array}$ & $\begin{array}{l}\text { Not yot } \\
\text { determined: } \\
\text { Probably on-site } \\
\text { and off-site }\end{array}$ & $\begin{array}{l}\text { Estimated at } \\
250\end{array}$ & $\begin{array}{l}\text { USACOE USFWS, } \\
\text { La. DNP, La. DEQ. } \\
\text { FERC, Netional } \\
\text { Marine Fisheries } \\
\text { Service }\end{array}$ & $\begin{array}{l}\text { Estimated at } \$ 2 . \\
2.5 \text { million }\end{array}$ & Ongoing \\
\hline
\end{tabular}

- Abbreviations: USACOE, U.S. Army Corps of Engineers; USFWS, U.S. Fish and Widitite Service; USEPA. U.S. Environmental Protection Agency; DER, Department of Environmental Reecources:

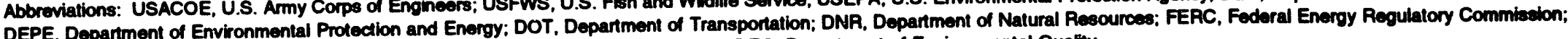
BIM Bureau of Land Management; DEC. Department of Environmental Conservation; DEQ. Department of Environmental Quality.

- Same $=$ same acreage as the area impacted. 

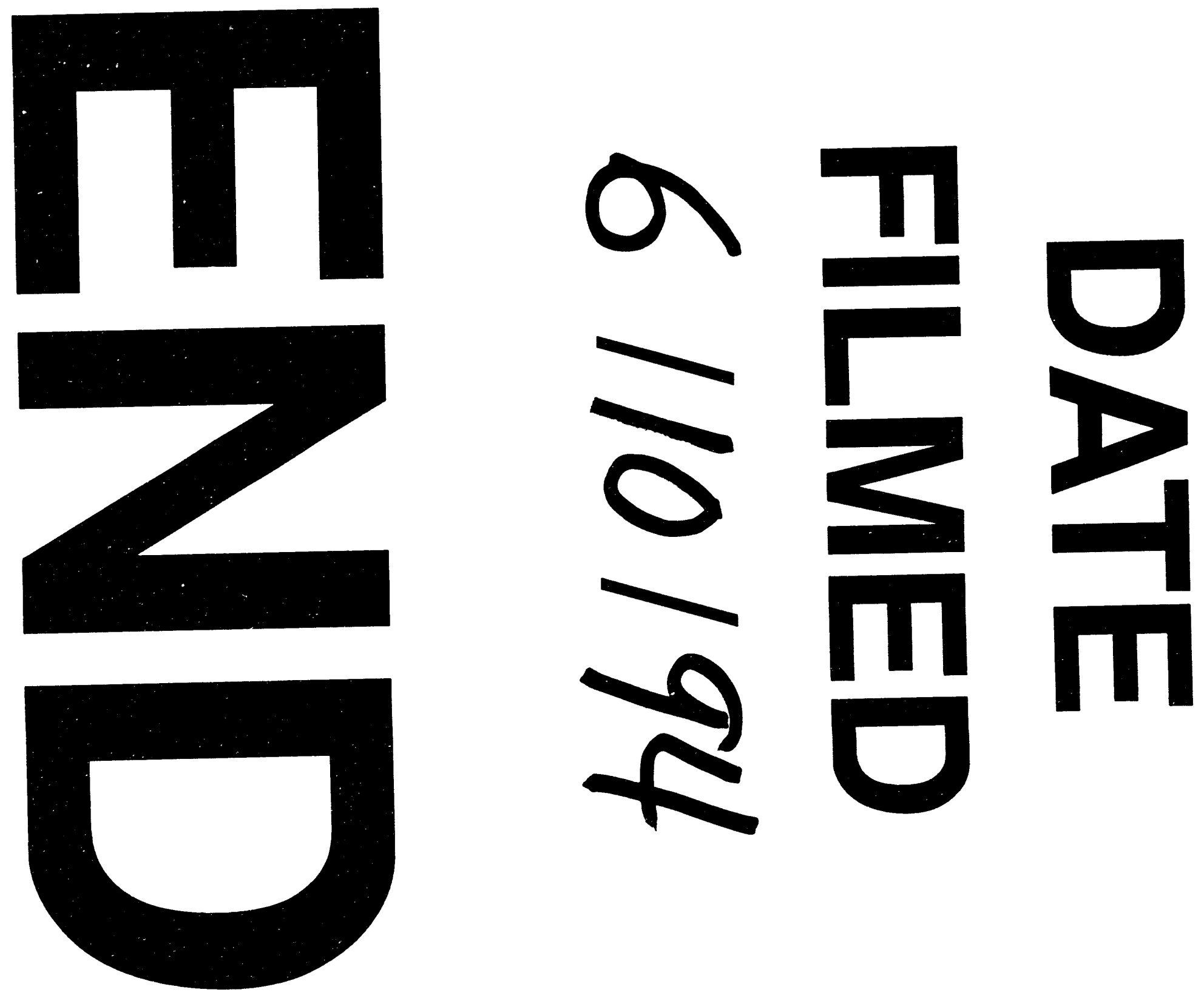
